ANA LUISA ARANHA

\title{
AVALIAÇÃO LABORATORIAL E DE CAMPO DA TECNOLOGIA DE RECICLAGEM DE BASE COM CIMENTO PARA A REABILITAÇÃO DE PAVIMENTOS
}

Dissertação apresentada à Escola Politécnica da Universidade de São Paulo para obtenção do título de Mestre em Engenharia.

São Paulo 


\title{
AVALIAÇÃO LABORATORIAL E DE CAMPO DA TECNOLOGIA DE RECICLAGEM DE BASE COM CIMENTO PARA A REABILITAÇÃO DE PAVIMENTOS
}

\author{
Dissertação apresentada à Escola \\ Politécnica da Universidade de São Paulo \\ para obtenção do título de Mestre em \\ Engenharia. \\ Área de Concentração: \\ Engenharia de Transportes \\ Orientadora: Profa. Dra. Kamilla Lima \\ Vasconcelos
}


Este exemplar foi revisado e alterado em relação à versão original, sob responsabilidade única do autor e com a anuência de seu orientador.

São Paulo, de fevereiro de 2013.

Assinatura do autor

Assinatura do orientador

FICHA CATALOGRÁFICA

Aranha, Ana Luisa

Avaliação laboratorial e em campo da tecnologia de reciclagem de base com cimento para a reabilitação de pavimentos / A.L. Aranha. -- ed.rev. -- São Paulo, 2013. $127 \mathrm{p}$.

Dissertação (Mestrado) - Escola Politécnica da Universidade de São Paulo. Departamento de Engenharia de Transportes.

1. Pavimentação (Reabilitação) 2. Cimento 3. Reciclagem 4. Avaliação laboratorial 5. Avaliação em campo l. Universidade de São Paulo. Escola Politécnica. Departamento de Engenharia de Transportes II. t. 
Aos meus pais,

que tornaram tudo possível. 


\section{AGRADECIMENTOS}

Aos meus pais Walkiria e Domingos, pelo amor, ensinamentos e incentivos.

Aos meus irmãos André e Gabriela, pelos bons e maus exemplos.

Aos meus sobrinhos Neto, Carol, Camila, Andrézinho e Pedro, por todos os momentos felizes.

À minha orientadora Professora Kamilla Vasconcelos, pelo o aprendizado, carinho, dedicação e paciência.

À Professora. Liedi Bernucci por toda a disposição em ensinar, orientar e aconselhar.

À minha grande amiga Amanda Marcandali, por tantas contribuições positivas a esse trabalho.

Aos alunos de Iniciação Científica Pedro, Letícia, Caio e Edigar, que fizeram parte desse projeto.

A toda a equipe do LTP, em especial os laboratoristas Erasmo e Cleyton e os técnicos Kendi, Robson e Vanderley, por toda ajuda na realização dos ensaios.

À amiga Diomária dos Santos, peça fundamental no funcionamento do LTP.

À Renata Monte, pela disponibilidade e prontidão para a realização de ensaios no Laboratório do PCC.

Às amigas Larissa e Tathiane pelos momentos de descontração e os de silêncio.

Ao Grupo OHL Brasil, pela parceria na realização desta pesquisa.

À ANTT, por possibilitar a realização de pesquisas práticas em parceria com a Universidade.

Ao CNPq, pela bolsa de mestrado. 


\section{RESUMO}

Esta pesquisa avaliou a técnica de reciclagem de solo-agregado com adição de cimento para a reconstrução de pavimentos asfálticos deteriorados. A técnica utilizada consiste da adição de cimento a uma base de solo-brita, configurando assim uma base cimentada de solo-brita-cimento. A utilização de agregados reciclados na pavimentação é prática crescente no Brasil e no mundo, recebendo incentivos públicos e sociais, além de representar grandes benefícios ambientais associados à redução do bota-fora, da exploração de recursos naturais e transporte de insumos. Tais agregados apresentam características únicas, inerentes a sua origem e utilização prévia, portanto necessitam de estudos quando de sua utilização em qualquer camada de pavimento. Os materiais utilizados nesta pesquisa são provenientes da base de solo-brita existente na rodovia Fernão Dias. A esses materiais foi adicionado cimento Portland para compor novos materiais de sub-base reciclada. Por apresentar função estrutural bastante significativa no sistema de camadas do pavimento, a camada cimentada necessita de uma criteriosa e abrangente caracterização mecânica. Esse estudo foi dividido em duas frentes distintas de avaliação: estudos laboratoriais e estudos de campo. Nos estudos laboratoriais foram testadas cinco misturas de material reciclado com cimento, com variações do tipo de materiais reciclado, teor de cimento e energia de compactação. Avaliam-se também diferentes métodos de ensaio, comparando resultados obtidos para procedimento de ensaio de concretos e argamassas, e de materiais granulares. Todas as variáveis testadas em laboratório apresentaram influência no comportamento mecânico das misturas cimentadas. Os estudos de campo consistem da construção e do monitoramento estrutural do trecho experimental, além de ensaios mecânicos em corpos de prova extraídos de pista. Foi possível avaliar a evolução da estrutura do pavimento no período de um ano e fazer a verificação dos parâmetros de rigidez in situ e em laboratório.

Palavras-chave: Reabilitação de pavimentos. Reciclagem com cimento. Trecho experimental. Estudo laboratorial. 


\begin{abstract}
This research evaluated the soil-aggregate recycling with cement, soil-aggregatecement mixtures, as a cementitious subbase solution for pavement rehabilitation. The use of recycled aggregates as paving material is an increasing practice in Brazil and abroad, receiving public and social incentives, as well as representing major environmental benefits associated with the reuse and conservation of natural resources, and reduction of the materials transportation costs. Such aggregates have unique characteristics inherent to their origin and previous use; therefore it should be extensively evaluated whenever used in any pavement layer. The materials selected to this study were collected from the base course of Fernão Dias Highway. To these materials, Portland cement was added, in order to establish new materials to the recycled subbase. Since it presents a very significant structural function in the pavement layers system, the cement treated base requires a careful and comprehensive mechanical characterization. This research was divided in laboratory and field evaluation. Five recycled mixtures with cement were studied in laboratory, varying: the recycled aggregate material, the cement percentage added to the mixture, and the energy compaction. Different laboratory standard procedures, applied for concrete and granular material, were also studied. All the variables investigated influenced the mechanical behavior of the recycled cementitious mixtures. The field study consisted of the construction and structural monitoring of an experimental test site comprised of three segments (varying the thickness of the recycled subbase layer), and also laboratory mechanical tests of field cores. The results have shown the structural evaluation of the pavement along one year, and also stiffness parameters measured in situ from the field cores.
\end{abstract}

Key Words: Pavement Rehabilitation. Recycling with Cement. Experimental Test Site. Laboratory Evaluation. 


\section{LISTA DE FIGURAS}

Figura 1 - Evolução da condição do pavimento (adaptado de ARRA, 2001) ...........21

Figura 2 - Consumos de material (Adaptado de www.cement.org) .........................22

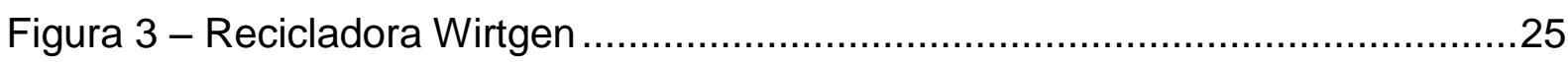

Figura 4 - Bits misturadores/fresadoras (adaptado de www.wirtgenbrasil.com.br) ...26

Figura 5 - Horizontes de formação dos solos (Fonte: Macedo, 2004) .......................30

Figura 6 - Processo de hidratação do cimento (adaptado de Mehta, 2008) ..............36

Figura 7 - Pavimento flexível (Adaptado de Balbo, 2007) ....................................... 38

Figura 8 - Pavimento rígido (Adaptado de Balbo, 2007) .........................................38

Figura 9 - Pavimento semirrígido (Adaptado de Balbo, 2007) .................................39

Figura 10 - Ensaio de granulometria ................................................................. 47

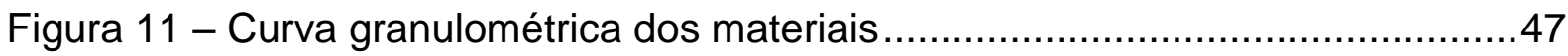

Figura 12 - Distribuição granulométrica para misturas solo-brita-cimento .................48

Figura 13 - Distribuição granulométrica para misturas solo-cimento (DER/SP ET-DE-

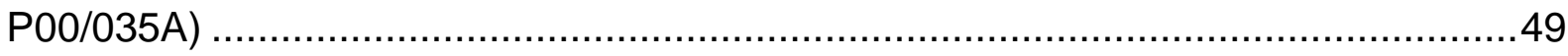

Figura 14 - Ensaio de contração (metodologia MCT) …......................................50

Figura 15 - Ensaio de penetração (metodologia MCT) …….................................50

Figura 16 - Curva de compactação - Variação do material.......................................53

Figura 17 - Curva de compactação - Variação do teor de cimento ...........................53

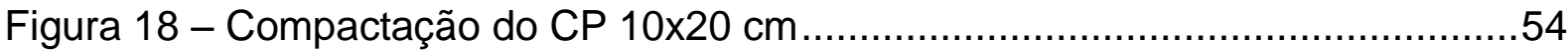

Figura 19 - Extração e armazenamento do CP 10x20 cm ...................................55

Figura 20 - Comparativo entre métodos de ensaio de RT ....................................56

Figura 21 - Comparativo entre métodos de ensaio de RC .....................................58

Figura 22 - Curva tensão $x$ deformação para CPs com 7 dias de cura ....................59

Figura 23 - Curva tensão $x$ deformação para CPs com 28 dias de cura ...................60

Figura 24 - Ensaio de MR - Aplicação de Carga (Adaptado da AASHTO T 307) ....61

Figura 25 - Ensaio de ME - Aplicação de Carga (Adaptado da NBR 8522) ..............61

Figura 26 - Ciclo de aplicação de cargas no ensaio de módulo de resiliência ..........62

Figura 27 - Ciclo de aplicação de cargas no ensaio de módulo de elasticidade ......63

Figura 28 - Ciclos de carregamento e descarregamento - Módulo de resiliência ....64

Figura 29 - Ciclos de carregamento e descarregamento - Módulo de elasticidade .64

Figura 30 - Resultados da comparação entre MR e ME........................................65

Figura 31 - Instrumentação no ensaio de MR........................................................66 
Figura 32 - Instrumentação no ensaio de ME. .66

Figura 33 - Resultados de resistência à tração - Variação de materiais . .68

Figura 34 - Resultados de resistência à compressão - Variação de materiais ........70

Figura 35 - Resultados de resistência à tração - Variação de teores de cimento ....72

Figura 36 - Resultados de resistência à compressão - Variação de teores de cimento.

Figura 37 - Resultados de módulo de resiliência - Variação de teores de cimento .76 Figura 38 - Resultados de módulo de resiliência - 5\% de Cimento - Aos 7 e 28 dias de cura

Figura 39 - Resultados de módulo de resiliência - 6\% de Cimento - Aos 7 e 28 dias de cura

Figura 40 - Resultados de módulo de resiliência - 7\% de Cimento - Aos 7 e 28 dias de cura .78

Figura 41 - Resultados de módulo de resiliência - Aos 28 dias de cura .78

Figura 42 - Resultados de resistência à tração - Variação da energia de compactação

Figura 43 - Resultados de resistência à compressão - Variação da energia de compactação

Figura 44 - Ilustração do plano de compactação e do plano de ensaio no RT e na RCS .82

Figura 45 - Avaliação da cura do material cimentado .83

Figura 46 - Localização do trecho experimental .... .85

Figura 47 - Estrutura do pavimento deteriorado .86

Figura 48 - Variação estrutural no trecho experimental .87

Figura 49 - Material proveniente da fresagem (RAP) .89

Figura 50 - Trecho após fresagem .89

Figura 51 - Distribuição do cimento no trecho experimental. .90

Figura 52 - Trecho após a distribuição do cimento .90

Figura 53 - Distribuição da água pelo equipamento reciclador .90

Figura 54 - Painel de controle do equipamento reciclador .90

Figura 55 - Equipamento reciclador. .91

Figura 56 - Medição da profundidade da camada .92

Figura 57 - Compactação da camada reciclada com cimento .92

Figura 58 - Finalização da camada reciclada com cimento 
Figura 59 - Controle de execução da obra .92

Figura 60 - Primeiro levantamento deflectométrico - Segmento de $20 \mathrm{~cm}$ de camada reciclada com cimento

Figura 61 - Primeiro levantamento deflectométrico - Segmento de $25 \mathrm{~cm}$ de camada reciclada com cimento

Figura 62 - Primeiro levantamento deflectométrico - Segmento de $30 \mathrm{~cm}$ de camada reciclada com cimento .95

Figura 63 - Bacias de deflexão médias - Primeiro levantamento deflectométrico....96

Figura 64 - Segundo levantamento deflectométrico -

Figura 65 - Segundo levantamento deflectométrico - Segmento de $25 \mathrm{~cm}$ de camada reciclada com cimento

Figura 66 - Segundo levantamento deflectométrico - Segmento de $30 \mathrm{~cm}$ de camada reciclada com cimento 98

Figura 67 - Bacias de deflexão médias - Todos os levantamentos. 99

Figura 68 - Retroanálise da bacia média - 1ํ Levantamento - Segmento de $20 \mathrm{~cm}$ de camada reciclada com cimento

Figura 69 - Retroanálise da bacia média - 20 Levantamento - Segmento de $20 \mathrm{~cm}$ de camada reciclada com cimento 102

Figura 70 - Retroanálise da bacia média - 1ํ Levantamento - Segmento de $25 \mathrm{~cm}$ de camada reciclada com cimento 103

Figura 71 - Retroanálise da bacia média - $2^{\circ}$ Levantamento - Segmento de $25 \mathrm{~cm}$ de camada reciclada com cimento 103

Figura 72 - Retroanálise da bacia média - 1ํ Levantamento - Segmento de $30 \mathrm{~cm}$ de camada reciclada com cimento 105

Figura 73 - Retroanálise da bacia média - 2ํㅡㄴ Levantamento - Segmento de $30 \mathrm{~cm}$ de camada reciclada com cimento 105

Figura 74 - Extração de corpos de prova em campo 107

Figura 75 - Corpo de prova com altura insuficente e segregado 108

Figura 76 - llustração do ensaio de ultrassom 108

Figura 77 - llustração do ensaio de módulo de resiliência triaxial 110

Figura 78 - Resultado de ensaio de MR triaxial - Camada de $25 \mathrm{~cm}$ de camada reciclada com cimento

Figura 79 - Resultado de ensaio de MR triaxial - Camada de $30 \mathrm{~cm}$ de camada reciclada com cimento 
Figura 80 - llustração do ensaio de módulo de elasticidade.................................112

Figura 81 - Módulo de resiliência vs. módulo de elasticidade ..............................113 


\section{LISTA DE TABELAS}

Tabela 1 - Nomenclatura dos horizontes de formação dos solos ...........................30

Tabela 2 - Resultados de estudos contemplando misturas cimentadas ....................33

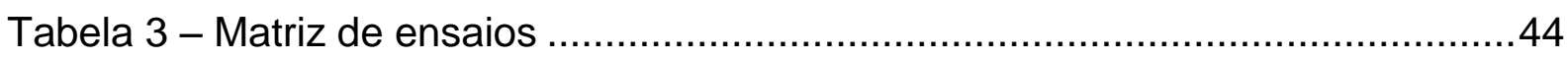

Tabela 4 - Resultados da classificação do solo ………......................................50

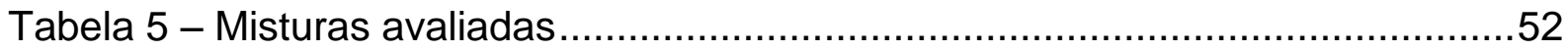

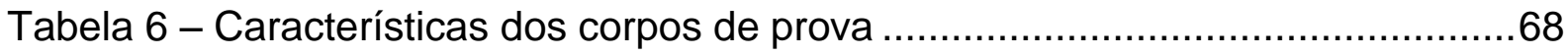

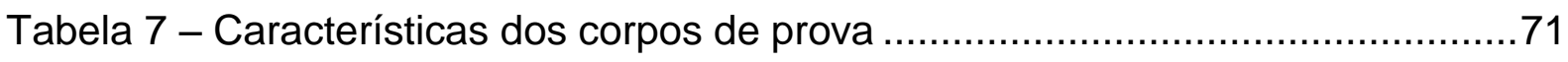

Tabela 8 - Relação água/cimento das misturas ensaiadas .....................................73

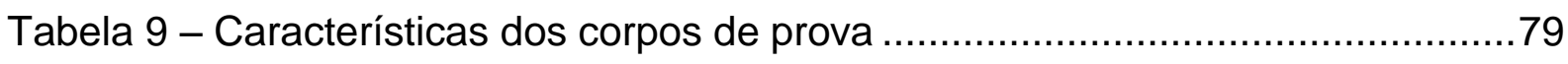

Tabela 10 - Características dos corpos de prova ................................................ 82

Tabela 11 - Materiais encontrados na rodovia Fernão Dias ........................................ 86

Tabela 12 - Resultados de MR por retroanálise $(20 \mathrm{~cm})$...................................101

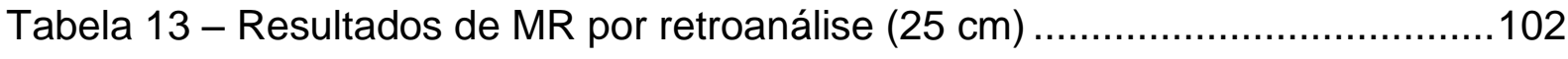

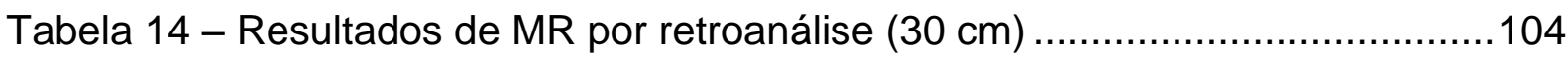

Tabela 15 - Resultados dos ensaios de ultrassom ..............................................109

Tabela 16 - Resultados de ensaio de módulo de resiliência triaxial .......................110

Tabela 17 - Resultados de ensaio de módulo de elasticidade ................................113

Tabela 18 - Resultados de ensaio de resistência à compressão............................114 


\section{LISTA DE ABREVIATURAS E SIGLAS}

AASHTO - American Association of State Highway and Transportation Officials ABNT - Associação Brasileira de Normas Técnicas

ARRA - Asphalt Recycling \& Reclaiming Association

ASTM - American Society for Testing and Materials

BGS - Brita Graduada Simples

CNT - Confederação Nacional dos Transportes

CONAMA - Conselho Nacional do Meio Ambiente

Do - Deflexão Máxima

DER - Departamento de Estradas de Rodagem

FDR - Full Depth Reclamation

FHWA - Federal Highway Administration

FWD - Falling Weight Deflectometer

ME - Módulo de Elasticidade

MR - Módulo de Resiliência

PIARC - World Road Association

PMSP - Prefeitura Municipal de São Paulo

RAP - Reclaimed Asphalt Pavement

RC - Resistência à Compressão

RT - Resistência à Tração 


\section{SUMÁRIO}

1 INTRODUÇÃO

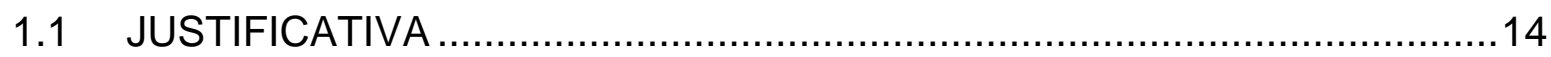

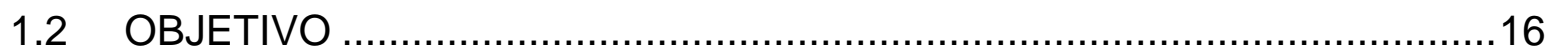

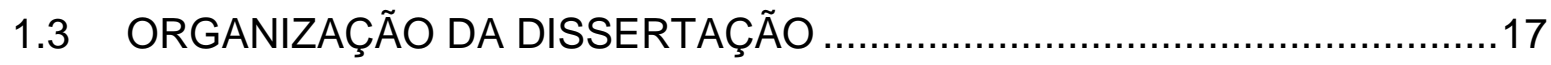

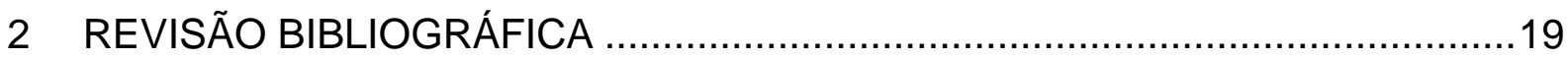

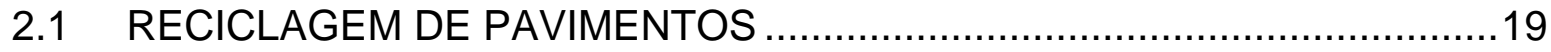

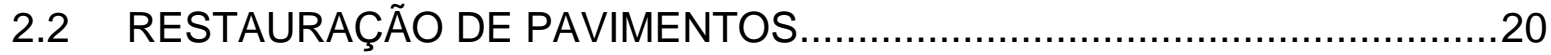

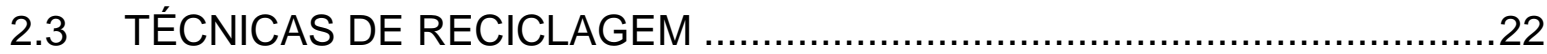

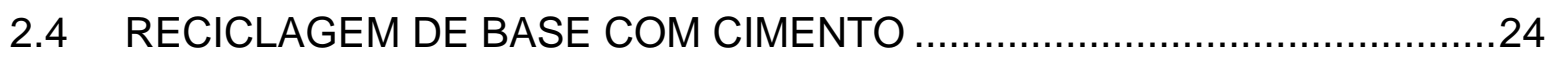

2.5 CARACTERÍSTICAS DE MISTURA CIMENTADA RECICLADA ................28

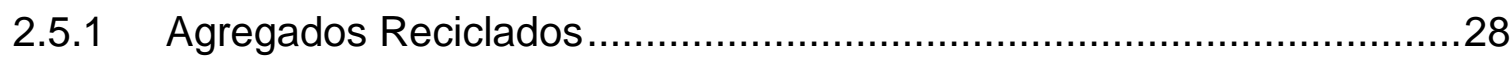

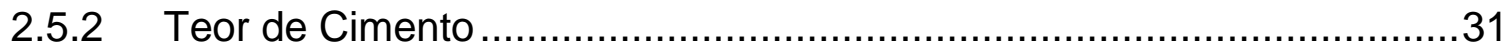

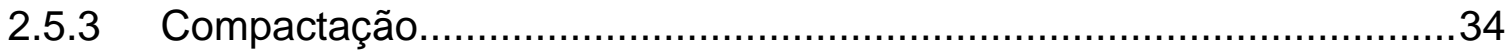

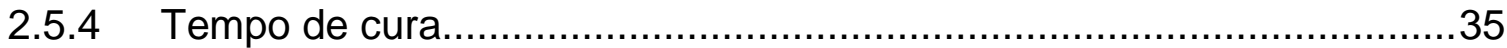

2.6 A MISTURA CIMENTADA NA ESTRUTURA DO PAVIMENTO ...................37

2.7 DESEMPENHO DO PAVIMENTO SEMIRÍGIDO .......................................40

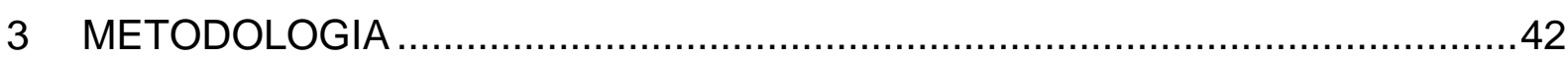

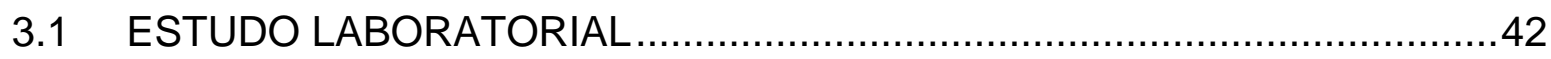

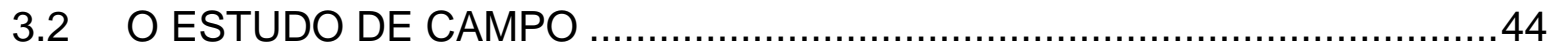

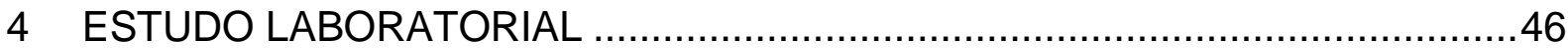

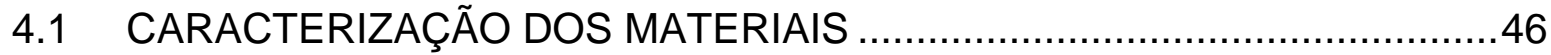

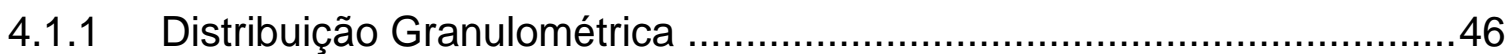

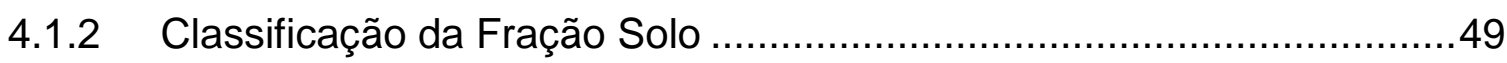

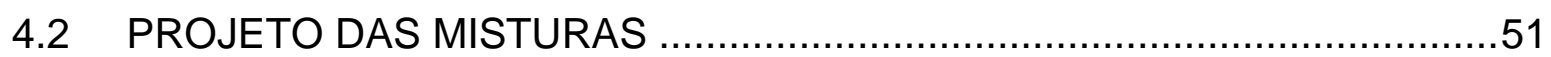

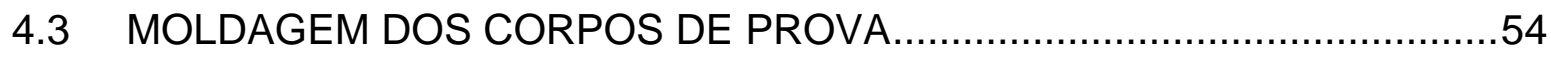

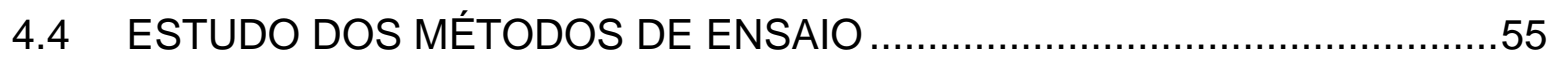

4.4.1 Ensaio de Resistência à Tração por Compressão Diametral .................55

4.4.2 Ensaio de Resistência à Compressão ………..................................57

4.4.3 Ensaio de Módulo de Resiliência e Módulo de Elasticidade ....................60

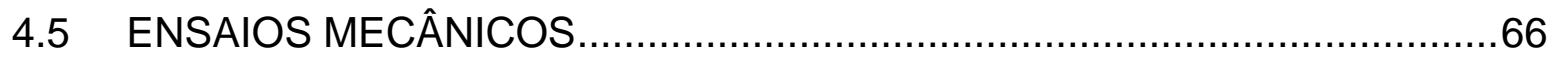

4.5.1 Comparação entre Materiais Reciclados ……………........................68

4.5.2 Comparação entre Teores de Cimento..............................................

4.5.3 Comparação entre Energias de Compactação ......................................79 


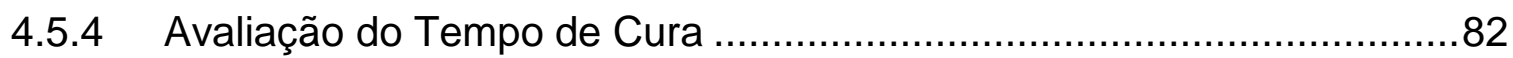

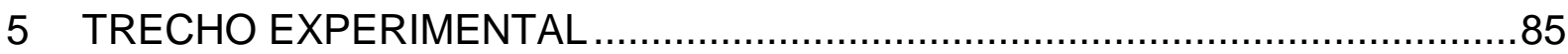

5.1 CONSTRUÇÃO DO TRECHO EXPERIMENTAL................................... 88

5.2 MONITORAMENTO DO TRECHO EXPERIMENTAL ..................................

5.2.1 Primeiro Levantamento Deflectométrico ............................................93

5.2.2 Segundo Levantamento Deflectométrico ............................................96

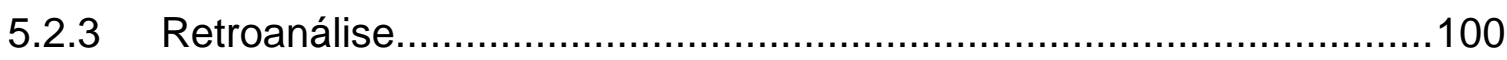

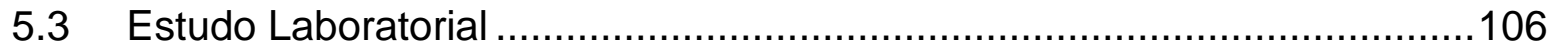

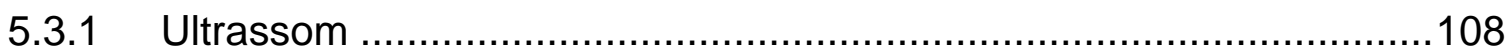

5.3.2 Módulo de Resiliência Triaxial ......................................................109

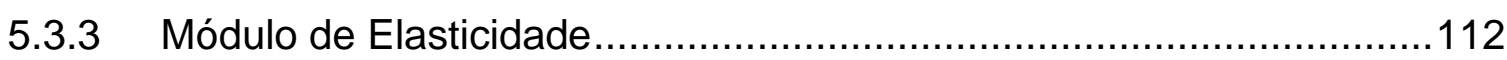

5.3.4 Módulo de Resiliência versus Módulo de Elasticidade .......................113

5.3.5 Resistência à Compressão Simples .................................................114

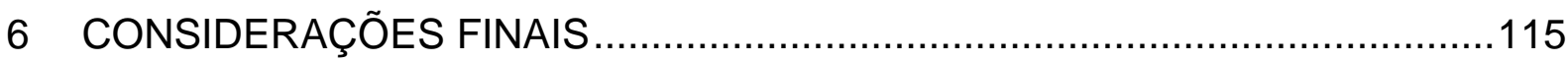

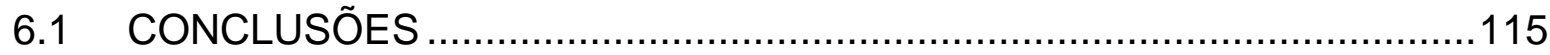

6.2 SUGESTÕES PARA PESQUISAS FUTURAS ........................................117

7 REFERÊNCIAS BIBLIOGRÁFICAS …...................................................118 


\section{INTRODUÇÃO}

\subsection{JUSTIFICATIVA}

A malha rodoviária de um país é muito representativa de suas condições de desenvolvimento, além de ser um fator decisivo para que esse aconteça. No Brasil, $58 \%$ do transporte de cargas é feito pelo modal rodoviário (CNT, 2006) tornando, portanto, a qualidade das rodovias importante para o desenvolvimento econômico do país.

Para a manutenção do nível de serviço das rodovias, periodicamente elas passam por processos de restauração que normalmente consistem da aplicação de novas camadas de revestimento asfáltico, contemplando ou não a retirada da camada deteriorada (ARRA, 2001). Essa prática acarreta em consumo de matéria prima e elevação do greide do pavimento, resultando em elevados impactos ambientais.

A utilização de agregados novos em processos de restauração inicia um ciclo de exploração de jazidas, produção e transporte desse material, que gera não só impactos ambientais como financeiros. Estudos apontam custos entre 50 e $60 \%$ superiores para processos de restauração que não contemplam nenhum tipo de reciclagem (SALOMON; NEWCOMB, 2000).

Com o objetivo de redução dos impactos ambientais causados pela extração e pelo transporte de matérias primas surgem incentivos governamentais para a utilização de materiais reciclados nas obras de infraestrutura rodoviária (SCHIMMOLLER et al., 2000). Essas medidas, somadas à redução de custos nas obras, fazem com que os órgãos federais, estaduais e municipais, além das concessionárias, adotem cada vez mais a reciclagem como solução na restauração de pavimentos danificados, sem sacrificar a qualidade dos materiais empregados, nem os resultados de durabilidade esperados. 
Nesse contexto, pesquisas voltadas ao reuso de materiais vêm sendo cada vez mais desenvolvidas, agregando valor a esses materiais que, de outra forma, seriam descartados.

As pesquisas e a utilização dos materiais provenientes de pavimentos degradados se intensificaram na década de 1970 em função da crise econômica e de petróleo (MILLER et al., 2006). Atualmente, a legislação da prefeitura de São Paulo (PMSP) prevê a obrigatoriedade do reuso dos materiais do pavimento deteriorado em sua restauração.

O processo mais comum de reciclagem contempla a fresagem da camada de rolamento e a utilização do material resultante como agregados para a composição de novas misturas. Contudo, pavimentos com problemas estruturais graves necessitam de uma intervenção mais profunda, chegando às camadas subjacentes à camada de rolamento.

A reciclagem de base promove uma melhoria considerável às condições estruturais do pavimento, uma vez que a reconstrução atinge um maior número de camadas. Quando se adiciona cimento em uma base granular, o ganho estrutural é ainda maior, já que o pavimento passa de flexível a semirrígido (YODER; WITCZAK, 1975).

A presença de uma camada cimentada, em substituição à uma camada granular, na estrutura do pavimento reduz a espessura da camada asfáltica, pois sua elevada rigidez faz com que a camada superior passe a trabalhar principalmente à compressão. Considerando-se que as tensões de tração são as críticas para misturas asfálticas, sua redução leva e menores espessuras dessas camadas, ou a uma maior vida de fadiga.

Os materiais utilizados na reciclagem apresentam uma grande variabilidade que ocorre pelo próprio processo de deterioração mecânica e química, bem como pelas diferentes origens desse material. Dessa forma, quando se utilizam agregados reciclados para misturas asfálticas, ou cimentadas, esse material deve passar por uma extensa caracterização (ARRA, 2001). 
Os materiais reciclados objetos desse estudo são misturas de solo e brita, provenientes da base do pavimento da Rodovia Fernão Dias, do km $451+500$ ao $\mathrm{km} 642+250$, acrescida de água e cimento, caracterizando, dessa forma, uma mistura do tipo solo-brita-cimento, que foram utilizados para compor a sub-base reciclada cimentada do pavimento restaurado.

Foi executado um trecho experimental com três segmentos distintos, variando-se a espessura de camada cimentada com o objetivo de se verificar a influência da espessura no comportamento estrutural do pavimento, além de verificar a eficiência da compactação nas diferentes espessuras.

\subsection{OBJETIVO}

Este trabalho tem por objetivo avaliar o comportamento da camada de base (solobrita) de pavimento submetido ao processo de reciclagem profunda através da adição de cimento. O estudo foi conduzido por meio de estudos laboratoriais do material empregado no processo de reciclagem e da avaliação de trecho experimental.

Dentro da matriz de ensaios de laboratório, tem-se como objetivos específicos:

- A obtenção de valores de resistência à tração, resistência à compressão, módulo de resiliência e módulo de elasticidade das misturas testadas,

- Avaliação de diferentes métodos de ensaio pertinentes ao material de estudo,

- Verificação da influência do tipo de material fresado na resposta das misturas recicladas com cimento,

- Análise do efeito do teor de cimento nas propriedades mecânicas das misturas, 
- Avaliação da energia de compactação (energia intermediária versus energia modificada), e

- Avaliação do tempo de cura na resistência à tração desse material reciclado cimentado.

Da construção do trecho experimental com camada de sub-base de material reciclado com cimento, objetiva-se:

- Verificar a eficiência de compactação de camadas recicladas com diferentes espessuras; e

- Avaliar o comportamento mecânico de misturas recicladas com cimento e a influência do tráfego nessas características.

\subsection{ORGANIZAÇÃO DA DISSERTAÇÃO}

O presente documento encontra-se dividido em seis capítulos, conforme descritos abaixo.

Capítulo 1 - Introdução

Apresenta os aspectos gerais da pesquisa, como essa se insere no contexto atual da pavimentação e seus objetivos.

Capítulo 2 - Revisão Bibliográfica

Apresenta uma revisão bibliográfica sobre o tema, abordando um histórico de aplicação da reciclagem de pavimentos e fundamenta conceitos da produção em laboratório e em campo de misturas cimentadas.

Capítulo 3 - Metodologia

Apresenta a sequência dos estudos e ensaios, bem como relaciona os métodos e materiais testados. 
Capítulo 4 - Estudo Laboratorial

São apresentados os ensaios de corpos de prova moldados em laboratório, bem como seus resultados, e características relevantes ao avanço da pesquisa.

Capítulo 5 - Trecho Experimental

Apresenta os aspectos relacionados ao trecho experimental desde sua construção até o monitoramento através de ensaios de campo e de laboratório.

Capítulo 6 - Conclusões e Recomendações 


\section{REVISÃO BIBLIOGRÁFICA}

\section{$2.1 \quad$ RECICLAGEM DE PAVIMENTOS}

A Europa foi o primeiro continente a utilizar a reciclagem na pavimentação nos modelos atuais, com a utilização de equipamentos apropriados e a preocupação com a ciência dos materiais. A reciclagem foi uma medida econômica e rápida para a reconstrução de rodovias após a II guerra mundial (BUCK, 1977). Nesse período o concreto proveniente da demolição de construções foi empregado como agregado na construção ou reconstrução de rodovias.

Nos Estados Unidos, materiais reciclados vêm sendo usados com sucesso na pavimentação nos últimos 30 anos (SCHIMMOLLER et al., 2000). Ainda de acordo com os mesmos autores, o governo federal e os estaduais lançaram pacotes incentivando tais iniciativas como a criação de legislação pertinente para a regulamentação do uso e da qualidade de tais materiais e a criação de centros de estudos em universidades para desenvolver pesquisas nesse âmbito.

Embora existam experiências no emprego de agregados reciclados (solo, concreto, pedras, argamassas, cerâmica vermelha e branca) na execução de pavimentação e este procedimento esteja em uso no Brasil desde o final da década de 80 , ainda não está disponível ao público documentação técnica abrangente e consistente (JOHN; AGOPYAN, 2000).

Com o aumento da população mundial, a diminuição de recursos naturais e a crescente preocupação em se adotar medidas sustentáveis, os governos cada vez mais incentivam e legislam a adoção da reciclagem como fonte de insumos nas diversas áreas da engenharia. Essas ações se dão em três frentes: (i) taxação da disposição de resíduos; (ii) taxação de insumos virgens; e (iii) legislação que obriga o uso da reciclagem nas obras.

A Suécia e a Inglaterra aplicam altas taxas na utilização de aterros e proíbem a disposição de materiais que podem ser reutilizados, dessa forma, a taxa de 
reciclagem na área de pavimentação nesses dois países chega próxima dos $100 \%$. $\mathrm{Na}$ Alemanha foram estabelecidas políticas de economia de utilização de materiais virgens estabelecendo a utilização da reciclagem para esse fim, fazendo da disposição dos resíduos o último recurso (SCHIMMOLLER et al., 2000).

No Brasil ainda não existe uma normatização federal que contemple os parâmetros para o emprego da reciclagem na pavimentação, no entanto iniciativas vêm sendo tomadas pelos munícipios. A prefeitura municipal de São Paulo (PMSP) exige um plano de manejo ambiental, que impede o descarte de resíduos de construção em aterros sanitários, terrenos públicos ou privados não credenciados para tal finalidade e a remoção para áreas externas ao município. Além disso, é exigida a utilização dos resíduos de pavimentação no próprio município.

\subsection{RESTAURAÇÃO DE PAVIMENTOS}

A restauração do pavimento se faz necessária quando existe o comprometimento estrutural do mesmo. As alternativas de restauração, ou reforço, compreendem aquelas que restabelecem ou incrementam sua capacidade estrutural por meio da incorporação de novas camadas à estrutura e/ou tratamento de camadas existentes (BERNUCCl et al., 2008).

Estudos indicam que quando as rodovias são mantidas a um nível de serviço elevado, em longo prazo elas custarão menos à sociedade. Um estudo do Banco Mundial aponta que cada $U \$ 1,00$ investido quando há queda de $40 \%$ na qualidade de uma rodovia, resulta em uma economia de $U \$ 3,00$ a $U \$ 4,00$ em relação ao gasto que seria necessário com a queda de $80 \%$ na qualidade da rodovia (ARRA, 2001), conforme ilustrado na Figura 1. 


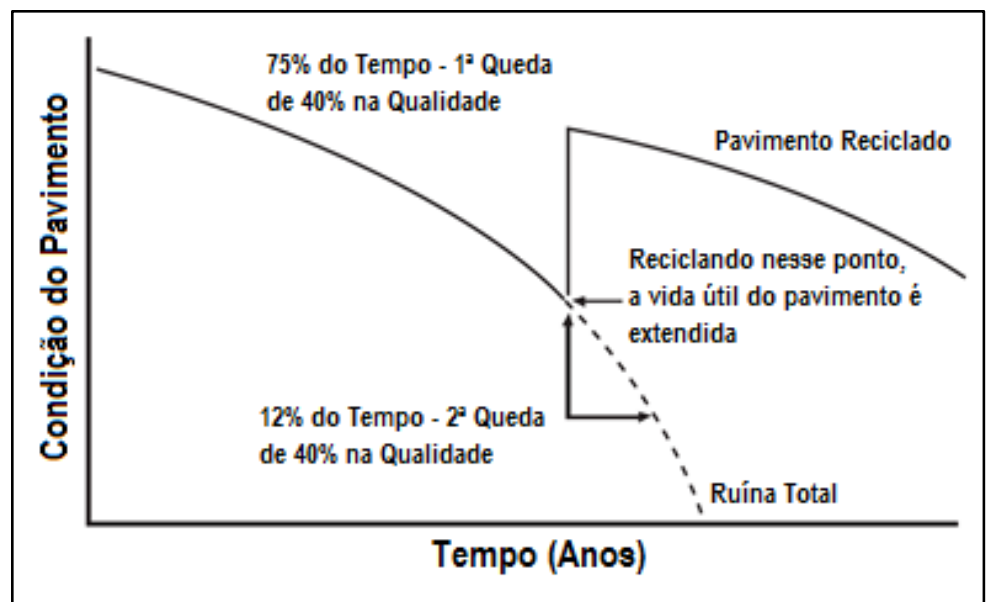

Figura 1 - Evolução da condição do pavimento (adaptado de ARRA, 2001)

Durante muito tempo, os órgãos responsáveis pela manutenção das rodovias usavam a adição de camadas sucessivas de concreto asfáltico sobre o pavimento danificado, a fim de se manter o nível de serviço e estender a vida útil dos pavimentos. A técnica de adição de camadas de recape gera problemas de conflito de alturas com as obras de arte, eliminação do desnível com o meio-fio e problemas de drenagem (TUCHUMANTEL, 1999).

Ao se comparar os custos de obras de restauração em pavimentação, verifica-se que esses são cerca de $60 \%$ superiores às obras que contemplam algum tipo de reciclagem (SALOMON; NEWCOMB, 2000). Quando os processos de restauração incluem a base do pavimento esses custos são ainda maiores. A Figura 2 apresenta a redução no consumo de materiais e energia com a utilização de reciclagem de base. 


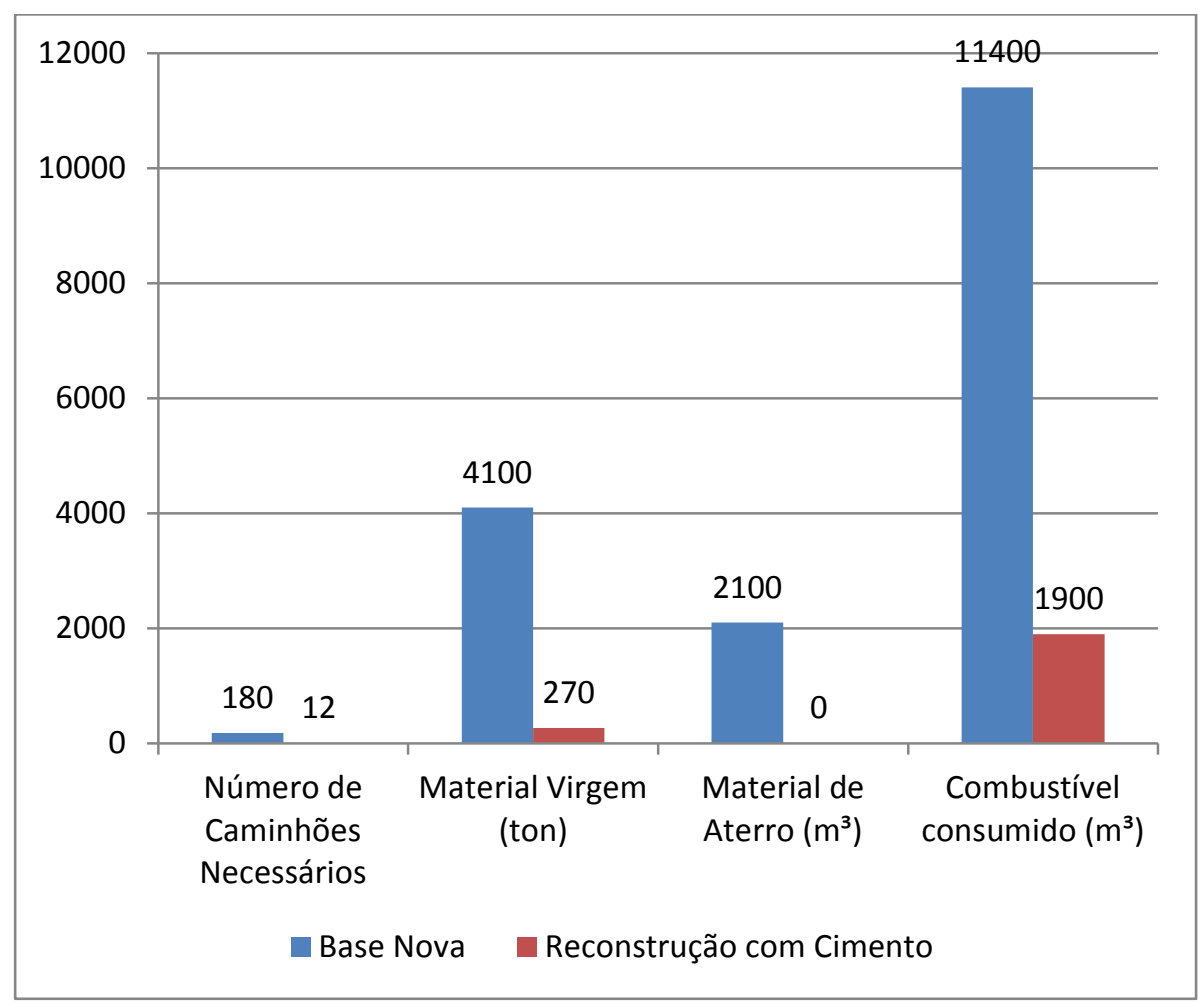

Figura 2 - Consumos de material (Adaptado de www.cement.org)

Além dos benefícios econômicos já estabelecidos, a reciclagem ajuda a resolver problemas associados à disposição dos materiais deteriorados e à manutenção do greide de vias existentes (KANDHAL; MALLICK, 1997b). Sabendo-se que o botafora associado à construção civil é um dos grandes responsáveis pelo resíduo sólido gerado, ele representa ônus ao meio ambiente e, portanto, sua redução além de ser contemplada na legislação é um benefício à sociedade.

\subsection{TÉCNICAS DE RECICLAGEM}

A Asphalt Recycling \& Reclaiming Association (ARRA) classifica os processos executivos de reciclagem em cinco categorias: reciclagem a frio in situ ou em usina; reciclagem a quente in situ ou em usina e a reciclagem profunda de pavimentos (Full Depth Reclaimation) (ARRA, 2001). Na literatura mais recente também é encontrada a reciclagem morna dos revestimentos asfálticos, que associa as técnicas de produção de misturas mornas à utilização de material fresado. 


\section{Reciclagem de revestimento a frio}

A reciclagem a frio é um processo que os materiais extraídos do revestimento asfáltico deteriorado são aplicados à frio em uma nova mistura, numa sequência que se inicia com a fresagem dos pavimentos deteriorados e termina com a disposição em pista da mistura reciclada (LIBERATORI et al., 2005).

As misturas a frio utilizam emulsão asfáltica, transportada e aplicada em temperatura ambiente, agregados provenientes da fresagem, água e aglomerante. Esta técnica traz além dos benefícios associados à utilização de agregados reciclados, o benefício ambiental de ser uma mistura a frio. Suas técnicas de execução não diferem das técnicas convencionais de misturas a frio em usina ou in situ.

\section{Reciclagem de revestimento a quente}

A reciclagem a quente assemelha-se em alto grau com a produção de misturas a quente convencionais, tanto que as usinas utilizadas são as mesmas (tipo gravimétrica ou volumétrica), com poucas adaptações, de acordo com o manual de reciclagem de pavimentos da FHWA (KANDHAL; MALLICK, 1997a). Os agregados fresados extraídos de pista são utilizados em campo ou transportados até a usina onde são aquecidos e adicionados à mistura que pode ou não conter agregados virgens. Contudo, Mallick et al. (2007) recomendam que o agregado fresado não seja exposto a altas temperaturas capazes de causar deterioração adicional ao material. A mistura é distribuída na pista e compactada também de modo similar ao concreto betuminoso usinado a quente.

\section{Reconstrução Profunda/ Reciclagem de base com cimento}

A reconstrução profunda de pavimentos é uma técnica onde a intervenção não ocorre apenas na camada de revestimento e sim nas camadas subjacentes, podendo atingir a base, sub-base e mesmo as camadas de reforço do subleito, com substituições do solo de fundação em alguns casos. Consiste da retirada e 
rebritagem de material deteriorado até a camada de interesse e posterior mistura e recompactação do material, representando uma nova camada de base ou sub-base. Por fim, executa-se nova camada de revestimento configurando-se a completa execução da reconstrução (ARRA, 2001).

\subsection{RECICLAGEM DE BASE COM CIMENTO}

A reciclagem profunda (Full Depth Reclamation - FDR) é uma técnica de reabilitação na qual o revestimento asfáltico e uma quantidade pré-determinada de material subjacente (base, sub-base e/ou subleito) são pulverizados e misturados uniformemente para fornecer um material de base melhorado e homogeneizado (ARRA, 2001).

Essa técnica tem se mostrado uma excelente opção para recuperação de pavimentos flexíveis degradados e com deficiência estrutural. Esse processo permite reconstruir parcialmente o pavimento velho, criando uma nova camada de base estabilizada de boa qualidade, homogênea e robusta, apta para receber novo revestimento (OLIVEIRA, 2003).

Os tipos de defeitos que podem ser tratados pela reciclagem profunda de acordo com a ARRA (ARRA, 2001) são:

- Trincas em bloco, longitudinais, transversais, de bordo, trincas por fadiga, por reflexão e pelo envelhecimento do ligante;

- Irregularidades no pavimento devido à empolamentos, afundamentos e depressões;

- Deformações permanentes na forma de trilhas de roda, corrugações e escorregamento;

- Perda de aderência entre as camadas do pavimento e desagregações; 
- Perda da integridade devido à desintegração da superfície, buracos e exsudação;

- Desnível excessivo do acostamento;

- $\quad$ Capacidade estrutural insuficiente.

O avanço dessa técnica de reciclagem se deve à chegada ao mercado de máquinas recicladoras autopropelidas, equipadas com motores de grande potência e com sistemas medidores para controlar a incorporação de água ou aditivos estabilizantes. As recicladoras atuais (Figura 3) evoluíram das fresadoras de asfalto e estabilizadoras de solo. São equipamentos de grande porte, altamente produtivos e podem cortar numa profundidade muito maior que suas predecessoras.

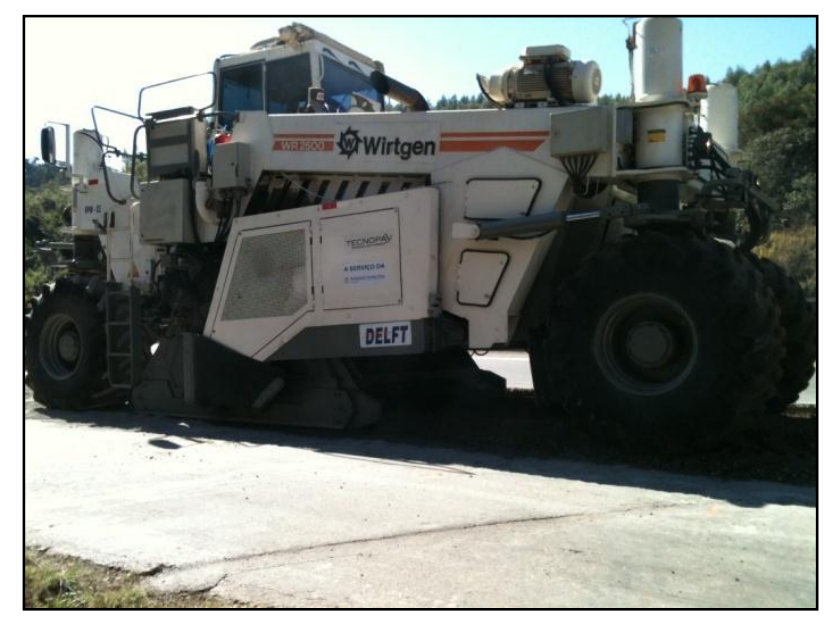

Figura 3 - Recicladora Wirtgen

A parte interna dessas máquinas consiste de um rolo misturador/fresador (Figura 4), equipado com um grande número de ferramentas de cortes especiais. $O$ rolo gira, fresando o material no pavimento existente. À medida que o processo de fresagem é efetuado, água ou agentes estabilizantes líquidos são introduzidos na quantidade exata na câmara misturadora (WIRTGEN,1998). 


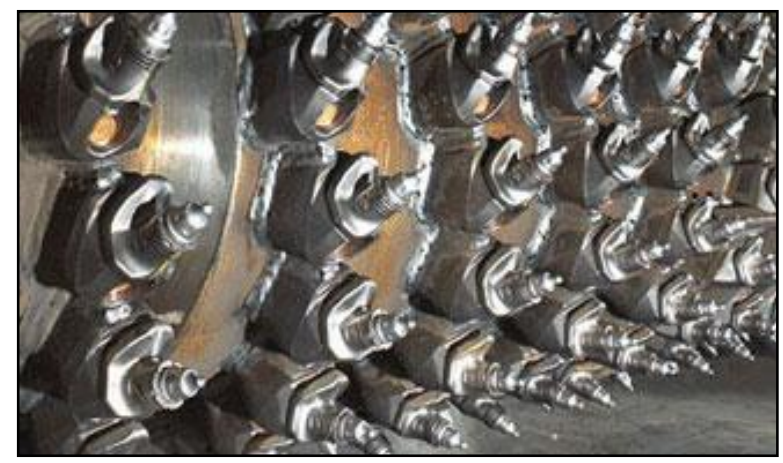

Figura 4 - Bits misturadores/fresadoras (adaptado de www.wirtgenbrasil.com.br)

A adição de cimento durante a reciclagem de base resulta em menores espessuras de revestimento betuminoso, ou de concreto. A camada de base será mais resistente e menos suscetível á água do que a base original implicando em menor necessidade de manutenção.

O processo detalhado da reciclagem de base com cimento é definido, conforme se segue, pela PCA (Portland Cement Association).

O processo de reciclagem da base com cimento tem início com o projeto estrutural do pavimento restaurado, onde são definidas as espessuras de cada camada. Essas definições são guiadas por investigações de campo e ensaios de laboratório para melhor avaliação dos materiais envolvidos.

A construção se inicia com a fresagem do revestimento existente e a escarificação do material a ser reciclado. Alguns equipamentos, no entanto, são capazes de fazer a escarificação antes de ter sido realizada a fresagem. O material escarifcado é então nivelado para respeitar a seção transversal definida, processo que pode implicar em remoção, ou adição, de material.

O cimento é adicionado de forma seca ou úmida (pasta de cimento). A água é aplicada para garantir umidade ótima de compactação. Por fim é feita a mistura e a compactação do material reciclado com cimento.

Para garantia da cura da camada cimentada, a PCA (PCA, 2012) estabelece que essa camada deve permanecer umedecida até que a camada seja capaz de resistir 
ao tráfego e à aplicação da camada de revestimento. No Brasil, o DER-SP (DER/SP, 2006b) indica a pintura com emulsão da camada cimentada finalizada para atingir o mesmo propósito.

O processo utilizado no trecho experimental, objeto desse estudo, apresenta uma pequena variação da técnica de reciclagem profunda convencional. A camada cimentada obtida nesse caso não conta com a adição dos agregados reciclados fresados do revestimento (RAP - Reclaimed Asphalt Pavement). Sendo assim, o processo de reciclagem restrito a essa base pode ser considerado um processo de estabilização com cimento.

Estabilização é o processo de homogeneização e mistura de materiais para melhorar certas propriedades do solo. O processo se dá pela homogeneização de solos para atingir a granulometria desejada ou a mistura de aditivos comercialmente disponíveis, que podem modificar a granulometria, textura, plasticidade, ou agir como um ligante para cimentação (USAF, 1994).

Quando cimento Portland, solo e água são misturados, uma ligação aglutinante entre as partículas do solo é formada. Essa mistura tende a ficar cada vez mais resistente com o passar do tempo. A estabilização com cimento funciona melhor quando a base e/ou subleito é granular, com o índice de plasticidade baixo (CATERPILLAR, 1996).

$\mathrm{Na}$ reciclagem de base do pavimento da Rodovia SC - 303, Trichês (2011) concluiu que a reciclagem do pavimento com cimento contemplando a incorporação do revestimento na camada de base propiciou uma redução significativa na deflexão do pavimento existente já no terceiro dia de cura da camada reciclada. Desta forma, a medida da deflexão logo nos primeiros dias de cura da camada reciclada, deve ser vista como uma medida quantitativa da qualidade do serviço.

Em estudo para a avaliação do desempenho de reconstruções profundas Mallick et al. (2002) observaram que o trecho experimental construído com reciclagem de base com a adição de 5\% de cimento não apresentou nenhum dano aparente após um ano de sua construção, ao contrário do que contou apenas com a incorporação de 
agregados fresados. Concluindo que, além dos benefícios de resistência, a adição de cimento reduz a suscetibilidade à água das bases.

\subsection{CARACTERÍSTICAS DE MISTURA CIMENTADA RECICLADA}

As propriedades dos agregados reciclados devem ser avaliadas de acordo com o projeto original e divididas em trechos homogêneos de acordo com o desempenho do pavimento e não apenas da área que apresenta problemas (ARRA, 2001).

A norma brasileira para a utilização de agregados reciclados em pavimentação apresenta valores limites para algumas propriedades que o material deve atender, tentando assegurar que a mistura apresente desempenho apropriado.

A especificação técnica EP-P00/035 do DER-SP especifica a distribuição granulométrica para utilização de agregados reciclados em bases cimentadas na pavimentação, podendo ser adicionados agregados virgens à mistura a fim de atender os limites definidos na norma (DER/SP, 2006b).

As características da mistura cimentada final são afetadas pelo tipo de agregado reciclado utilizado, pelo tipo e teor de cimento empregado, pela compactação e pela cura do material (ENAMORADO, 1990). Deve-se haver ainda um controle preciso na relação água/cimento, uma vez que o cimento Portland pode afetar sensivelmente as propriedades mecânicas das misturas (MEHTA; MONTEIRO, 2008).

\subsubsection{Agregados Reciclados}

Segundo a norma NBR 15114 (ABNT, 2004), agregados reciclados são os materiais granulares provenientes do beneficiamento de resíduos de construção da Classe $A$ que apresentam características técnicas para a aplicação em obras de edificação, de infraestrutura, de aterros, ou outras obras de engenharia. Sendo assim, são considerados agregados reciclados, resíduos: 
a) de construção, demolição, reformas e reparos de pavimentação e de outras obras de infraestrutura, inclusive solos provenientes de terraplanagem;

b) de construção, demolição, reformas e reparos de edificações: componentes cerâmicos (tijolos, blocos, telhas, placas de revestimento etc.), argamassa e concreto;

c) de processo de fabricação e/ou demolição de peças pré-moldadas em concreto (blocos, tubos, meios fios etc.) produzidas nos canteiros de obras.

Dentro dos resíduos utilizados como agregados reciclados provenientes da pavimentação estão: misturas asfálticas fresadas, denominadas RAP e materiais granulares, ou seja, brita, solo ou composições desses dois materiais.

O agregado reciclado material de estudo dessa dissertação, é uma mistura do tipo solo-brita, antiga base do pavimento da rodovia Fernão Dias. Segundo Pinto (2007), todos os solos se originam da decomposição física e/ou química de rochas que constituíam inicialmente a crosta terrestre.

Em relação às dimensões das partículas de solo, nota-se que são muito variáveis sendo classificadas em: pedregulho, areia, silte e argila. Os limites entre essas frações apresentam pequenas variações de acordo com a norma classificatória utilizada (FRANÇA, 2003). Assim, pode-se definir a mistura solo-brita como uma composição de solos.

As composições possuem características muito distintas, variáveis de acordo com o tipo de solo e sua distribuição granulométrica. Para a mistura reciclada poder ser considerada um solo-brita-cimento, ou um solo-cimento, o DER-SP (DER/SP, 2006a) estabelece limites para a faixa granulométrica, sendo prevista a incorporação de novos agregados para o caso de não conformidade.

As características do solo são dependentes da origem do mesmo. Segundo Macedo (2004), a crosta terrestre está dividida em camadas distintas, chamadas de horizontes (Figura 5) nas ciências dos solos. Cada horizonte possui propriedades 
originadas em sua formação e que resultam nas características principais dos solos, sendo elas: textura, cor, atividade biológica e tipo do agregado.

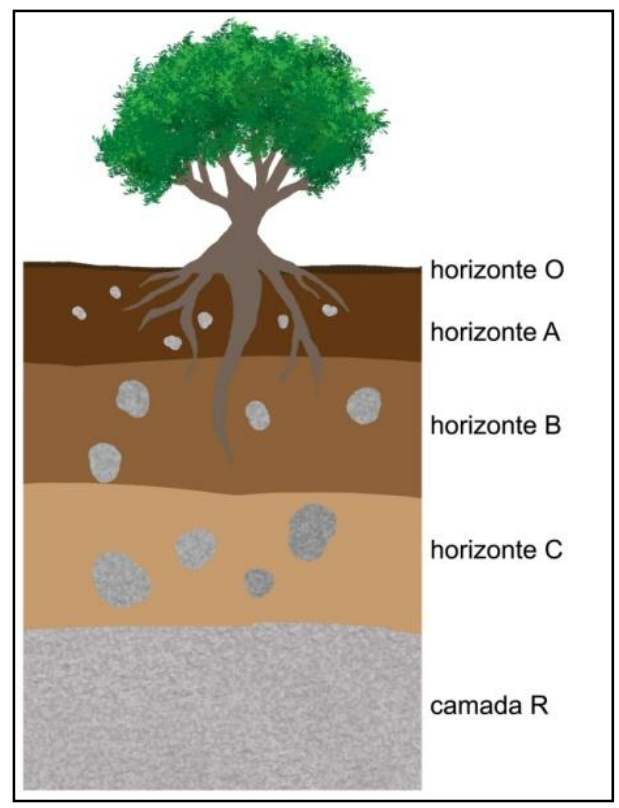

Figura 5 - Horizontes de formação dos solos (Fonte: Macedo, 2004)

Os solos utilizados em pavimentação são, normalmente, dos horizontes $B$ e $C$ (Tabela 1) e quando não atendem a algum requisito das especificações particulares para compor a camada do pavimento são submetidos à estabilização, em sua maioria por cimento Portland.

Tabela 1 - Nomenclatura dos horizontes de formação dos solos

\begin{tabular}{|c|l|}
\hline Horizonte & Características \\
\hline O & $\begin{array}{l}\text { Manta morta - Composto essencialmente por matéria orgânica, com a } \\
\text { porção superior rica em folhas e restos vegetais. Possui uma vasta } \\
\text { comunidade de microrganismos. }\end{array}$ \\
\hline A & $\begin{array}{l}\text { Nível rico em matéria mineral, com atividade biológica elevada e } \\
\text { presença de húmus, que Ihe confere uma tonalidade escura. }\end{array}$ \\
\hline B & $\begin{array}{l}\text { Camada formada em parte pela acumulação do material lixiviado das } \\
\text { camadas superiores. A acumulação de argilas permite aumentar a } \\
\text { capacidade de reter água no subsolo. }\end{array}$ \\
\hline C & $\begin{array}{l}\text { Composto por material parcialmente meteorizado, em que ainda é } \\
\text { possível identificar a rocha que Ihe deu origem. }\end{array}$ \\
\hline R & $\begin{array}{l}\text { Horizonte R ou Rocha-mãe - Este nível apresenta-se pouco } \\
\text { meteorizado, sendo o mais profundo. }\end{array}$ \\
\hline
\end{tabular}


De acordo com Wang (2002), a maioria dos solos pode ser estabilizado quimicamente, as exceções são os solos orgânicos, argilas muito plásticas e solos arenosos pouco reativos. Ainda de acordo com o autor, quanto mais fina a granulometria do solo, maior será a necessidade de cimento necessária em sua estabilização.

Os solos tropicais são aqueles formados em regiões de clima quente e úmido e que apresentam determinados comportamentos geotécnicos diferentes dos solos considerados tradicionais (CASTRO, 2003). Destacam-se duas grandes classes: os solos lateríticos e os solos saprolíticos.

Godoy (1997) caracteriza o solo laterítico como aquele que adquire elevadas resistências e capacidade de suporte ao ser devidamente compactado. Na presença de água, apresenta baixa permeabilidade e deformabilidade, e perde pouca capacidade de suporte.

Em relação aos solos saprolíticos, Castro (2003) diz que se originam da decomposição e/ou degradação in situ de uma rocha, mantendo a macroestrutura e constituição mineralógica desta rocha matriz.

Os solos tropicais são predominantes no Brasil, tanto em volume quanto em áreas de abrangência, e compreendem os solos saprolíticos pouco intemperizados e solos lateríticos altamente intemperizados (PESSOA, 2004).

\subsubsection{Teor de Cimento}

O cimento é um material inorgânico, finamente moído que misturado com água, forma uma pasta, que adensa e endurece em virtude das reações e processos de hidratação e que, depois de endurecido, matem a sua resistência e estabilidade mesmo quando imerso em água (VIEIRA, 2010).

Segundo Wang (2002), a maioria das aplicações utiliza o cimento Portland do Tipo I ou do Tipo II. O tipo de cimento varia de acordo com as propriedades desejadas e o 
tipo de solo. A quantidade de cimento pode variar de $4 \%$ a $16 \%$ do peso de solo seco. Geralmente, quando a proporção de solo argiloso aumenta, a quantidade de cimento necessária também aumentará.

A seleção da quantidade de aglomerante hidráulico a ser utilizada em uma camada de base deve levar em consideração os carregamentos impostos pelo tráfego e a solicitação pelo clima, além de proporcionar durabilidade para que suas propriedades não sejam severamente afetadas durante a vida de serviço (GUTHRIE et al., 2002).

No Brasil, a porcentagem em massa de cimento a ser incorporada à mistura reciclada é fixada de modo a atender a resistência à compressão simples e à tração no ensaio de compressão diametral, ambas aos 7, e 28 dias de cura, fixadas no projeto da estrutura do pavimento (DER-SP ET-DE-P00/035).

O método ABNT de dosagem sugerem valores mínimos de teor de cimento de acordo com a classificação HBR (ASTM D 3282) do solo contido nas misturas. Amostras compactadas no teor ótimo de umidade de compactação são ensaiadas à Resistência à Compressão Simples aos 7 dias de cura, para a determinação de sua resistência característica.

Ceratti e Casanova (1988) estudaram um método de dosagem para solo-cimento denominado "físico-químico". Esse método considera a interação elétrica entre as partículas de argila e as de cimento e consiste em se observar a variação da altura de expansão da mistura solo-cimento em excesso de água para os diversos teores de cimento candidatos. O teor selecionado, que levará à Resistência à Compressão pretendida é o que apresentar maior expansão. Esse método apresentou boa correlação com o ABNT já citado.

É sabido que quanto maior o consumo de cimento na mistura, maiores serão os valores de resistência obtidos, porém quanto maior o teor de cimento maior são as chances da ocorrência de fissuras ou trincas de retração na mistura (BALBO, 2007), dessa forma a dosagem da mistura é feita de modo que se atendam parâmetros de resistência de projeto com a menor quantidade possível de cimento. 
Em estudo de base estabilizada com cimento e agregado calcário, Guthrie et al. (2002) encontrou teor ótimo de cimento de $3 \%$ em massa, valor com o qual os corpos de prova atingiram valores satisfatórios de resistência, durabilidade e suscetibilidade à água. Miller (2009) determinou que $4 \%$ em massa de cimento levavam a resistência à compressão não confinada após 7 dias de cura a valores satisfatórios para quatro diferentes tipos de agregado, todos provenientes de fresagem de revestimento asfáltico ou base granular de diferentes localidades. Nesse mesmo estudo, verificou-se que fresados de revestimento asfáltico de mistura descontínua necessitam um percentual de cimento entre 6 e $8 \%$ em massa, devido à descontinuidade do esqueleto sólido original, aumentando a quantidade de cimento necessária.

A Tabela 2 relaciona resultados obtidos para alguns estudos que contemplaram misturas solo-cimento e/ou misturas solo-brita-cimento. Verificam-se as variações de propriedades mecânicas obtidas e suas variações de acordo com as dosagens.

Tabela 2 - Resultados de estudos contemplando misturas cimentadas

\begin{tabular}{|c|c|c|c|c|}
\hline Material & Solo Cimento & $\begin{array}{c}\text { Solo Brita } \\
\text { Cimento }\end{array}$ & $\begin{array}{c}\text { Solo Cimento } \\
\text { (Não Laterítico) }\end{array}$ & $\begin{array}{c}\text { Solo Cimento } \\
\text { (Laterítico) }\end{array}$ \\
\hline Referência & (BALBO, 2002) & (TOMEI, 2006) & (BECHARA, 2010) & (BECHARA, 2010) \\
\hline $\begin{array}{c}\text { Consumo de } \\
\text { Cimento (\% em } \\
\text { massa) }\end{array}$ & $8,6-9,9$ & $3-5$ & 6 & 6 \\
\hline $\begin{array}{c}\text { Resistência à } \\
\text { Tração (MPa) }\end{array}$ & 0,7 & $0,42-0,60$ & 0,73 & 0,64 \\
\hline $\begin{array}{c}\text { Resistência à } \\
\text { Compressão (MPa) }\end{array}$ & $7,2-7,8$ & $1,56-3,09 \mathrm{MPa}$ & 5,58 & 5,19 \\
\hline $\begin{array}{c}\text { Módulo de } \\
\text { Elasticidade ou } \\
\text { Resiliência (MPa) }\end{array}$ & $3700-7600$ & $3000-4000$ & 8312 & 5902 \\
\hline
\end{tabular}




\subsubsection{Compactação}

A compactação é a estabilização mecânica dos materiais que permite alcançar e conservar a maior resistência de qualquer estrutura de terra sem a utilização de qualquer aditivo (KÉZDI, 1988 apud FIDELIS, 2011).

Gregório (2010) afirma que na estabilização mecânica as propriedades do material são alteradas, é estabelecida uma nova condição de densificação máxima, relacionada a uma energia de compactação e a uma umidade ótima.

O teor ótimo de umidade é determinado em ensaio de compactação, realizado em cilindro padrão tipo Proctor, de modo que ocorra a maior densificação. O processo de compactação para misturas de solo-brita-cimento é o mesmo que para solos. Conforme se adiciona água à mistura aumenta-se a lubrificação entre partículas permitindo que essas se movam com mais facilidade diminuindo o volume de vazios com a compactação (PINTO, 2007).

A mistura atinge uma umidade ótima de compactação que confere a ela uma densidade máxima seca para a energia de compactação aplicada. A partir desse ponto, ao se adicionar água na mistura ela passa a dificultar a compactação por se posicionar em meio aos grãos e ser um fluído incompressível (PINTO, 2007).

A especificação técnica do DER-SP (DER, 2006) para execução de camadas de bases cimentadas define que deve ser utilizada a energia intermediária de compactação. As normas internacionais não contemplam tal energia, prevendo apenas a energia normal e a modificada.

Estudo realizado por Balbo (1993) demonstrou que britas graduadas tratadas com cimento (BGTC) apresentam valor máximo de resistência mecânica cerca de 30\% superiores quando dosadas a aproximadamente $1 \%$ abaixo da umidade ótima de compactação.

As características de resistência de misturas que contém cimento dependem basicamente da relação água/cimento contida na mistura. Quanto maior a 
quantidade de água contida na mistura maior será seu volume de vazios após a hidratação completa do cimento. Por sua vez, quanto maior o volume de vazios da mistura menor será sua resistência. Dessa forma, para o aumento da resistência buscam-se menores relações água/cimento (MEHTA; MONTEIRO, 2008).

Contudo, a redução da umidade na mistura afeta seu grau de compactação, resultando em densidades máximas menores da mistura compactada (PINTO, 2007). A fim de se compensar os efeitos negativos na compactação, causados por teor de umidade inferior, Balbo (1983) sugere adotar a energia modificada de compactação.

Por fim, é importante ressaltar que independentemente do material utilizado na camada do pavimento e da adição ou não de cimento, há a necessidade de se definir o grau de compactação mínimo a ser atingido em campo (FIDELIS, 2011).

\subsubsection{Tempo de cura}

A avaliação da evolução nas propriedades mecânicas de misturas estabilizadas com cimento Portland se faz necessária justamente pelas características de hidratação desse aglomerante, que faz com suas características químicas e físicas se modifiquem, passando do estado de pasta plástica à sólido.

O processo de hidratação do cimento possui três fases principais (MEHTA; MONTEIRO, 2008), conforme ilustrado na Figura 6:

(i) Na primeira, a pasta plástica de cimento se torna não trabalhável e é denominada início de pega. Este ponto marca o fim do período onde é possível fazer a mistura e compactação da camada;

(ii) Na segunda etapa, ocorre o fim da pega, onde é marcado o fim do processo de solidificação da mistura, contudo sua resistência ainda é considerada muito baixa. 
(iii) Por fim, acontece o endurecimento da mistura, processo no qual há o ganho de resistência provocado pela hidratação do cimento.

\begin{tabular}{|l|c|c|c|}
\hline \multicolumn{4}{|c|}{ Idade da hidratação } \\
\hline$<10 \mathrm{~min}$ & $\mathbf{1 0 - 4 5} \mathrm{min}$ & $\mathbf{1 - 2 \text { horas }}$ & $\mathbf{2 - 4}$ horas \\
\hline trabalhável & trabalhável & $\begin{array}{c}\text { menos } \\
\text { trabalhável }\end{array}$ & pega normal \\
& & \\
\end{tabular}

Figura 6 - Processo de hidratação do cimento (adaptado de Mehta e Monteiro, 2008)

A evolução nas propriedades de misturas com cimento e as reações químicas que as provocam são dependentes do tipo de materiais envolvidos, justificando assim a necessidade de uma avaliação do período de cura em misturas recicladas com incorporação de cimento Portland. Em termos de aplicação para pavimentação rodoviária, a determinação da evolução das propriedades mecânicas de uma mistura cimentada define o tempo para abertura ao tráfego, que se da quando a camada atingir resistência compatível aos níveis de solicitação locais.

O tempo para incremento de resistência mostra-se dependente do teor de cimento utilizado; quanto maior a quantidade de cimento empregado maior será o tempo necessário para a mistura chegar à constância de resistência, sendo os valores observados para a estabilização de 7 e 14 dias de cura para 3,5\% e 7\% de cimento, respectivamente (SPECHT, 2002).

A abertura ao tráfego se dá quando a base atinge resistência compatível aos níveis de solicitação locais. Para tanto, deve-se realizar a pintura de ligação e o salgamento para criação de uma camada de proteção mecânica da base (DER-SP ET-DE-P00/035). Apesar de a recomendação ser de 7 dias antes da execução da próxima camada, na prática adotam-se muitas vezes períodos de espera inferior, devido a limitações operacionais, especialmente em rodovias de tráfego intenso.

Estudos laboratoriais visando maior rapidez na execução de bases recicladas tratadas com cimento analisaram características mecânicas nas primeiras idades das misturas e determinaram quais períodos de cura menores são suficientes 
(MERIGHI, 2005). Merighi (2005) determinou que uma camada de base reciclada com adição de $3 \%$ e $5 \%$ de cimento é capaz de suportar um eixo padrão (80 kN) após 24 horas do início da mistura através de ensaios de resistência à tração e resistência à compressão. Miller (2009) verificou que após 2 dias de cura uma base reciclada cimentada possui módulo elástico entre 200 e 700 \% superior em relação ao mesmo material sem adição de cimento.

\subsection{A MISTURA CIMENTADA NA ESTRUTURA DO PAVIMENTO}

A estabilização de materiais de pavimentação com ligantes hidráulicos vem sendo utilizada desde a época do império romano. Conscientes da necessidade de pavimentos mais resistentes e duráveis os romanos utilizavam a estabilização dos solos pela adição de pozolanas e cal (BOLIS, 1949 apud BALBO, 1993). Dessa forma as vias podiam ser utilizadas por tráfego mais intenso e possuíam menor necessidade de manutenção.

A utilização do cimento Portland na estabilização de bases que contém solo tem sido amplamente estudada, com verificações de melhora das propriedades mecânicas de resistência à tração e à compressão da mistura, além de elevar o módulo elástico da camada e garantir menor deformabilidade à mistura. Experimentos mostram que a capacidade de distribuição de esforços de $10 \mathrm{~cm}$ de camada cimentada pode equivaler a $25 \mathrm{~cm}$ de brita graduada simples (BGS), o que torna tais camadas mais eficientes (BALBO, 1993).

Verificou-se que a presença de uma camada cimentada tem o efeito de elevar o módulo elástico reduzindo as deformações de tração sob a camada asfáltica. Esse efeito permite a redução na espessura do revestimento betuminoso em relação à requerida em um pavimento flexível convencional equivalente (SUZUKI, 1992).

As estruturas do pavimento são usualmente classificadas em flexíveis ou rígidas, sendo tais designações insuficientes e restritivas, visto as variações mais recentes utilizadas no sistema de camadas dos pavimentos (BALBO, 2007). O princípio básico sugere que pavimentos de concreto têm estruturas rígidas e pavimentos 
asfálticos possuem estrutura flexível. São consideradas as seguintes definições consagradas na literatura internacional (BALBO, 2007):

Pavimento flexível - composto apenas por camadas asfálticas e/ou granulares, são caracterizados por serem deformáveis e apresentarem comportamento resiliente, de modo que as tensões atuam de forma mais concentrada nas proximidades do ponto de aplicação de carga (Figura 7).

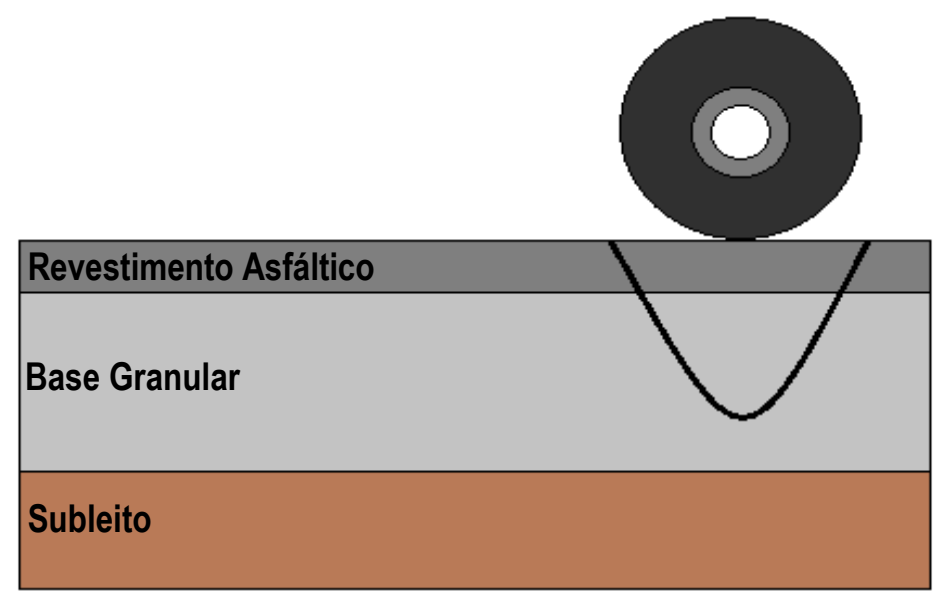

Figura 7 - Pavimento flexível (Adaptado de Balbo, 2007)

Pavimento rígido - possui apenas camadas em concreto de cimento Portland e/ou camadas cimentadas, sendo que a estrutura responde com a dispersão das tensões aplicadas num campo mais amplo. As camadas apresentam elevada rigidez e fragilidade (Figura 8).

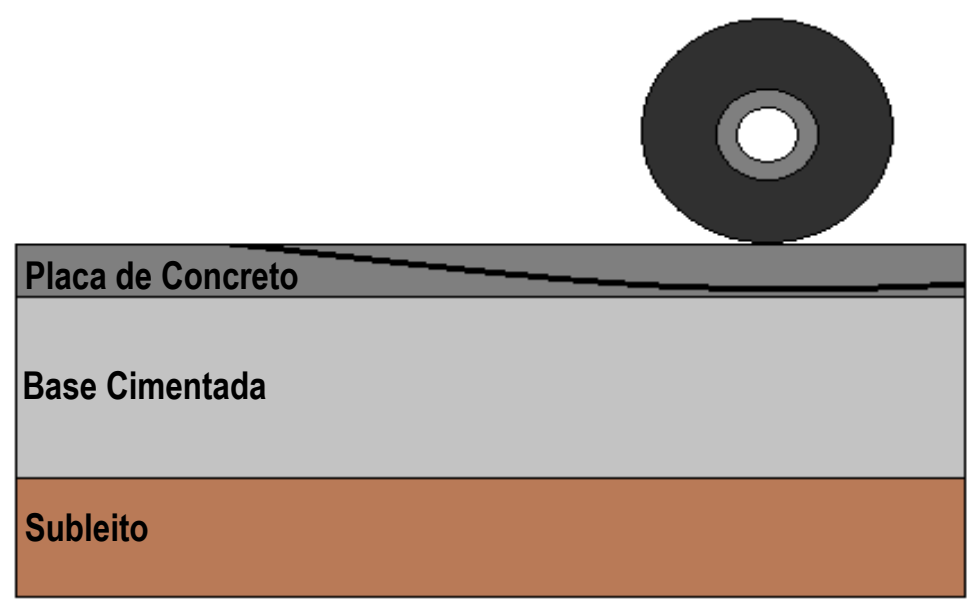

Figura 8 - Pavimento rígido (Adaptado de Balbo, 2007) 
Pavimento semirrígido - tem a base constituída por material estabilizado com ligante hidráulico, e revestimento flexível trabalhando sobre tensão de compressão devido à alta rigidez da camada cimentada (Figura 9).

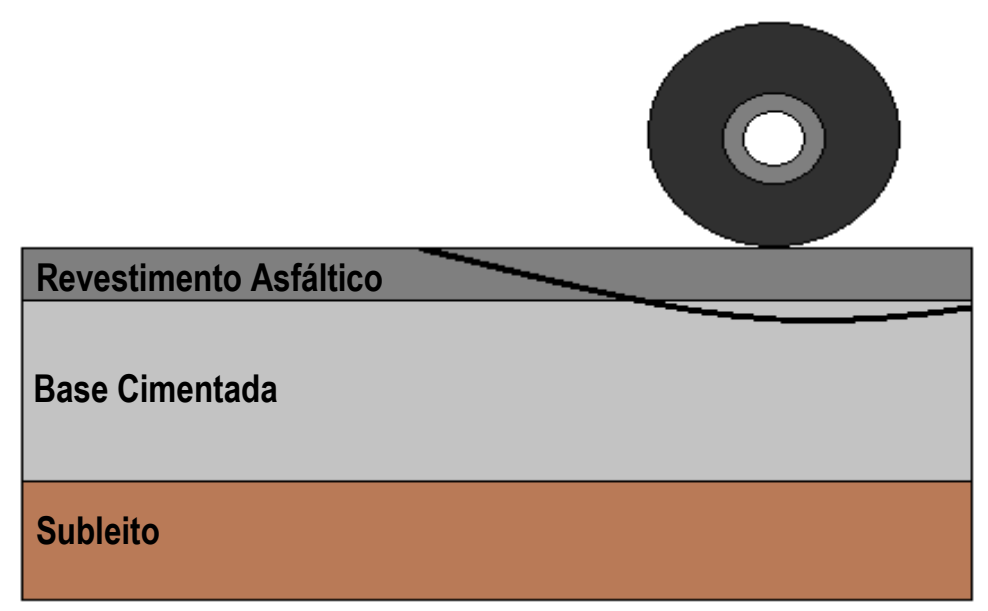

Figura 9 - Pavimento semirrígido (Adaptado de Balbo, 2007)

Ao se reciclar a base granular de um pavimento flexível, adicionando cimento a essa camada o pavimento passa a apresentar uma estrutura semirrígida com comportamento conforme o descrito acima.

Um dos principais problemas associados a este tipo de pavimento é a reflexão de trincas da camada cimentada para o revestimento asfáltico. $\mathrm{O}$ trincamento verificado no início da vida de serviço é atribuído ao processo de retração, inerente à cura do material. O trincamento por fadiga ao longo da vida de serviço também representa um importante processo que afeta a durabilidade da camada cimentada, causando a redução de rigidez em função do aumento do grau de fissuração.

Suzuki (1992) estudou estruturas de pavimentos semirrígidos com sub-base cimentada e uma camada granular fazendo às vezes de base, de modo a se reduzir o problema de reflexão de trincas. Esse estudo teve como conclusão que a presença da camada granular aumenta as tensões de tração no revestimento, quando comparado com o pavimento semirrígido tradicional. Contudo, essa inversão também proporciona redução de tensões atuantes na camada cimentada e deformação de compressão no topo do subleito. 


\subsection{DESEMPENHO DO PAVIMENTO SEMIRÍGIDO}

Foram observadas mudanças na forma que se projetam pavimentos, sendo que atualmente pode-se afirmar que a ruptura ocorre por diferentes motivos, sendo que as que estão associadas às repetições de carga são o fenômeno da fadiga, responsável pela fissuração de revestimentos betuminosos e de bases cimentadas e o acúmulo de deformações plásticas (permanentes) devido à ação das deformações cisalhantes que ocorrem em camadas granulares e no subleito (SEVERI et al., 1999).

Os pavimentos semirrígidos apresentam comportamento estrutural distinto dos pavimentos flexíveis convencionais. Sendo que o trincamento por fadiga ocorre na camada cimentada, decorrente de sua natureza frágil. Quando a camada cimentada atinge um elevado grau de fissuração passa a se comportar como uma base granular levando a camada asfáltica a sofrer tensões de tração e a propagação das trincas (BALBO, 2006).

A camada cimentada também pode sofrer degradação por perda de coesão, defeito que surge por subdimensionamento, má qualidade da mistura cimentada, compactação deficiente, camadas inferiores com baixa capacidade de suporte e por perturbação da hidratação da mistura, devido à abertura antecipada ao tráfego (SANTOS, 2009).

Tal como nos pavimentos rígidos, a camada de base tratada com cimento sofre retração, originando trincas transversais, que se propagam para as camadas betuminosas, levando ao seu trincamento.

Os defeitos provenientes da ruptura da camada cimentada manifestam-se com o aparecimento de trincas em forma pele de crocodilo, em malha estreita, eventualmente acompanhada de subida de finos.

Os métodos de projeto existentes foram, via de regra, concebidos de duas maneiras distintas: com base no desempenho ao longo do tempo, obtido através de 
experiências de campo (modelos empíricos) ou a partir de teoria elástica considerada adequada para a interpretação do fenômeno (modelos semi-teóricos). Alguns métodos apresentam ainda uma associação de modelos empíricos com modelos teóricos (semi-empíricos) (SEVERI et al., 1999).

No dimensionamento destes pavimentos utilizam-se leis de fadiga diferentes dos pavimentos flexíveis, pois devido à sua constituição há uma maior distribuição das tensões para as camadas inferiores. O critério de ruína condicionante é a tensão de tração máxima na base da camada rígida, constituída (SANTOS, 2009).

Balbo (1993) propôs um modelo de quatro camadas para cálculo de tensões de tração na flexão na fibra inferior da camada cimentada (BGTC ou CCR). Contudo esse modelo apresenta faixas restritas de propriedades dos materiais empregados, limitando sua utilização devido a grande variabilidade encontrada em misturas contendo solo.

Existem maneiras de evitar ou retardar a propagação das trincas decorrentes de fadiga, desagregação ou retração da camada cimentada paras as camadas subjacentes. São elas:

- Aplicação de penetração betuminosa;

- Colocação de uma camada em agregado britado de granulometria aberta entre as camadas betuminosas e a base tratada com cimento (pavimento semirrígido invertido);

- Interposição de uma argamassa betuminosa constituída por um agregado de dimensão máxima de $5 \mathrm{~mm}$ e por um betume modificado por polímero;

- Aplicação de um geotêxtil após a aplicação de uma pintura com emulsão betuminosa catiônica rápida;

- Indução ordenada de fissuras na camada de base, com um espaçamento de 5 a 15 metros. 


\section{METODOLOGIA}

A pesquisa foi organizada e conduzida em duas frentes distintas de trabalhos, separando resultados referentes ao experimento de campo, dos resultados referentes ao estudo laboratorial, tendo o estudo de laboratório o objetivo de guiar e justificar resultados obtidos em campo.

\subsection{ESTUDO LABORATORIAL}

Os estudos laboratoriais foram conduzidos com dois materiais distintos, ambos extraídos de campo (material de base da rodovia Fernão Dias). O primeiro deles coletado no próprio trecho experimental durante a construção (Material 1) e o segundo coletado em local distinto, próximo ao trecho experimental (Material 2) da mesma rodovia, próximo ao trecho experimental. Os materiais distintos refletem a variabilidade comum de uma obra rodoviária, cujas jazidas de materiais naturais sofrem variação, mantendo a homogeneidade do ponto de vista de engenharia, mas muitas vezes não mantendo o aspecto mineralógico.

Esses dois materiais foram divididos em cinco grupos de corpos de prova com dosagens distintas a fim de se avaliar o efeito das variações nas misturas abaixo descritas. A matriz de ensaios resultante é apresentada na Tabela 3.

Com base nesses grupos foram avaliadas as diferenças em resultados mecânicos variando-se as características de materiais, dosagem (teor de cimento), energia de compactação e metodologia de ensaio. As características avaliadas são apresentadas a seguir:

1. Avaliação da metodologia de ensaio: $O$ Material 2 foi avaliado em termos de módulo de resiliência, resistência à tração, resistência à compressão e módulo de elasticidade, variando-se o método de ensaio entre ensaios de ruptura para materiais granulares e concreto/argamassas. 
2. Comparação entre materiais: Os Materiais 1 e 2 estudados, de características distintas apesar de terem sido extraídos da base da mesma rodovia, foram avaliados em termos de resistência à tração e resistência à compressão, mantidas todas as outras características constantes.

3. Comparação entre teores de cimento: $O$ Material 2 foi avaliado em termos de módulo de resiliência, resistência à tração e resistência à compressão, variandose o teor de cimento na mistura e mantidas todas as outras características constantes.

4. Comparação entre energias de compactação: O Material 2 foi avaliado em termos de resistência à tração e resistência à compressão, variando-se a energia de compactação da mistura e mantidas todas as outras características constantes.

5. Avaliação do tempo de cura: O Material 2 teve sua cura avaliada em termos de resistência à tração desde o primeiro dia após a moldagem até o $28^{\circ}$ dia. 
Tabela 3 - Matriz de ensaios

\begin{tabular}{|c|c|c|c|c|c|c|c|c|}
\hline & \multirow[b]{2}{*}{ Tempo de Cura } & \multicolumn{3}{|c|}{ Energia Intermediária } & \multicolumn{3}{|c|}{ Energia Modificada } \\
\hline & & & 3 dias & 7 dias & 28 dias & 3 dias & 7 dias & 28 dias \\
\hline \multirow{3}{*}{ 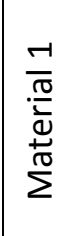 } & \multirow{3}{*}{$5 \%$ de Cimento } & Resistência à Tração & $x$ & $x$ & $x$ & & & \\
\hline & & $\begin{array}{l}\text { Resistência à } \\
\text { Compressão }\end{array}$ & $x$ & $x$ & $x$ & & & \\
\hline & & Módulo de Resiliência & & & & & & \\
\hline \multirow{9}{*}{$\begin{array}{l}\frac{N}{\pi} \\
\frac{\pi}{\frac{\pi}{2}} \\
\frac{ \pm}{\pi} \\
\sum\end{array}$} & \multirow{3}{*}{$5 \%$ de Cimento } & Resistência à Tração & $x$ & $x$ & $x$ & $x$ & $x$ & $x$ \\
\hline & & $\begin{array}{l}\text { Resistência à } \\
\text { Compressão }\end{array}$ & $x$ & $\mathrm{x}$ & $x$ & $x$ & $x$ & $x$ \\
\hline & & Módulo de Resiliência & & & & $x$ & $x$ & $x$ \\
\hline & \multirow{3}{*}{$6 \%$ de Cimento } & Resistência à Tração & & & & $x$ & $x$ & $x$ \\
\hline & & $\begin{array}{l}\text { Resistência à } \\
\text { Compressão }\end{array}$ & & & & $x$ & $x$ & $x$ \\
\hline & & Módulo de Resiliência & & & & $x$ & $x$ & $x$ \\
\hline & \multirow{3}{*}{$7 \%$ de Cimento } & Resistência à Tração & & & & $x$ & $x$ & $x$ \\
\hline & & $\begin{array}{l}\text { Resistência à } \\
\text { Compressão }\end{array}$ & & & & $x$ & $x$ & $x$ \\
\hline & & $\begin{array}{c}\text { Módulo de } \\
\text { Resiliência/Elasticidade }\end{array}$ & & & & $x$ & $x$ & $x$ \\
\hline
\end{tabular}

\subsection{O ESTUDO DE CAMPO}

Os estudos de campo foram realizados por meio do monitoramento de bacias de deflexão do trecho experimental para o acompanhamento das características estruturais da camada de base reciclada com cimento em suas condições de campo, exposta ao tráfego e as intempéries.

Os levantamentos de bacia de deflexão foram realizados logo após a construção do trecho experimental e um ano após a abertura ao tráfego. O equipamento selecionado foi o Falling Weight Deflectometer (FWD) que apresenta a captura eletrônica dos dados da bacia de deflexões completa, permitindo maior precisão na avaliação do comportamento mecânico por meio dos resultados. 
Além disso, foram extraídos corpos de prova, após a cura completa do material em campo, 7 meses após a construção do trecho experimental, para a realização de ensaios laboratoriais de caracterização mecânica. Devido ao número reduzido de corpos de prova extraídos, optou-se pela realização de ensaios de módulo de resiliência, módulo de elasticidade e resistência à compressão nessas amostras.

A avaliação de dois procedimentos de ensaio para determinação do módulo das misturas pretende quantificar as diferenças entre o comportamento do material em distintos métodos de ensaio, uma vez que essa é uma mistura que apresenta características entre o comportamento de um solo e de um concreto. Além disso, os métodos de ensaio e de carregamento são bastante distintos para a determinação dessas duas grandezas. 


\section{ESTUDO LABORATORIAL}

Os materiais reciclados possuem características físicas e mecânicas bastante peculiares que necessitam ser conhecidas para que tais materiais possam ser utilizados em projetos. Nesse capítulo são apresentados os resultados da caracterização dos materiais de base extraídos de campo e de ensaios mecânicos em corpos de prova moldados em laboratório.

\subsection{CARACTERIZAÇÃO DOS MATERIAIS}

Foram extraídas duas amostras de base em solo-brita, de pontos distintos do pavimento deteriorado na rodovia Fernão Dias. Essas amostras diferem em termos de distribuição granulométrica e tipo de solo utilizado, de forma que os materiais foram ensaiados a fim de se quantificar e diferenciar tais características. A amostra denominada Material 1 é o mesmo material que compõe a base reciclada com cimento do trecho experimental abordado no capítulo a seguir. A amostra denominada Material 2 foi retirada de um local distinto, mas também da base na própria rodovia, próximo ao trecho experimental.

\subsubsection{Distribuição Granulométrica}

A distribuição granulométrica dos agregados é uma de suas principais características, já que influencia em propriedades como resistência, rigidez e coesão das misturas (BERNUCCl et al., 2007). As amostras para o ensaio de determinação de curva granulométrica foram obtidas por quarteamento, conforme preconiza o método de ensaio DNER-ME 083/98 e o ensaio realizado por peneiramento manual (Figura 10). Os resultados do ensaio de granulometria são apresentados na Figura 11. 

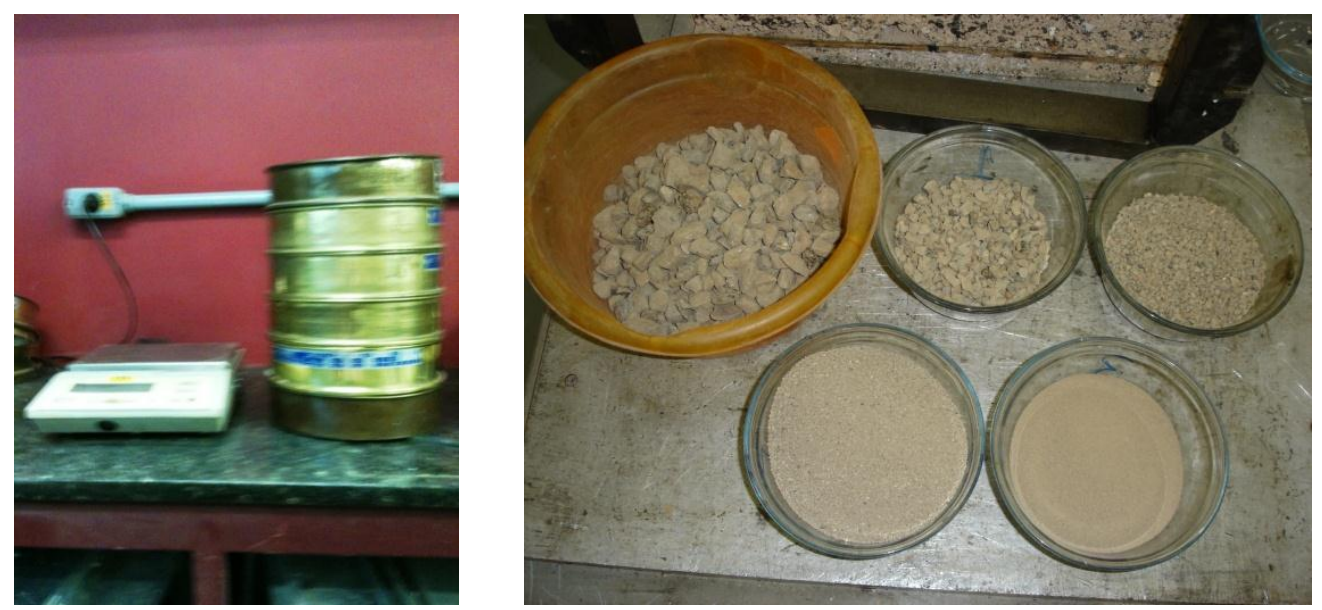

Figura 10 - Ensaio de granulometria

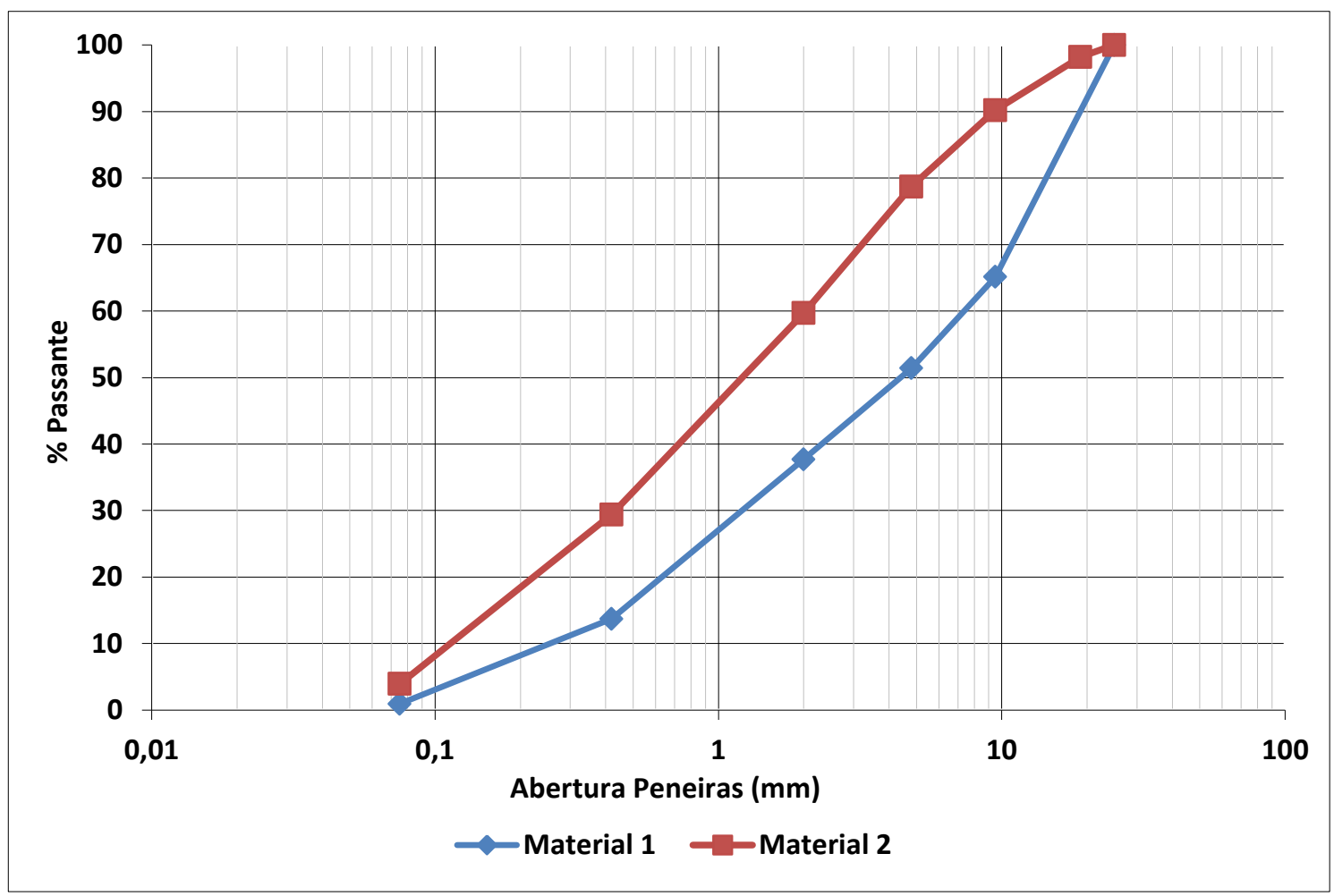

Figura 11 - Curva granulométrica dos materiais

A diferença na granulometria entre os materiais estudados é bastante evidente. $\mathrm{O}$ Material 1 apresenta uma maior quantidade de fração graúda, sendo a proporção Solo/Brita, limitada pela peneira de $2 \mathrm{~mm}$ de abertura, é de $40 \%$ de solo para $60 \%$ de brita, já o Material 2 apresenta predominância da fração fina, sendo a proporção Solo/Brita de $60 \% / 40 \%$. 
A distribuição granulométrica do Material 1 atende aos limites estabelecidos para bases em solo-brita-cimento definidos pelo DER/SP (DER/SP, 2006), como apresentado no gráfico da Figura 12. Dessa forma, espera-se que o comportamento mecânico da mistura com o Material 1 se assemelhe ao comportamento desse tipo de material.

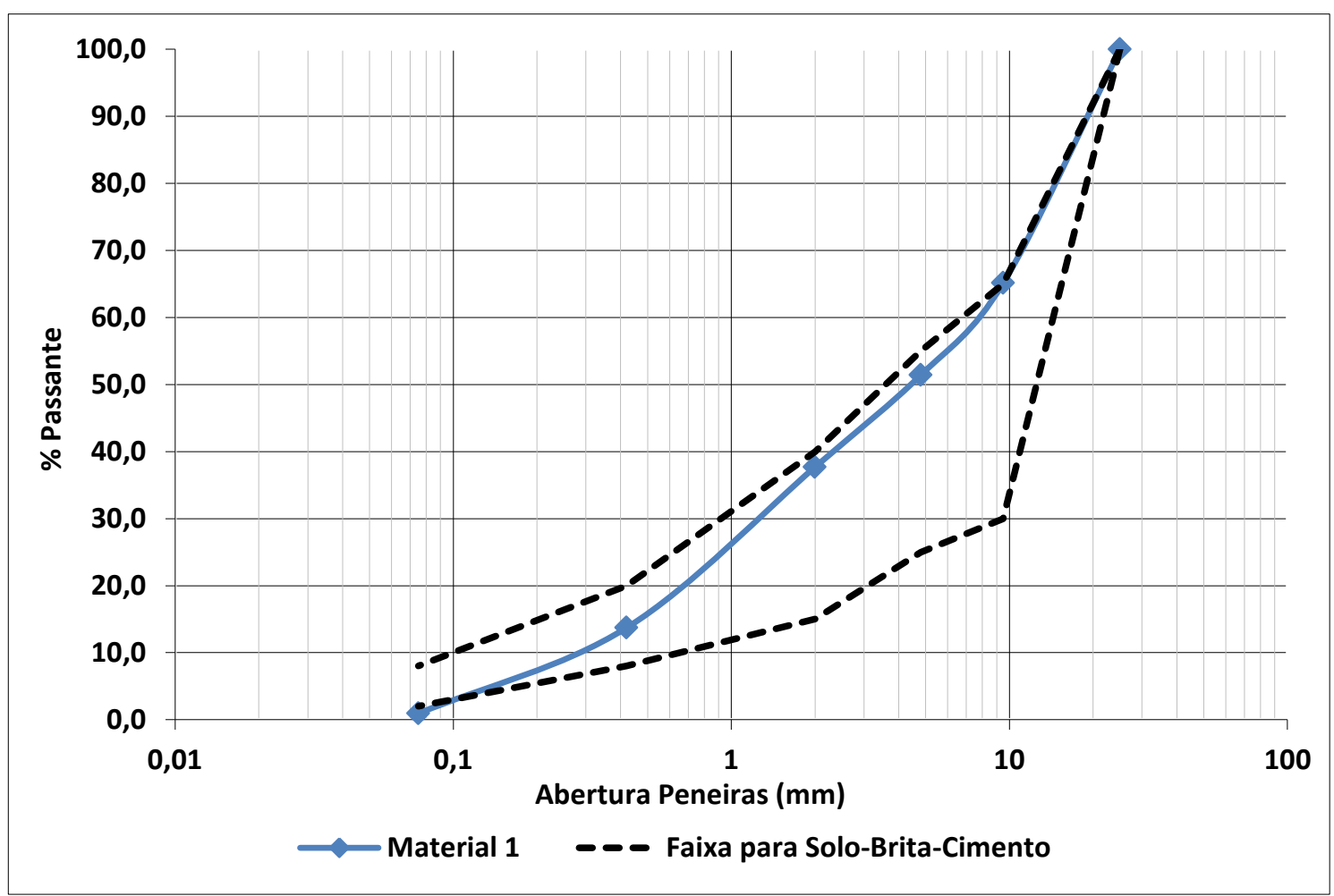

Figura 12 - Distribuição granulométrica para misturas solo-brita-cimento (DER/SP ET-DE-P00/007A)

A predominância da fração solo presente no Material 2 faz com que as misturas apresentem um comportamento mecânico mais semelhante ao de um solo-cimento, tendo a parcela de brita menor influência para esse segundo material. De fato, a distribuição granulométrica do Material 2 atende aos limites especificados para bases em solo-cimento definidos pelo DER/SP (DER/SP, 2006), como apresentado no gráfico da Figura 13. Devido a essas variações granulométricas e percentual da fração solo, espera-se que o Material 2 apresente consumo de cimento superior ao Material 1 para atingir mesmos níveis de resistência. 


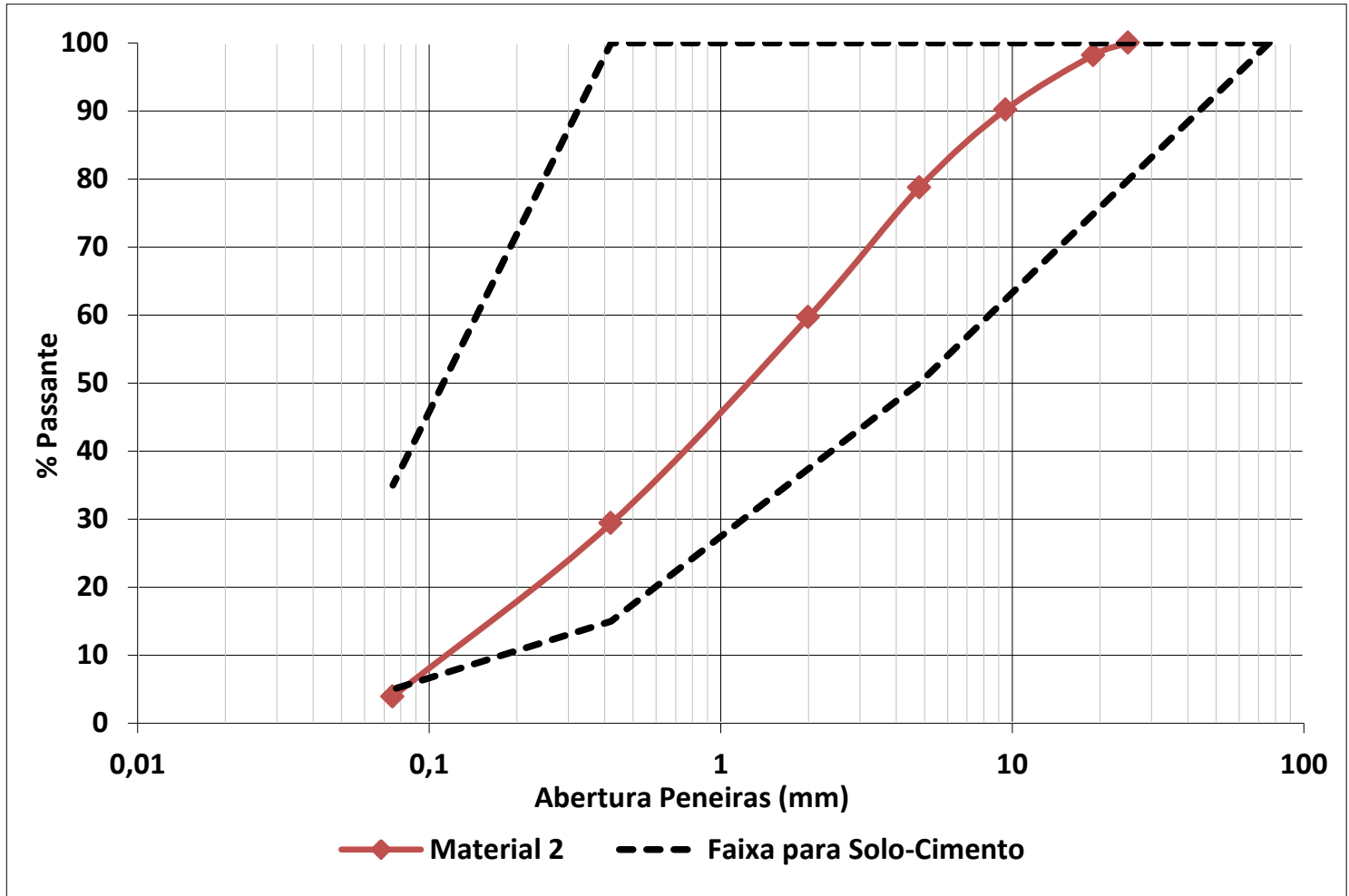

Figura 13 - Distribuição granulométrica para misturas solo-cimento (DER/SP ET-DE-P00/035A)

\subsubsection{Classificação da Fração Solo}

As propriedades mecânicas de misturas de solo-brita-cimento estão associadas não apenas à granulometria do material, mas também à hidratação do cimento. Esse processo está diretamente ligado ao tipo de solo presente na mistura, de forma que os solos contidos nas duas misturas foram classificados de acordo com o método das pastilhas, procedimento expedito de classificação da metodologia MCT (NOGAMI, 1994).

Para a classificação do solo contido nas misturas de solo-brita selecionou-se o material passante na peneira $n^{\circ} 40$, conforme estabelecido no procedimento para 0 ensaio do método das pastilhas. As pastilhas foram submetidas ao ensaio de contração (Figura 14) e penetração por agulha e altura padronizadas (Figura 15). 

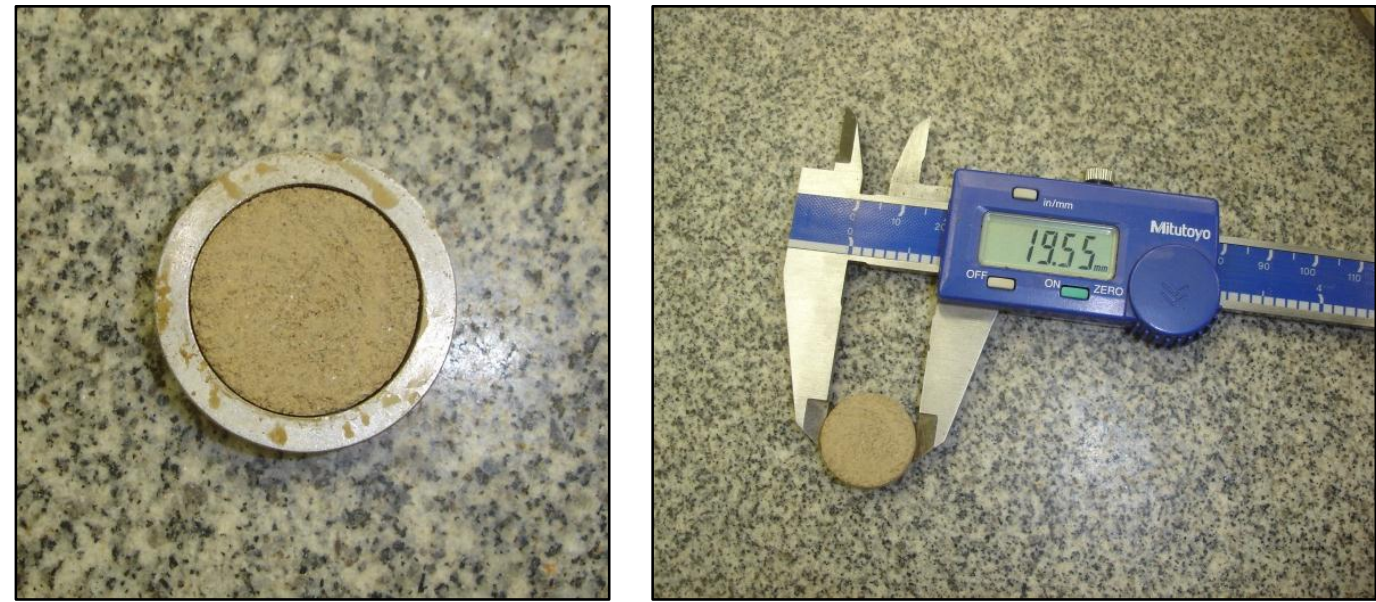

Figura 14 - Ensaio de contração (metodologia MCT)

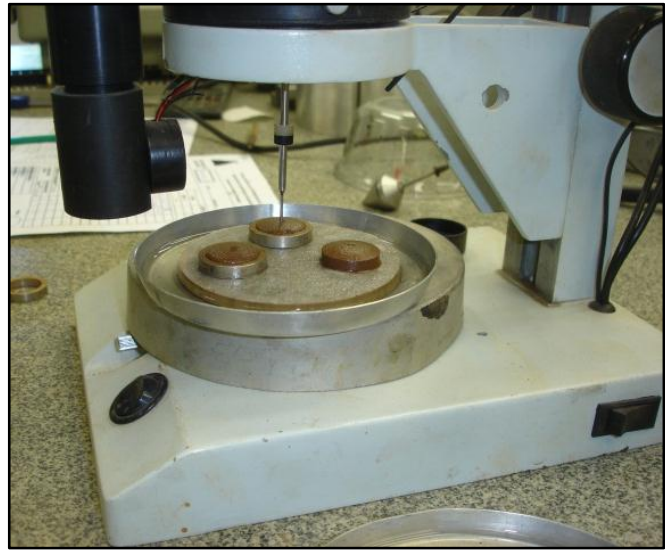

Figura 15 - Ensaio de penetração (metodologia MCT)

Os resultados apresentados na Tabela 4 estabelecem que as duas misturas de solobrita diferem também na classificação e comportamento dos solos que às compõem. O Material 1 apresenta solo de comportamento laterítico, enquanto o Material 2 apresenta solo de comportamento não laterítico.

Tabela 4 - Resultados da classificação do solo

\begin{tabular}{|c|c|c|c|}
\hline Solo & Contração $\mathbf{( m m})$ & Penetração $\mathbf{( m m})$ & Classificação \\
\hline Material 1 & 0,40 & 1,5 & LA-LA' \\
\hline Material 2 & 0,40 & 5,0 & NS'-NA' $^{\prime}$ \\
\hline
\end{tabular}

A diferença de comportamento do solo vai influenciar no comportamento mecânico final da mistura cimentada. Estudando características de misturas cimentadas, Parente et al. (2002) observaram que, em geral, solos lateríticos apresentaram maiores incrementos de resistência quando comparados aos não lateríticos. 
Contudo apenas essa classificação não é determinante para o comportamento das misturas do tipo solo-cimento ou solo-brita-cimento. Bechara et al. (2010) observaram que misturas de solo-cimento preparadas com solos não lateríticos apresentaram valores de resistência superiores às misturas com solos lateríticos, tendo os autores atribuído o melhor comportamento da mistura com solo não laterítico à sua maior compatibilidade química com o cimento.

Ao avaliar diversas misturas de solo-cimento, Ceratti (1991) não obteve um padrão de resultados de resistência à tração quando comparando solos de comportamento laterítico e não laterítico. Os pares de amostra com mesmo consumo do cimento variaram em termos de resistência à tração, independente da natureza laterítica, ou não, do solo. Dessa forma, é possível afirmar que a compatibilidade do solo com o cimento depende não apenas do comportamento obtido na classificação, mas também de propriedades químicas e mineralógicas do mesmo.

\subsection{PROJETO DAS MISTURAS}

A dosagem de misturas de solo-brita-cimento e solo-cimento é feita de modo que a mistura final atinja os valores de propriedades mecânicas estabelecidos no projeto estrutural do pavimento. Para tanto, fixa-se uma faixa granulométrica do material e uma energia de compactação, e variam-se os teores de cimento e, portanto, a umidade ótima de compactação para tais composições, até se obter as propriedades mecânicas desejadas.

Cinco misturas recicladas com cimento foram avaliadas neste trabalho, sendo variado o percentual de cimento, a energia de compactação e o material reciclado. Apenas quatro das cinco misturas tiveram suas umidades ótimas obtidas por meio da curva de compactação do material, segundo a especificação NBR 7183 (ABNT, 1986). Com o objetivo de minimizar o consumo de material, uma das umidades ótimas foi definida pela extrapolação dos resultados obtidos nas demais misturas, descritas a seguir. Os resultados são apresentados na Tabela 5. Essas variações respeitam a matriz de ensaios definida na metodologia de pesquisa dessa dissertação. 
Tabela 5 - Misturas avaliadas

\begin{tabular}{|c|c|c|c|}
\hline \multirow{2}{*}{ Material } & $\begin{array}{c}\text { Energia de } \\
\text { Compactação }\end{array}$ & Teor de Cimento & Umidade Ótima \\
\hline Material 1 & Intermediária & $5 \%$ & $5,5 \%$ \\
\hline \multirow{3}{*}{ Material 2 } & Intermediária & $5 \%$ & $7,5 \%$ \\
\cline { 2 - 4 } & \multirow{3}{*}{ Modificada } & $5 \%$ & $6,5 \%$ \\
\cline { 2 - 4 } & & $6 \%$ & $6,5 \%$ \\
\cline { 2 - 4 } & & $7 \%$ & $7,5 \%$ \\
\hline
\end{tabular}

* Umidade ótima de compactação obtida por extrapolação

Através das curvas de compactação construídas verifica-se que a granulometria da mistura solo-brita é determinante na umidade ótima de compactação da mistura final. Conforme apresentado no gráfico da Figura 16, verifica-se que o teor de umidade para as misturas do Material 1 é inferior ao teor de umidade para as misturas com o Material 2, mantidas todas as outras variáveis. A diferença nas umidades ótimas encontradas se deve principalmente à acentuada diferença na quantidade de fração fina presente nos dois materiais (quanto maior a quantidade de finos, maior é a superfície específica do material e, consequentemente, maior a quantidade de água necessária para a compactação).

Nota-se, também, que a massa específica seca do Material 2 é superior à do Material 1. Essa diferença é causada pela diferente mineralogia dos solos em questão. O Material 2 contém um solo com presença de canga de minério, material rico em ferro e consequentemente mais pesado. 


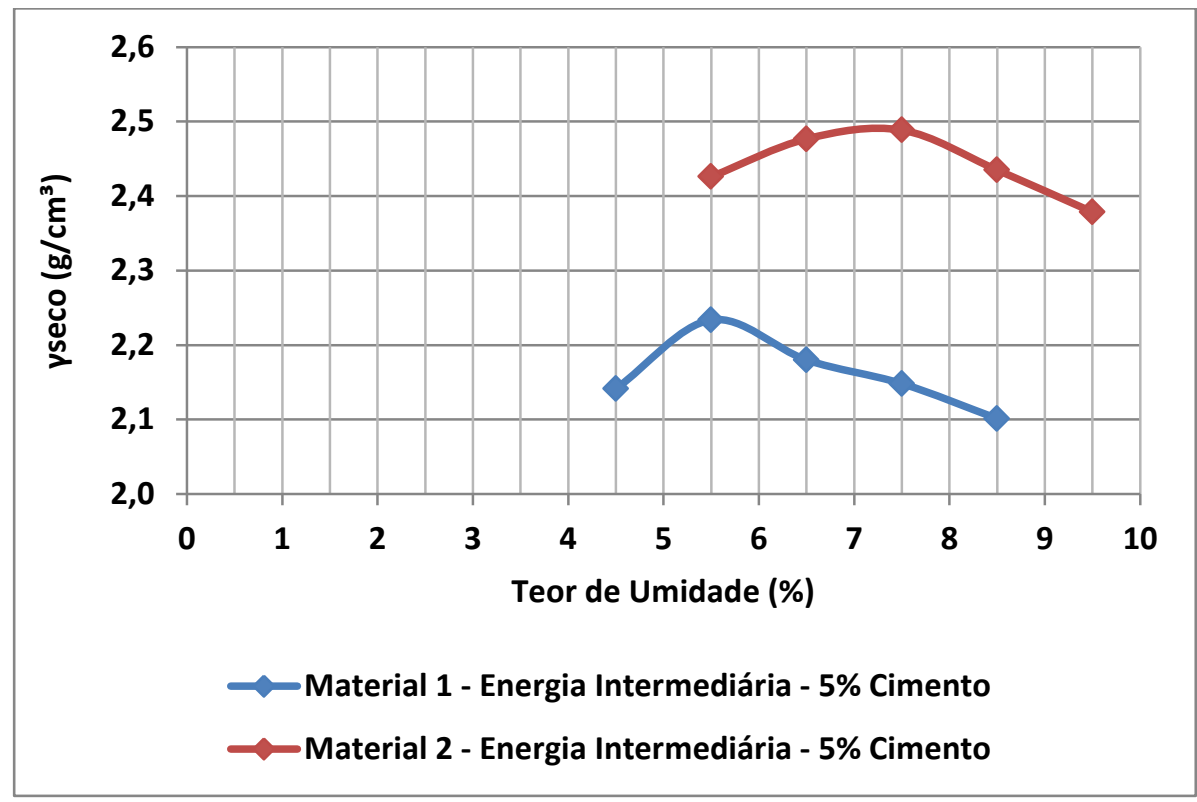

Figura 16 - Curva de compactação - Variação do material

As curvas de compactação com variação dos teores de cimento, mantendo-se constantes todas as outras condições (Figura 17), mostram que maiores teores de cimento levam a maiores teores de umidade ótima de compactação. Isso ocorre pelo aumento da fração fina do material granular, e consequentemente da sua superfície específica, além disso, ele reage com a água, dando início ao processo de hidratação e consumindo a água contida na mistura nessas reações químicas.

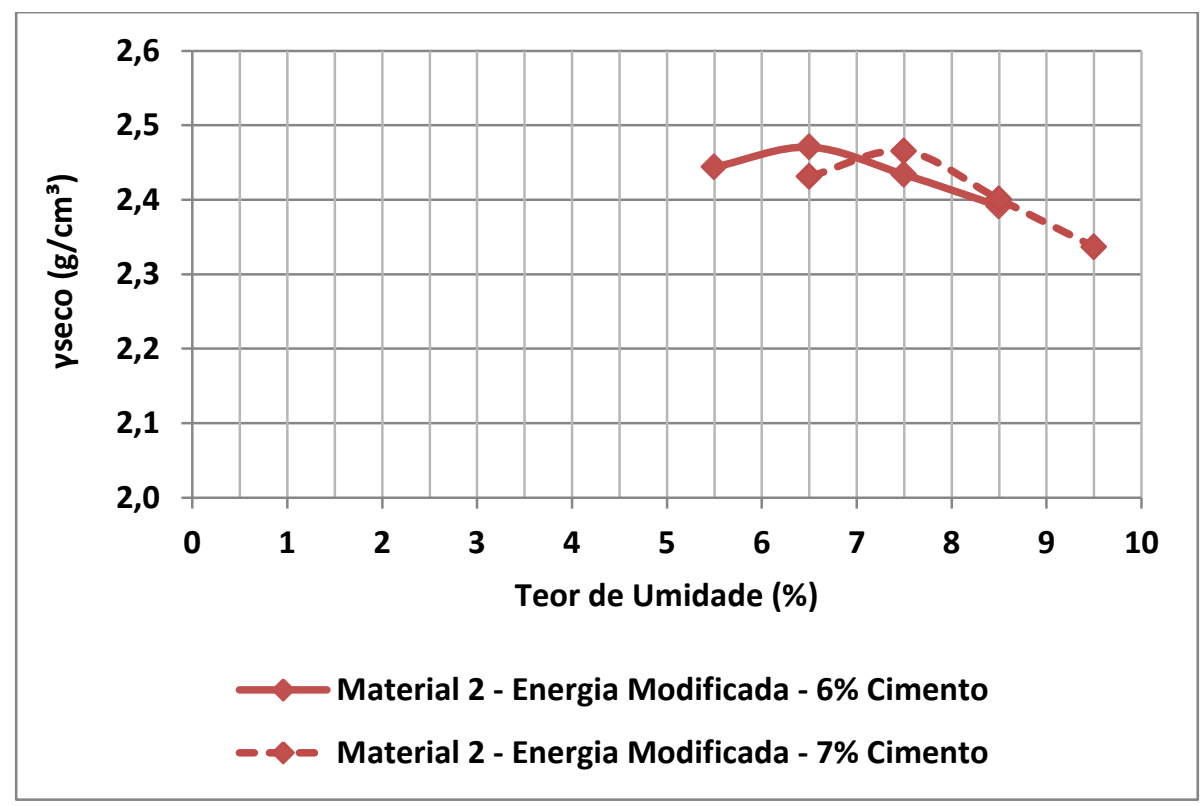

Figura 17 - Curva de compactação - Variação do teor de cimento 
Com o aumento da energia de compactação há a redução da umidade ótima de compactação das misturas (PINTO, 2007), portanto conhecendo-se a curva de compactação do Material 2 com teor de $5 \%$ de cimento e energia intermediária, definiu-se que a umidade ótima para a mesma mistura compactada na energia modificada seria $1 \%$ menor, ou seja, $6,5 \%$.

\subsection{MOLDAGEM DOS CORPOS DE PROVA}

Tanto os corpos de prova para ensaios de resistência à tração, de dimensões $10 \mathrm{~cm}$ de diâmetro por $12,73 \mathrm{~cm}$ de altura, quanto os corpos de prova de para ensaio de módulo de resiliência e resistência à compressão simples, de dimensões $10 \mathrm{~cm}$ de diâmetro por $20 \mathrm{~cm}$ de altura, foram moldados por compactação com soquete manual (Figura 18) e armazenados em saco plástico hermeticamente fechado para evitar a perda de água por evaporação, garantindo condições de hidratação do cimento (Figura 19).
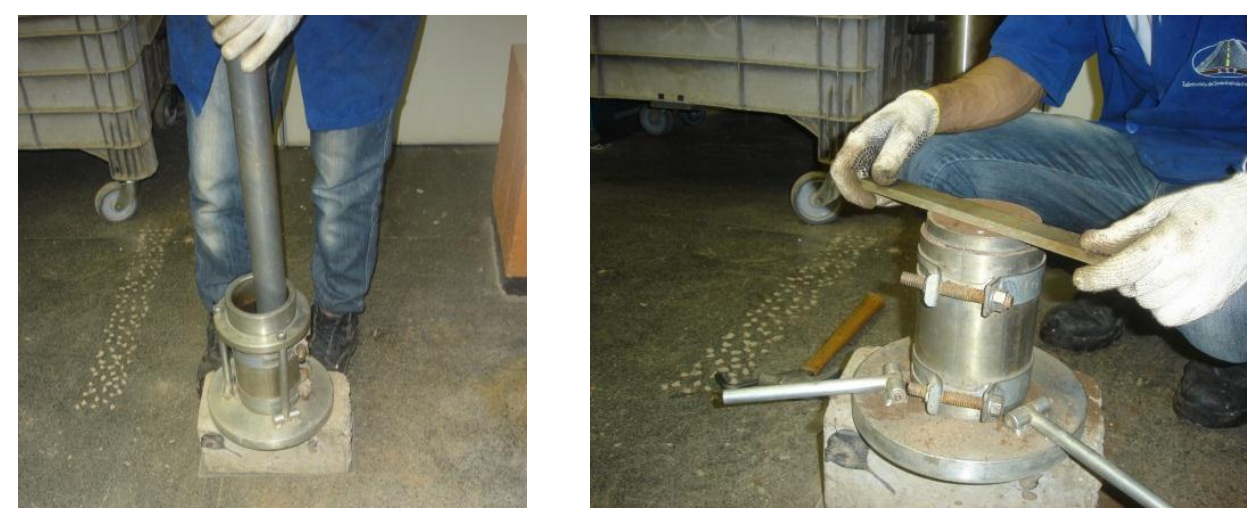

Figura 18 - Compactação do CP 10x20 cm 

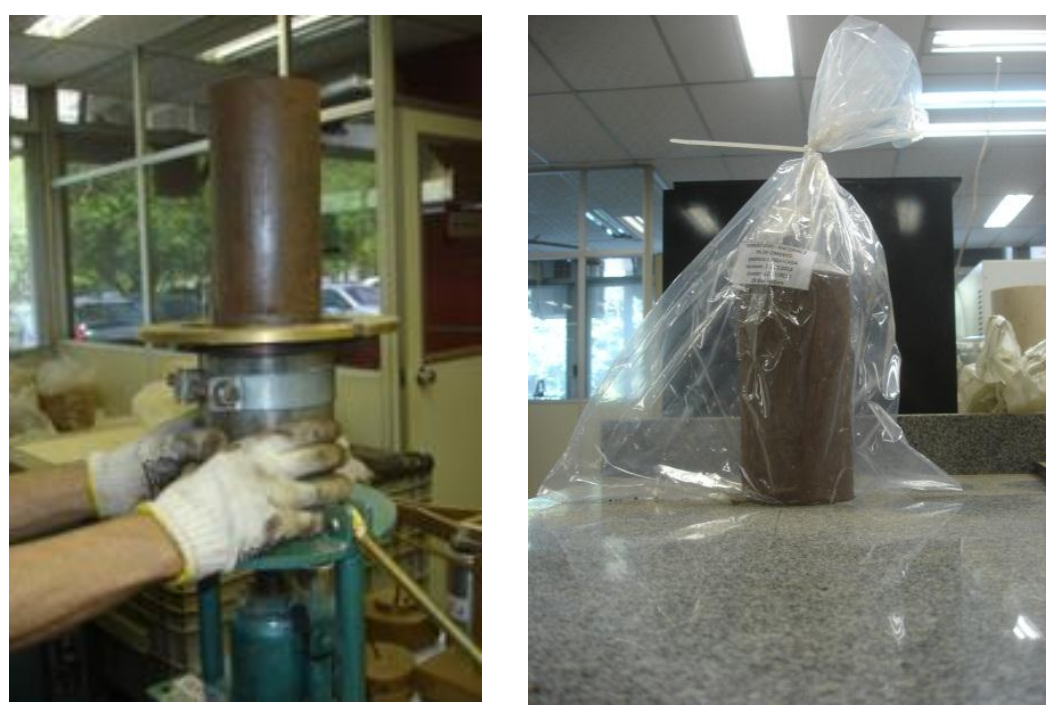

Figura 19 - Extração e armazenamento do CP 10x20 cm

Para evitar danos à impermeabilização dos corpos de prova, prevenir mudanças bruscas de temperatura ambiente e influências da luminosidade, os corpos de prova foram armazenados em caixas com tampa até a data prevista para cada ensaio.

\subsection{ESTUDO DOS MÉTODOS DE ENSAIO}

Os resultados obtidos em ensaios mecânicos são dependentes não apenas das características das amostras testadas, mas muitas vezes do método de ensaio utilizado. Os materiais objeto desse estudo, compostos por uma mistura de solo, brita e cimento, apresentam comportamento intermediário ao comportamento de um concreto e de um material granular. Não foram encontrados métodos de ensaio específicos para as misturas recicladas com cimento, nem nas especificações nacionais, nem nas especificações internacionais. Dessa forma, optou-se por realizar um estudo para verificação da influência dos métodos de ensaio nas respostas desse tipo de material, conforme abordado nos itens a seguir.

\subsubsection{Ensaio de Resistência à Tração por Compressão Diametral}

Para a determinação da resistência à tração foi selecionado o ensaio indireto por disponibilidade de equipamentos. Para o ensaio de RT de concreto a ASTM C 496 
(ASTM, 2011) define que o carregamento monotônico deve ser aplicado nas amostras através de incrementos lineares de tensão a uma taxa de 0,7 a 1,4 MPa/s, tendo sido adotada a taxa $1 \mathrm{MPa} / \mathrm{s}$. Os materiais granulares não são resistentes à tração, por isso não existe um método de ensaio aplicado para solo. Optou-se por realizar os ensaios preconizados para misturas asfálticas, ASTM D 6931 (ASTM, 2007), que define que o carregamento seja aplicado a uma taxa de deslocamento de $50 \mathrm{~mm} / \mathrm{min}$.

Foram testadas 18 amostras de mesmas dimensões e dosagem, variando-se apenas o tempo de cura e o método de ensaio. As amostras foram moldadas em cilindros com as dimensões do Proctor (10,0 x 12,7 cm), compactadas na energia intermediária, na umidade ótima de compactação e com adição de $5 \%$ de cimento. Os resultados obtidos são apresentados no gráfico da Figura 20.

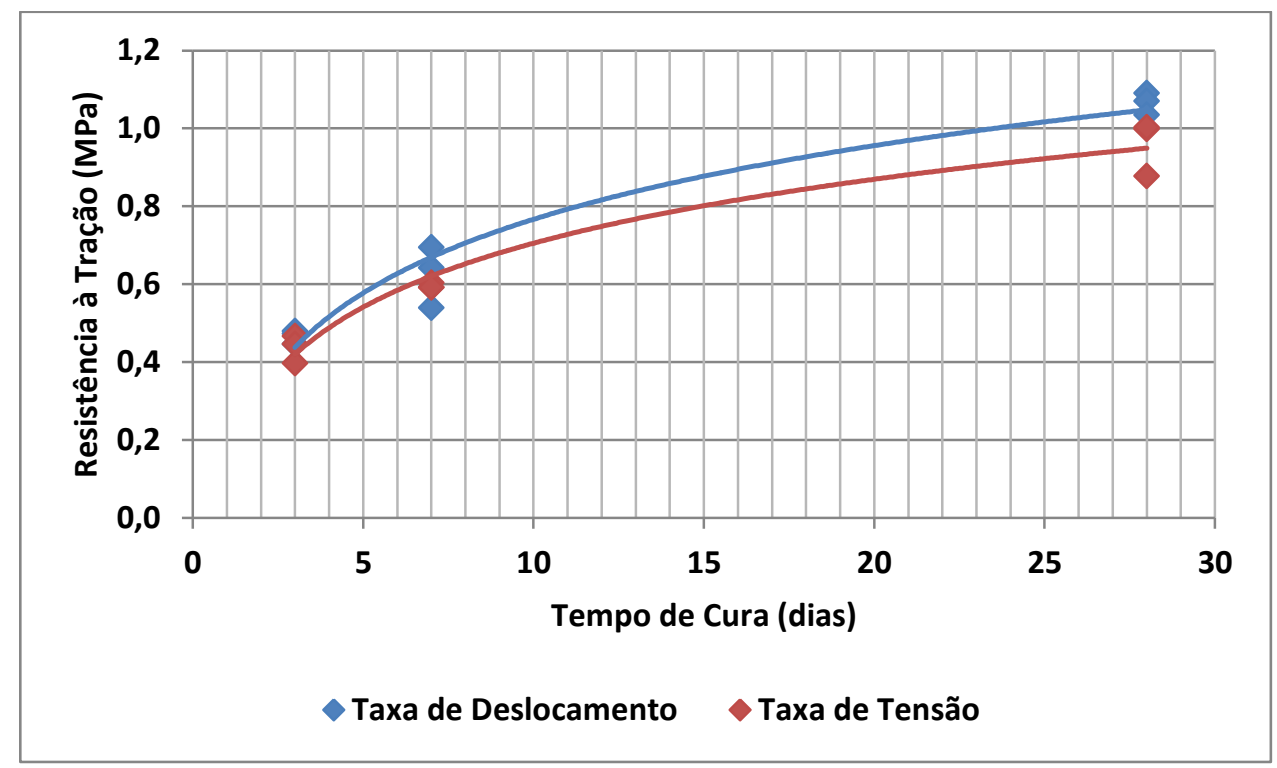

Figura 20 - Comparativo entre métodos de ensaio de RT

Verifica-se, primeiramente, os incrementos de resistência com a cura dos corpos de prova, conforme o esperado em materiais que contém cimento. Em termos da variação do método de ensaio, verificou-se que para 3 e 7 dias de cura os ensaios realizados à taxa de deslocamento controlado apresentaram valores semelhantes aos realizados à taxa de tensão controlada. Aos 28 dias, o ensaio realizado à taxa de deslocamento controlado apresentou valores médios superiores. 
Foi realizado o teste-t entre as amostras de cada método de ensaio e para cada tempo de cura. Para um nível de $95 \%$ de confiança, nenhum dos casos houve diferença estatisticamente significativa entre as médias obtidas.

Essa diferença pode ser explicada pela velocidade com que o ensaio é realizado. Os ensaios à taxa de deslocamento controlado são muito mais rápidos, durando por volta de 2 segundos enquanto os realizados a taxa de tensão controlada são mais lentos, com duração de aproximadamente de 25 segundos.

Em estudo com misturas asfálticas, Moura e Bernucci (2004) verificaram variações nos resultados obtidos para ensaios de resistência à tração com diferentes velocidades de carregamento, sendo que os ensaios rápidos (50 $\mathrm{mm} / \mathrm{min}$ ) chegaram a valores de RT entre 100 e $150 \%$ superiores aos obtidos nos ensaios lentos (1 mm/min).

Silva et al. (2004) realizaram um estudo semelhante para corpos de prova de concreto de cimento Portland. Os resultados para ensaios rápidos de ruptura à compressão (6,5 MPa/s) apresentaram pouca variação em relação aos resultados para ensaios lentos $(0,5 \mathrm{MPa} / \mathrm{s})$, porém apresentaram a mesma tendência de maiores valores de resistência para maiores velocidades de ensaios.

\subsubsection{Ensaio de Resistência à Compressão}

Os ensaios de resistência à compressão simples também foram realizados por dois procedimentos de ensaio distintos. A ASTM C 39 (ASTM, 2012) define que em ensaios de RCS de corpos de prova de concreto a carga deve ser aplicada nas amostras através de incrementos lineares de tensão a uma taxa de 0,25 MPa/s. Para solos, a ASTM D 2166 (ASTM, 2006) preconiza que esse carregamento seja aplicado a uma taxa de deslocamento de $1 \mathrm{~mm} / \mathrm{min}$.

Assim, como nos ensaios de resistência à tração, foram testadas 18 amostras de mesmas dimensões e dosagem, variando-se apenas o tempo de cura e o método de ensaio. As amostras foram moldadas em cilindros com as dimensões do Proctor 
(10,0 x 12,7 cm), compactadas na energia intermediária, na umidade ótima de compactação e com adição de $5 \%$ de cimento. Os resultados obtidos são apresentados no gráfico da Figura 21.

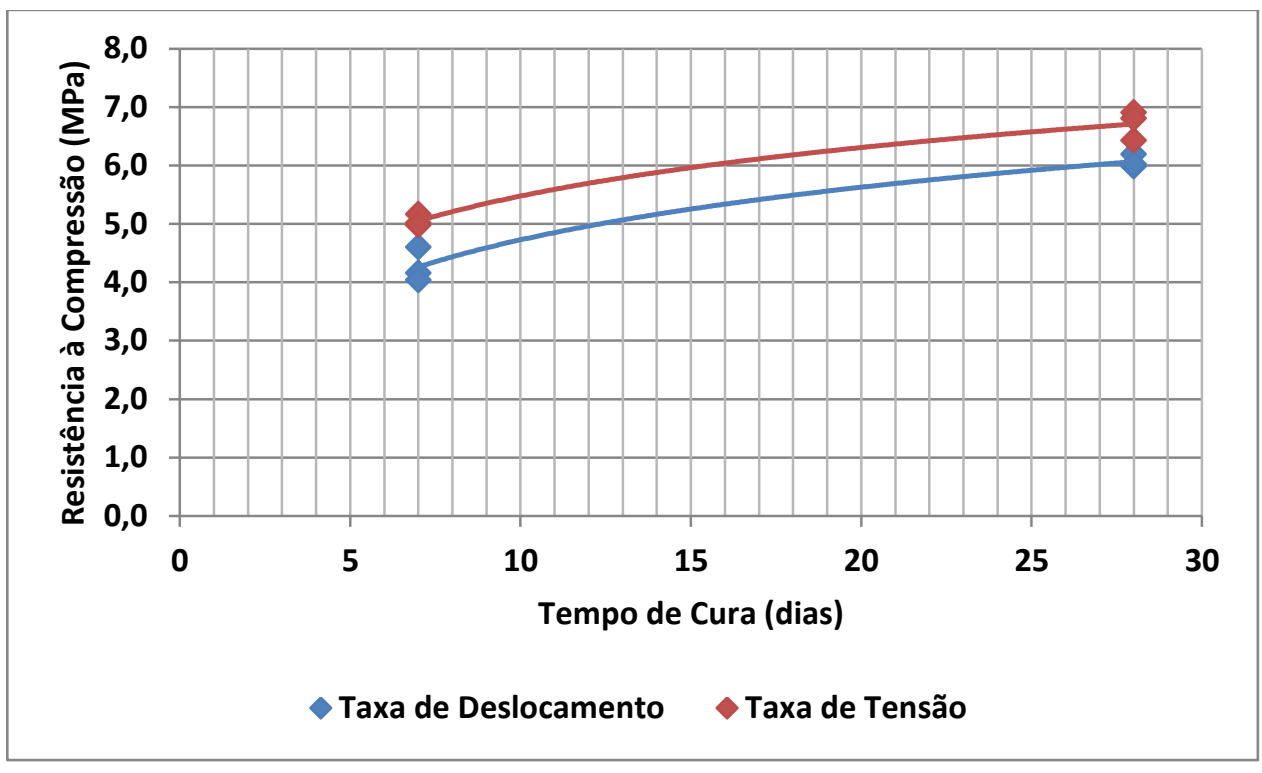

Figura 21 - Comparativo entre métodos de ensaio de RC

Novamente verificou-se o acréscimo de resistência decorrente da cura. Contudo, houve a inversão de resultados no que diz respeito ao método utilizado. Os corpos de prova ensaiados à taxa de deslocamento controlado apresentaram resultados inferiores àqueles ensaiados à tensão controlada.

Os ensaios feitos à taxa de tensão controlada tiveram duração média de 20 segundos enquanto os ensaios realizados à taxa de deslocamento controlado tiveram duração média de 150 segundos. Dessa forma, atribui-se essa inversão justamente a inversão nos tempos de ensaio de acordo com os métodos adotados.

Portanto, assim como nos ensaios de resistência à tração, os ensaios de resistência à compressão apresentam resultados superiores quando realizados a velocidades maiores uma vez que não há tempo para a acomodação do material durante o ensaio. Quando submetidas ao teste-t as médias para os dois métodos de ensaio, para cada tempo de cura, se mostraram estatisticamente diferentes para um nível de confiança de 95\%, podendo-se assim afirmar que houve diferença significativa entre os resultados obtidos para diferentes métodos de ensaio. 
A fim de se compreender melhor os efeitos do tempo de carregamento, as curvas de tensão $x$ deformação foram traçadas para os dois tempos de cura e nos dois métodos de ensaio em questão. Essas curvas são apresentadas nos gráficos da Figura 22, para 7 dias de cura, e Figura 23, para 28 dias de cura.

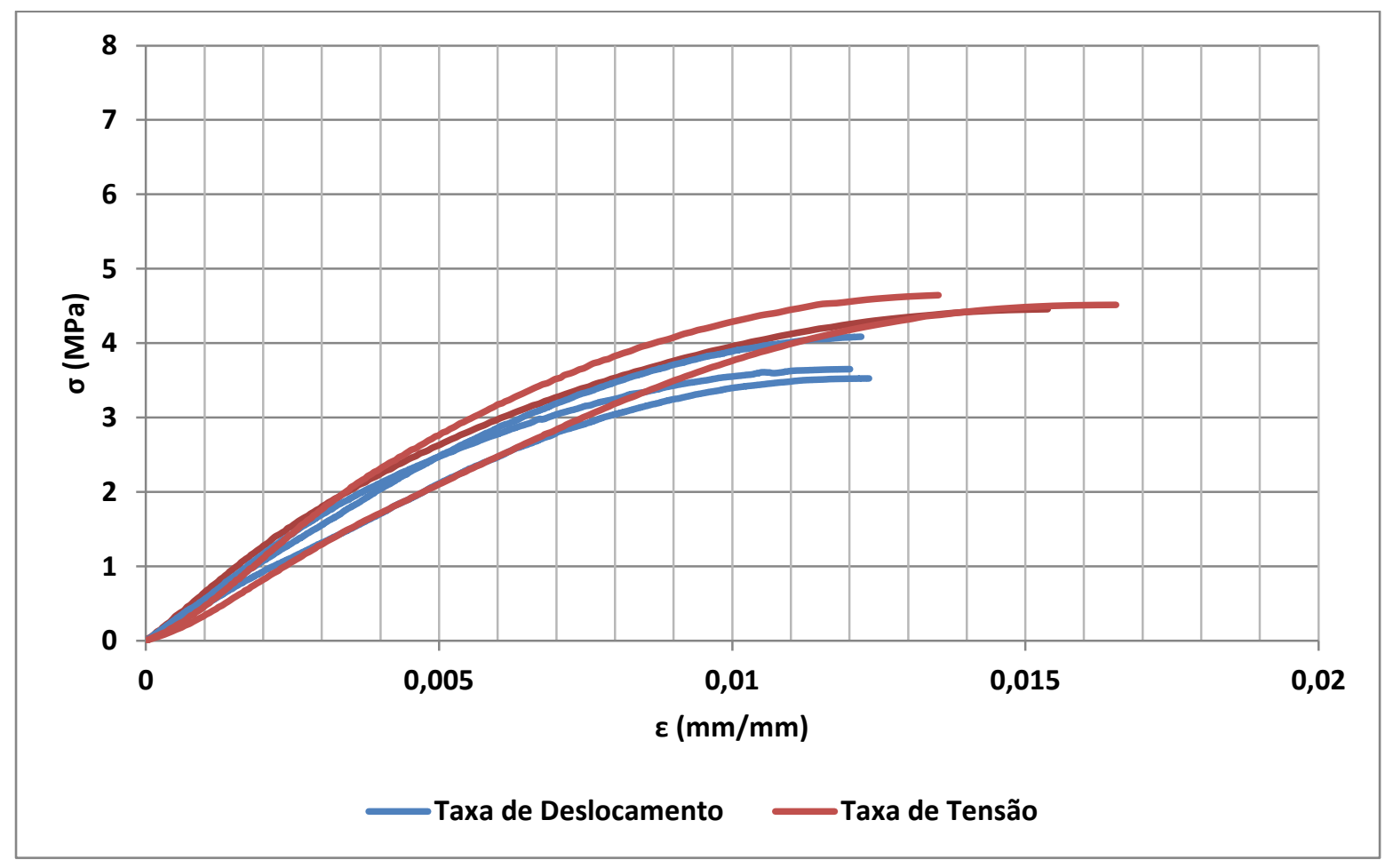

Figura 22 - Curva tensão $x$ deformação para CPs com 7 dias de cura

Verifica-se que para 7 dias de cura os ensaios realizados à taxa de tensão controlada (mais rápido) apresentaram valores superiores de resistência e ruptura com maiores níveis de deformação, indicando que o ensaio mais lento foi menos severo. 


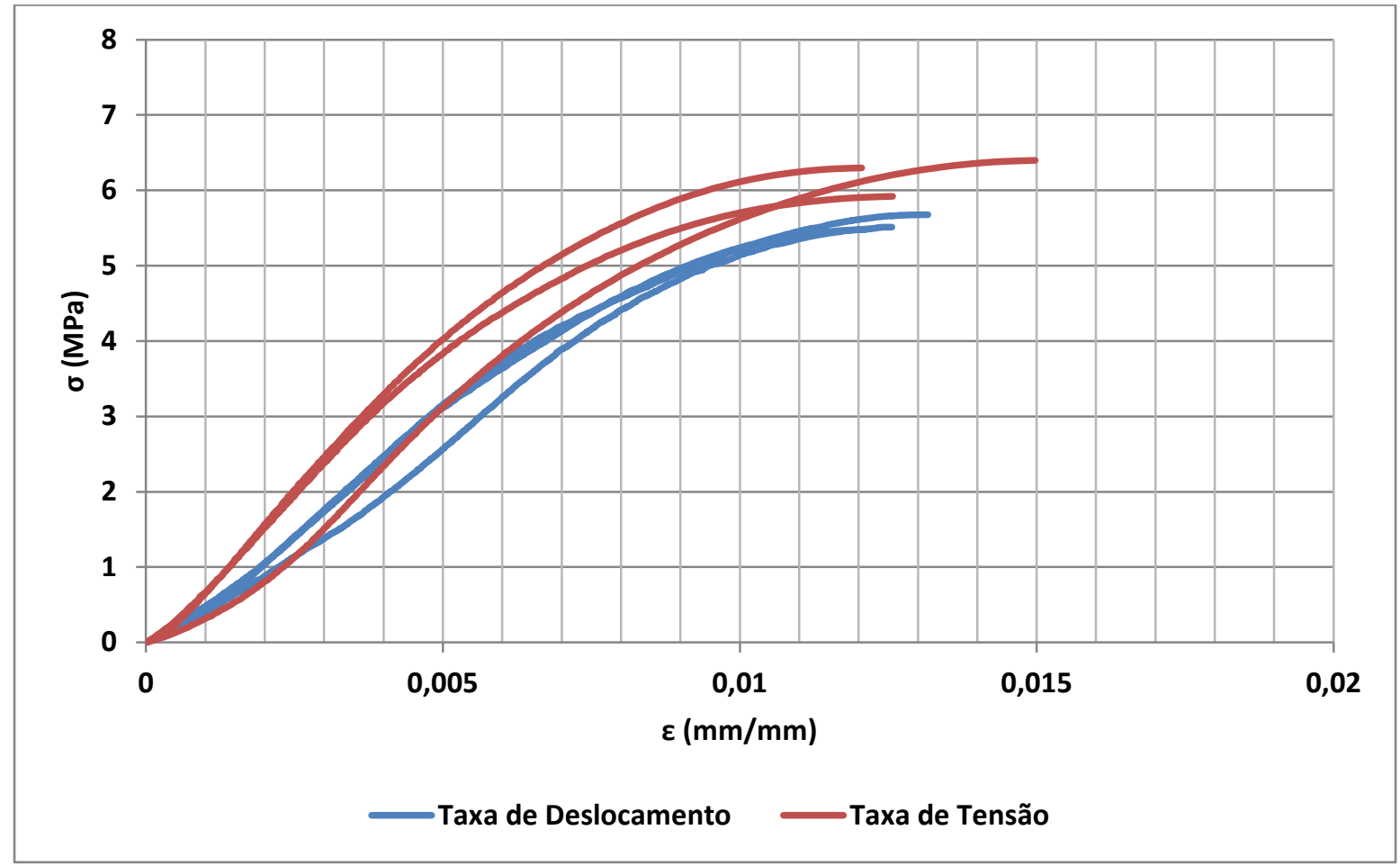

Figura 23 - Curva tensão x deformação para CPs com 28 dias de cura

Para os ensaios realizados aos 28 dias de cura verificou-se que a ruptura ocorreu para níveis iguais de deformação para os dois métodos de ensaio. Isso pode ter ocorrido devido ao fim do processo de hidratação do cimento, estando os corpos de prova mais enrijecidos e reduzindo os efeitos da acomodação da amostra ao longo do ensaio.

\subsubsection{Ensaio de Módulo de Resiliência e Módulo de Elasticidade}

A rigidez de dado material é expressa pelo módulo de resiliência quando se trata de um material granular e módulo de elasticidade quando se trata de um concreto. Os materiais investigados nesse estudo foram avaliados por meio dos dois métodos de ensaio.

Em ambos os ensaios os corpos de prova cilíndricos são solicitados axialmente e são medidas as deformações decorrentes dessa solicitação. Os ensaios diferem quanto às magnitudes e formas de carregamentos aplicados e quanto à presença de tensão de confinamento (presente apenas no caso do módulo de resiliência). 
O ensaio de Módulo de Resiliência consiste da aplicação de quinze combinações de tensões, com variações nas tensões desviadoras e de confinamento. O valor do Módulo de Resiliência é obtido para cada uma dessas combinações, resultando em uma curva de MR versus Tensão de Confinamento. As cargas axiais são aplicadas de forma cíclica, onde o período tem duração de 1 segundo, sendo que a carga é aplicada durante 0,1 segundos (Figura 24).

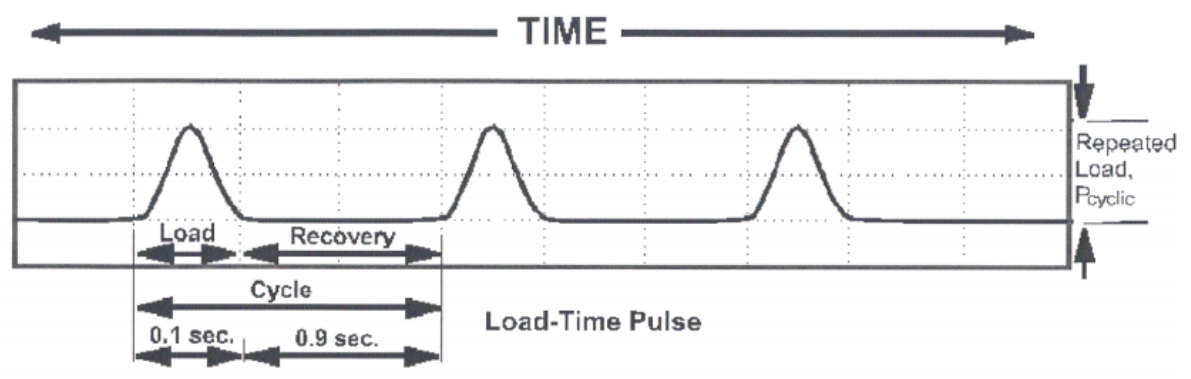

Figura 24 - Ensaio de MR - Aplicação de Carga (Adaptado da AASHTO T 307)

O ensaio de Módulo de Elasticidade, menos consagrado para os materiais de pavimentação asfáltica, consiste da aplicação de três ciclos de carregamento e descarregamento no corpo de prova, sendo que cada ciclo tem período de 240 segundos, conforme a curva ilustrada na Figura 25. O patamar inferior da curva é definido como $0,5 \mathrm{MPa}$, o patamar superior é definido como $30 \%$ da tensão de ruptura a compressão do material. A medida de tensão e deformação dos corpos de prova é feita no quarto ciclo de carregamento e descarregamento. Após a tomada dos dados, o corpo de prova é carregado até sua ruptura.

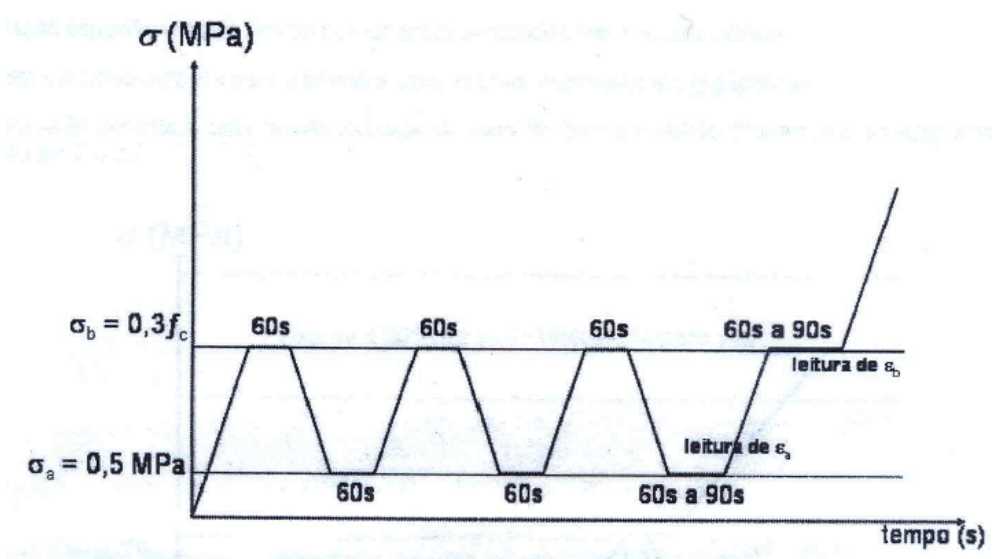

Figura 25 - Ensaio de ME - Aplicação de Carga (Adaptado da NBR 8522) 
Os gráficos abaixo (Figura 26 e Figura 27) são resultados dos ensaios realizados em um mesmo corpo de prova durante o ensaio de MR e ME, respectivamente. Nesses gráficos verifica-se que a magnitude de carga aplicada no ensaio de módulo de elasticidade é dez vezes maior que a aplicada no ensaio de módulo de resiliência. Verifica-se também que a forma e tempo de aplicação dessas cargas são bastante distintos, sendo $0,1 \mathrm{~s}$ para o ensaio de módulo de resiliência e $60 \mathrm{~s}$ para o ensaio de módulo de elasticidade.

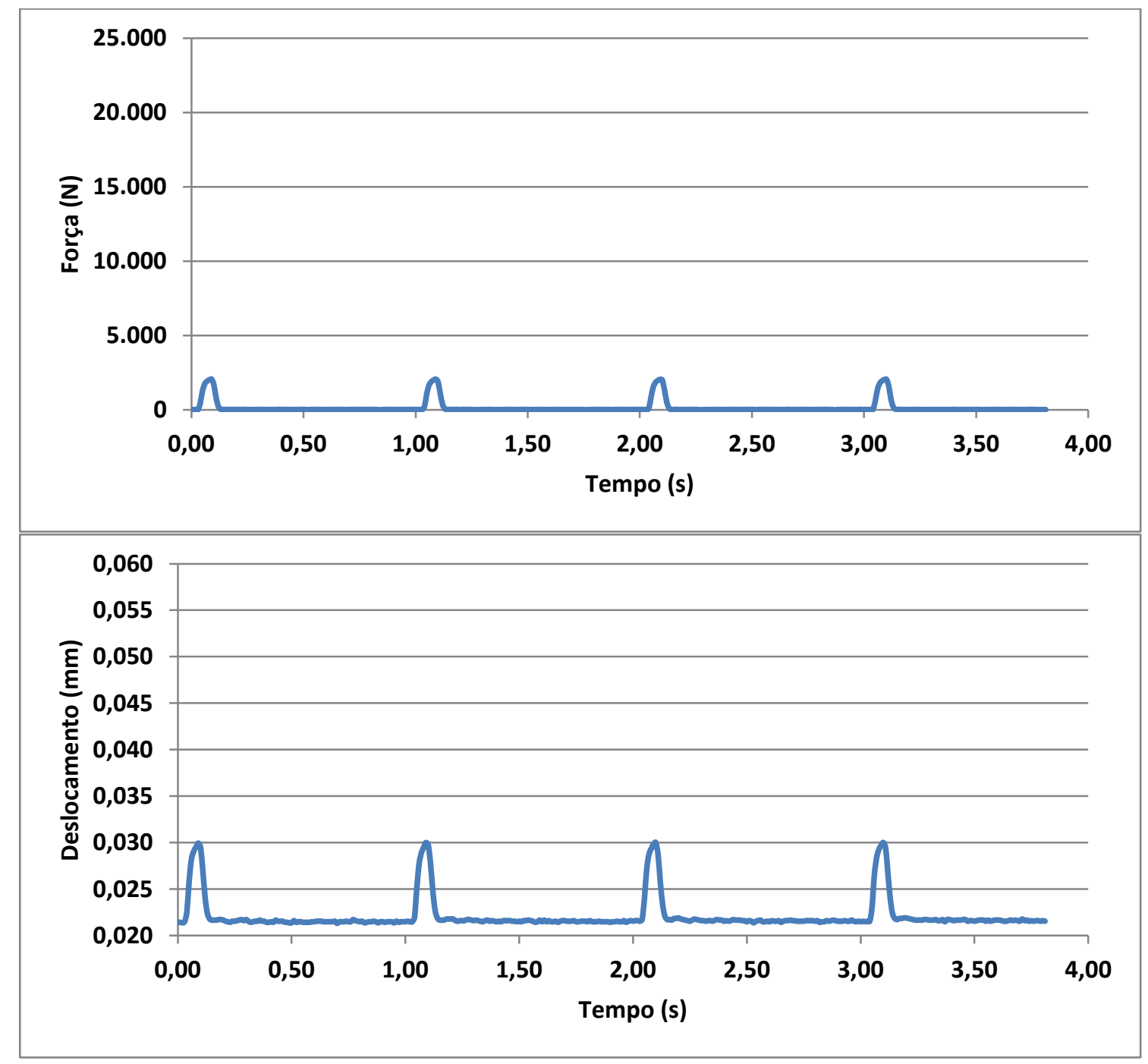

Figura 26 - Ciclo de aplicação de cargas no ensaio de módulo de resiliência 


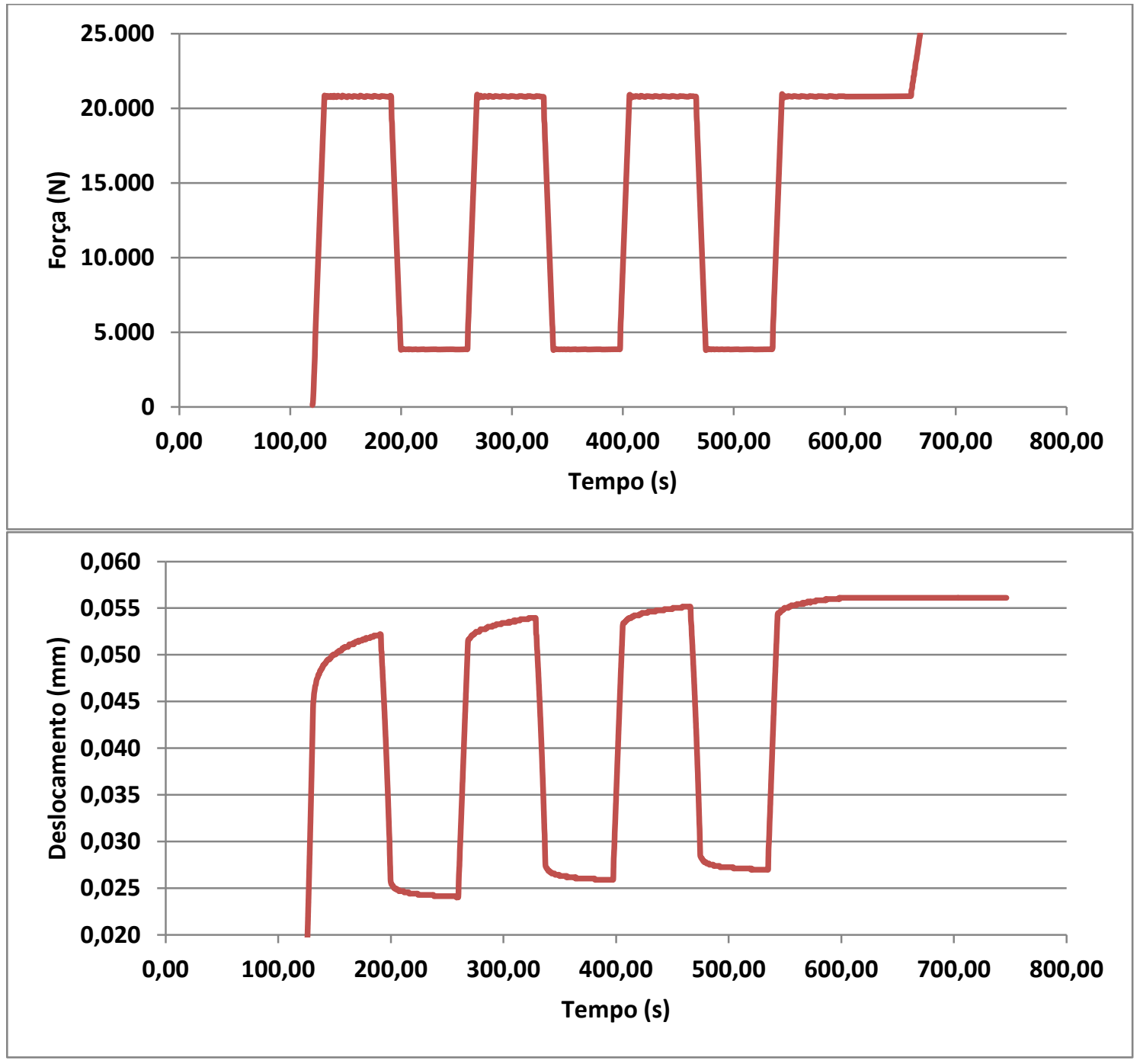

Figura 27 - Ciclo de aplicação de cargas no ensaio de módulo de elasticidade

O ensaio de módulo de elasticidade, por apresentar carregamentos muito superiores, é feito na região de dano do material, fazendo dele um ensaio destrutivo. O módulo de resiliência, por sua vez, é um ensaio não destrutivo e não deve provocar dano nos corpos de prova ao longo do ensaio. Os gráficos da Figura 28 e da Figura 29 apresentam os ciclos do ensaio de MR e ME, respectivamente, onde é possível observar a mudança de comportamento do corpo de prova durante o ensaio de ME. O fato dos ciclos não ocorrerem na mesma posição, ou seja, a curva apresentar formato de espiral no ensaio de módulo de elasticidade, é resultado do dano sofrido pelo corpo de prova durante o ensaio. 


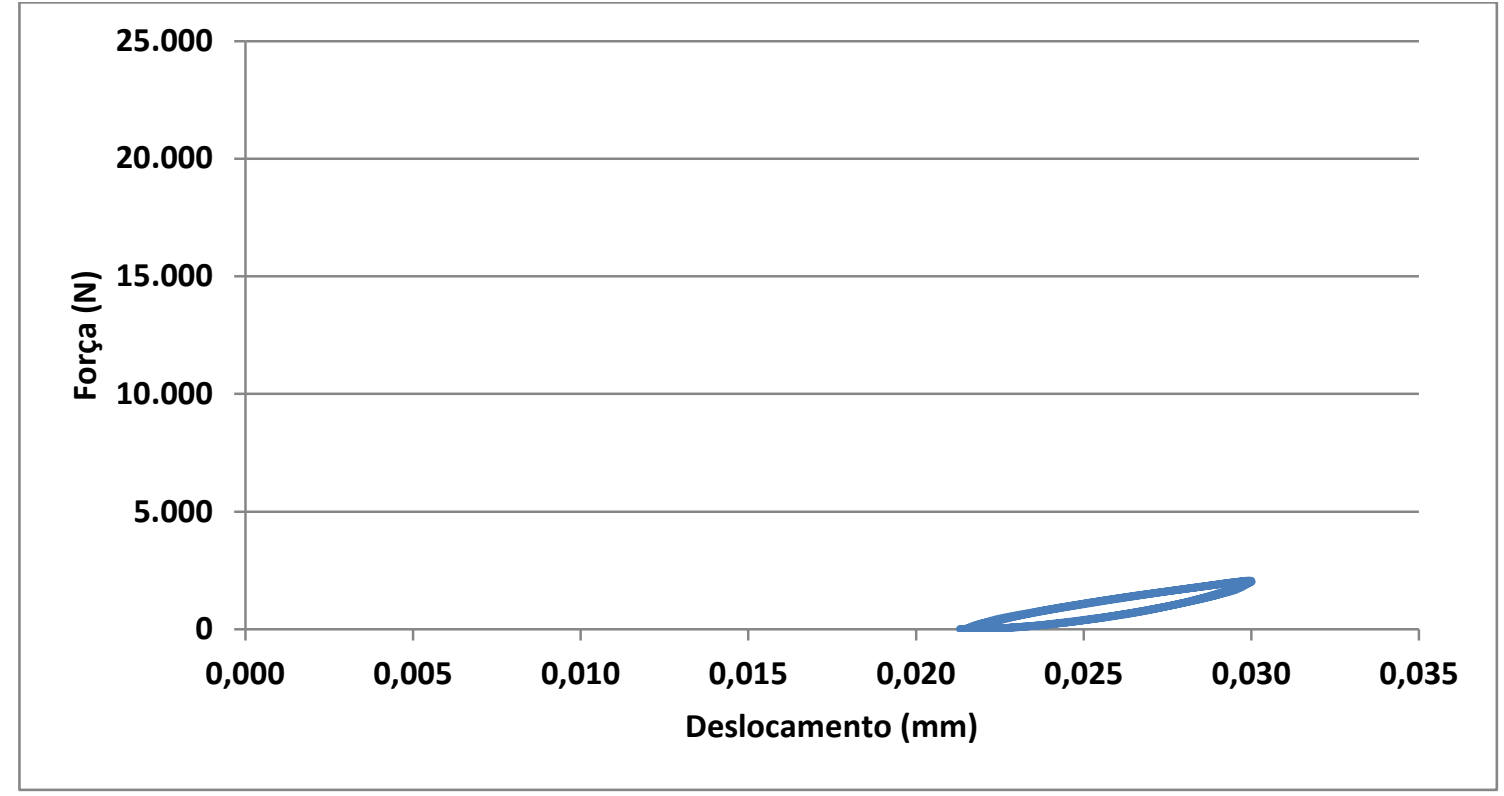

Figura 28 - Ciclos de carregamento e descarregamento - Módulo de resiliência

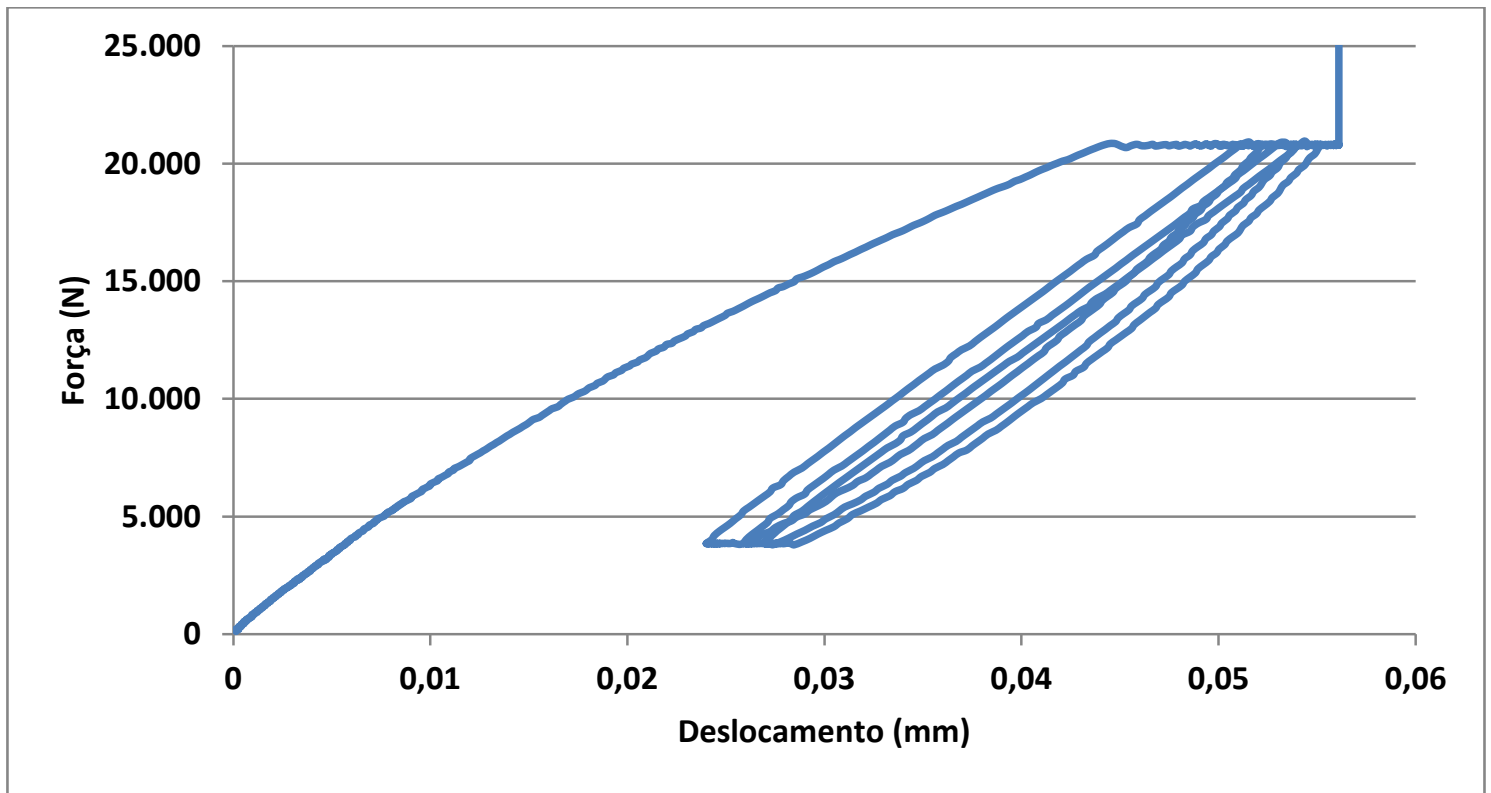

Figura 29 - Ciclos de carregamento e descarregamento - Módulo de elasticidade

Tendo em vista que o ensaio de módulo de resiliência não danifica as amostras, quatro corpos de prova foram submetidos tanto ao ensaio de módulo de resiliência, quanto ao ensaio de módulo de elasticidade, proporcionando assim uma comparação direta entre os resultados dos dois métodos de ensaio. Os resultados obtidos são apresentados no gráfico da Figura 30. Esses resultados são referentes a dois corpos de prova preparados com adição de $5 \%$ de cimento moldados na energia modificada e ensaiados após 28 dias de cura. 


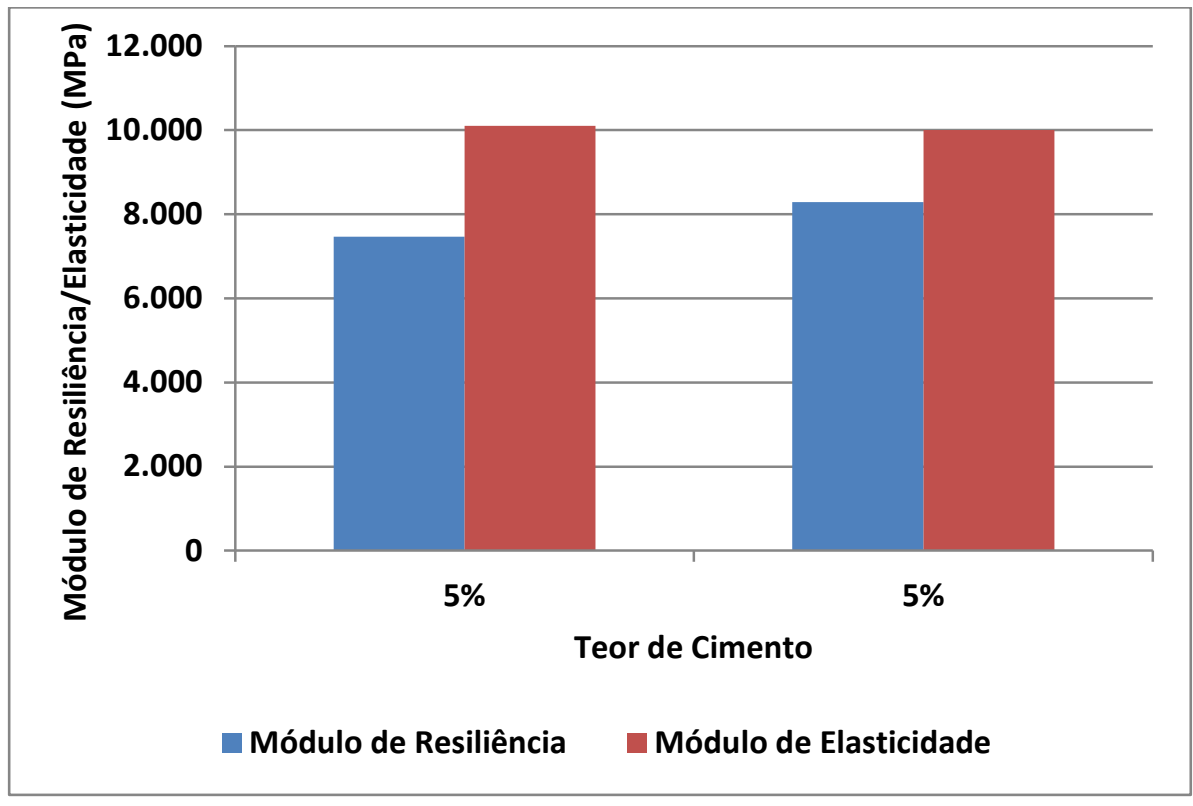

Figura 30 - Resultados da comparação entre MR e ME

No ensaio de módulo de elasticidade a menor carga aplicada no corpo de prova (patamar inferior da curva) é de aproximadamente $3 \mathrm{kN}$, imprimindo uma deformação inicial (acomodação do corpo de prova). A medida de deformações é feita a partir da deformação inicial até a deformação máxima, causada pela tensão máxima de carregamento (20 kN, aproximadamente). Em contrapartida, a maior carga aplicada no ensaio de módulo de resiliência é de aproximadamente $2 \mathrm{kN}$ e não existe carga de acomodação, sendo o deslocamento total considerado nos cálculos. Como os módulos são uma relação entre tensão/deformação, maiores deformações resultam em menores módulos. Acredita-se que essa seja a principal causa das diferenças nos resultados.

Verifica-se que os valores obtidos para o módulo de elasticidade são superiores aos obtidos para o módulo de resiliência, mesmo esse contando com tensão confinante. Em estudo com seis tipos distintos de solos coesivos Davich et al. (2004) obteve essa tendência de resultados quando comparando essas duas medidas de rigidez. O autor atribui essas diferenças ao fato do ensaio usado para determinar o módulo de elasticidade utilizar leituras de deformações pontuais com strain gage, muito pequenas por definição, enquanto o ensaio de módulo de resiliência utiliza leituras de LVDT, que medem o deslocamento em todo o comprimento do corpo de prova. 
Os ensaios de módulo de resiliência e módulo de elasticidade, apresentados também apresentam diferenças significativas em relação ao ponto de medida de deformações (Figura 31 e Figura 32). Os ensaios de módulo de elasticidade fazem essas leituras em uma região de $10 \mathrm{~cm}$ de comprimento, no centro do corpo de prova, o que resulta em menores deformações. Camargo et al. (2012) verificou as variações de resultados de módulo de resiliência quando se variava a instrumentação externa (medindo deformações em todo o comprimento do corpo de prova) e interna (medindo deformações no terço médio do corpo de prova). Esse estudo concluiu que os módulos de resiliência são maiores quando as deformações são medidas internamente e a diferença encontrada entre as medidas é tão maior quanto maior é a rigidez do material.

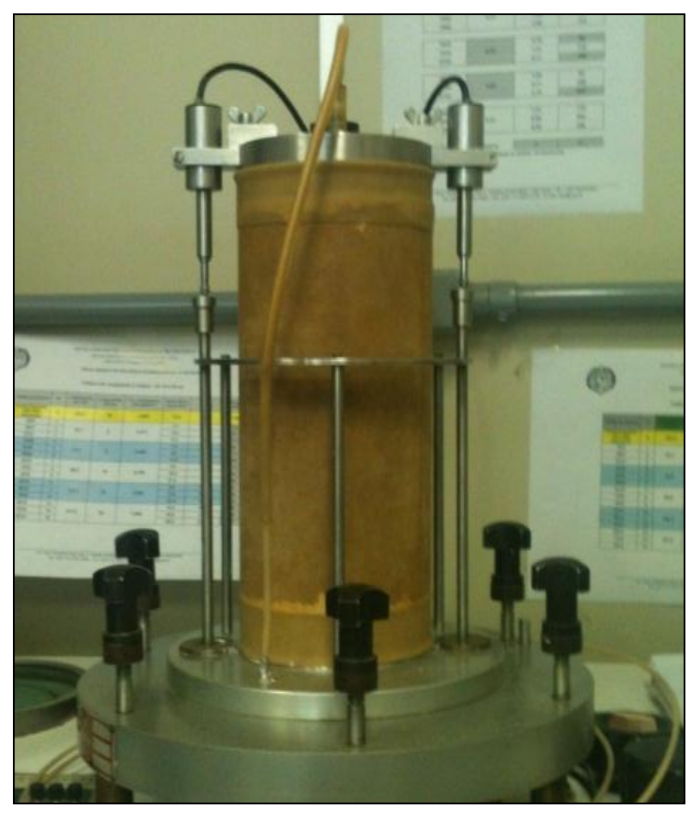

Figura 31 - Instrumentação no ensaio de MR

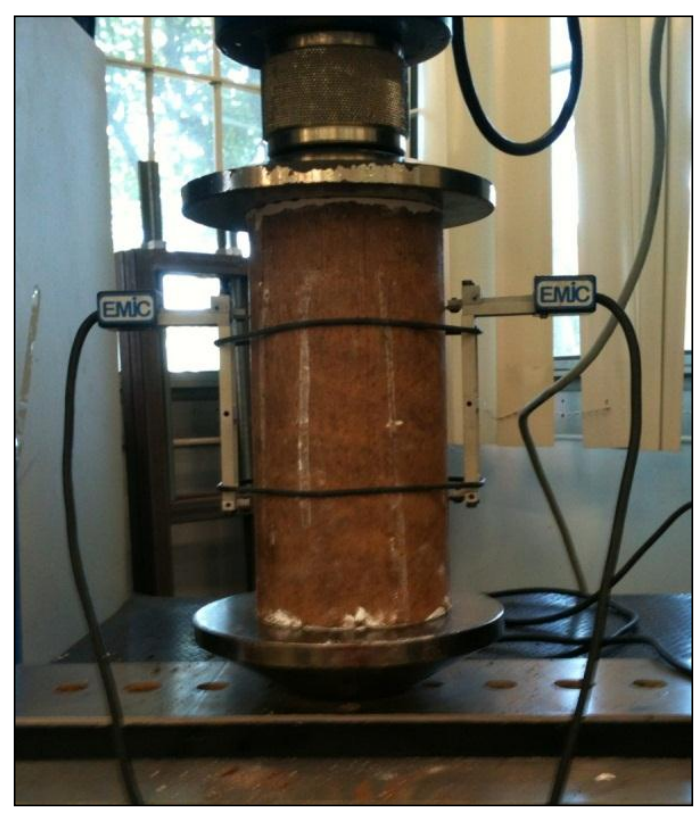

Figura 32 - Instrumentação no ensaio de ME

\subsection{ENSAIOS MECÂNICOS}

Com o objetivo de se quantificar a influência das diferentes variáveis que compõem a mistura reciclada com cimento, as cinco misturas testadas foram comparadas através de resultados de ensaios mecânicos. Os parâmetros mecânicos avaliados 
foram resistência à tração indireta, resistência à compressão simples e módulo de resiliência triaxial.

Os ensaios de ruptura foram selecionados de acordo com os resultados obtidos no item 4.4, respeitando-se o critério de realizar o ensaio com aplicação lenta de carregamento de modo que ocorra menos dano nos corpos de prova. Assim, as normas utilizadas nos ensaios são apresentadas abaixo.

(i) Resistência à Tração: determinada de acordo com a ASTM C496 (ASTM, 2011) em ensaio de ruptura por compressão diametral. Os corpos de prova utilizados nesses ensaios foram moldados em cilindros Proctor por compactação manual e armazenados em recipientes hermeticamente fechados respeitando sua cura.

(ii) Resistência à Compressão Simples: determinada de acordo com a ASTM D2166 (ASTM, 2006) para ensaio de resistência à compressão simples de solos coesivos. Os corpos de prova utilizados nesses ensaios foram moldados em cilindros de $10 \mathrm{~cm}$ de diâmetro e $20 \mathrm{~cm}$ de altura, por compactação manual, e armazenados em recipientes impermeáveis respeitando sua cura.

(iii) Módulo de Resiliência Triaxial: determinado de acordo com a AASHTO T 307 (AASHTO, 2011) em ensaio para a determinação de módulo de resiliência de solos e materiais granulares. Os corpos de prova utilizados foram os mesmos moldados para o ensaio de resistência à compressão simples.

As variáveis analisadas, conforme apresentado nos subitens a seguir, foram: (i) tipo de material reciclado; (ii) teor de cimento; (iii) energia de compactação; e (iv) tempo de cura. 


\subsubsection{Comparação entre Materiais Reciclados}

Nesse grupo de ensaios foram avaliadas as diferenças entre os dois materiais estudados através do ensaio de resistência à tração. Para tanto foram moldados corpos de prova dos dois materiais, com as características apresentadas na Tabela 6.

Tabela 6 - Características dos corpos de prova

\begin{tabular}{|c|c|c|c|}
\hline & Teor de Cimento & Teor de Umidade & $\begin{array}{c}\text { Energia de } \\
\text { Compactação }\end{array}$ \\
\hline Material 1 & $5 \%$ & Ótima $(5,5 \%)$ & Intermediária \\
\hline Material 2 & $5 \%$ & Ótima $(7,5 \%)$ & Intermediária \\
\hline
\end{tabular}

\section{a) Resistência à Tração}

Foram ensaiados três corpos de prova para cada condição de tempo de cura, para cada material testado, totalizando dezoito copos de prova. Os resultados obtidos são apresentados na Figura 33, onde é possível verificar as diferenças entre valores de resistência à tração.

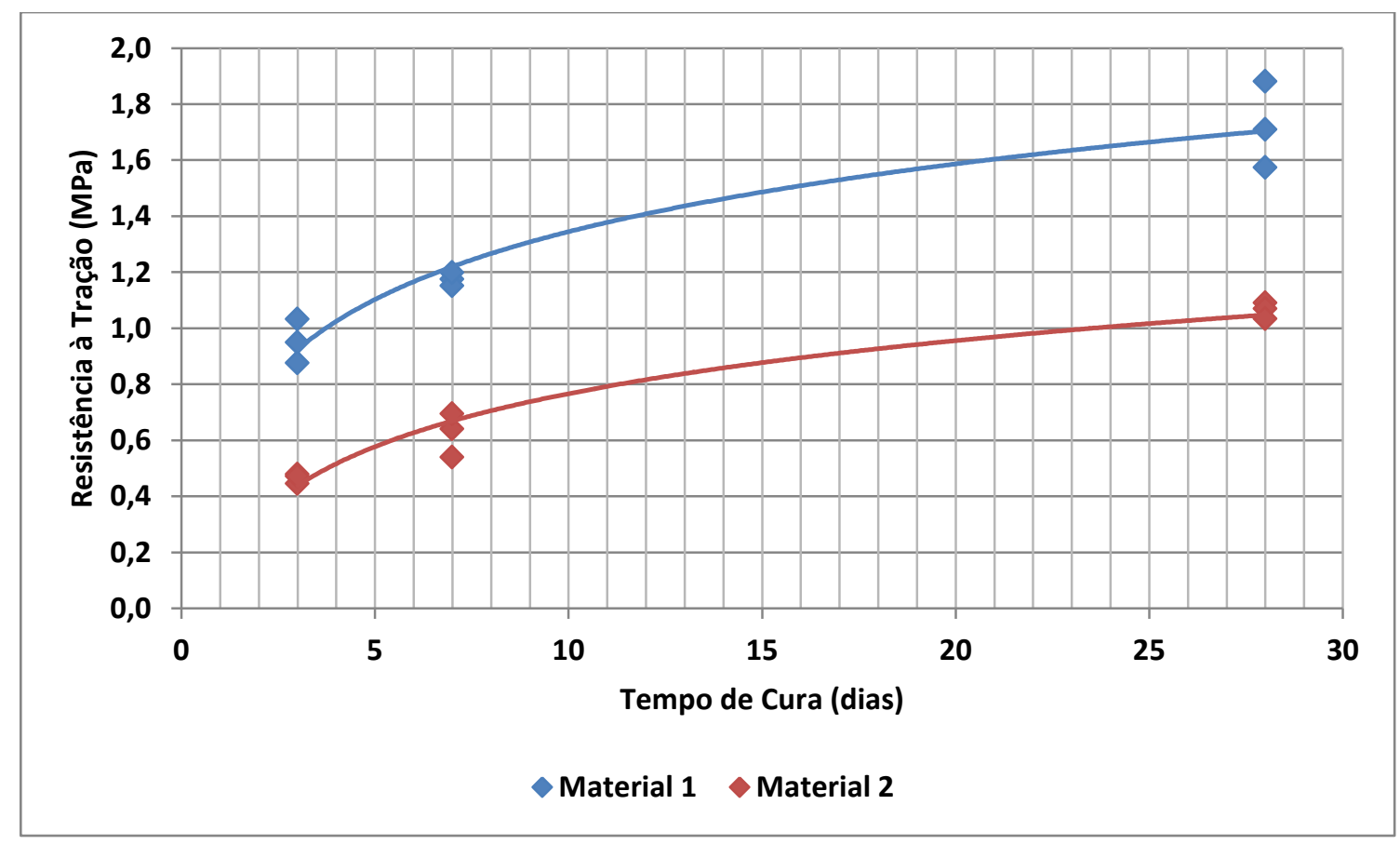

Figura 33 - Resultados de resistência à tração - Variação de materiais 
Os materiais diferem nos valores de resistência obtidos: tendo o Material 1 aos 28 dias de cura apresentado resistência à tração média de 1,64 MPa, enquanto o Material 2 apresentou 1,06 MPa. Essa variação pode ser explicada pela diferença granulométrica encontrada entre os dois materiais, onde 0 material com granulometria mais fina e maior percentual de solo (Material 2) apresentou resistência mais baixa.

O DER/SP específica na instrução de projeto para pavimentos semirrígidos (DER/SP, 2006) que a resistência à tração para misturas de BGTC deve ser superior a 0,7 MPa aos 28 dias de cura, não apresentando limites para misturas de solo-britacimento. Verificou-se que as duas misturas recicladas respeitaram 0 limite estabelecido para BGTC, sendo que a Mistura 1, tratada nesse trabalho como solobrita-cimento, apresentou resultados comparáveis às misturas de concreto compactado com rolo (resistência à tração superior a 1,5 MPa), de acordo com a mesma especificação.

Em pesquisa com materiais virgens, Balbo (2002) obteve valores de resistência à tração de 0,7 MPa para uma mistura de solo-cimento com adição de $9 \%$ de cimento. Bechara em estudo com misturas de solo-cimento com 6\% de teor de cimento obteve valores de resistência à tração entre 0,6 MPa e 0,8 MPa (BECHARA et al., 2010). Portanto verifica-se que o Material 2 apresenta valores de resistência comparáveis, se não superiores, às misturas de solo-cimento virgens.

Considera-se ainda que o teor de $5 \%$ de cimento foi insuficiente para garantir comportamento semelhante entre os dois materiais. Isso ocorre, pois o cimento age apenas na fração fina (solo) do material, e como o Material 1 apresenta quantidade inferior de solo em sua composição a relação cimento/solo nesse material é superior à que ocorre no Material 2.

\section{b) Resistência à Compressão}

Os valores de resistência à compressão simples foram obtidos apenas para os tempos de cura de 7 e 28 dias, previstos nas normas brasileiras e internacionais. 
Assim foram ensaiados doze corpos de prova, três para cada tempo de cura de cada material. Esses resultados são apresentados na Figura 34.

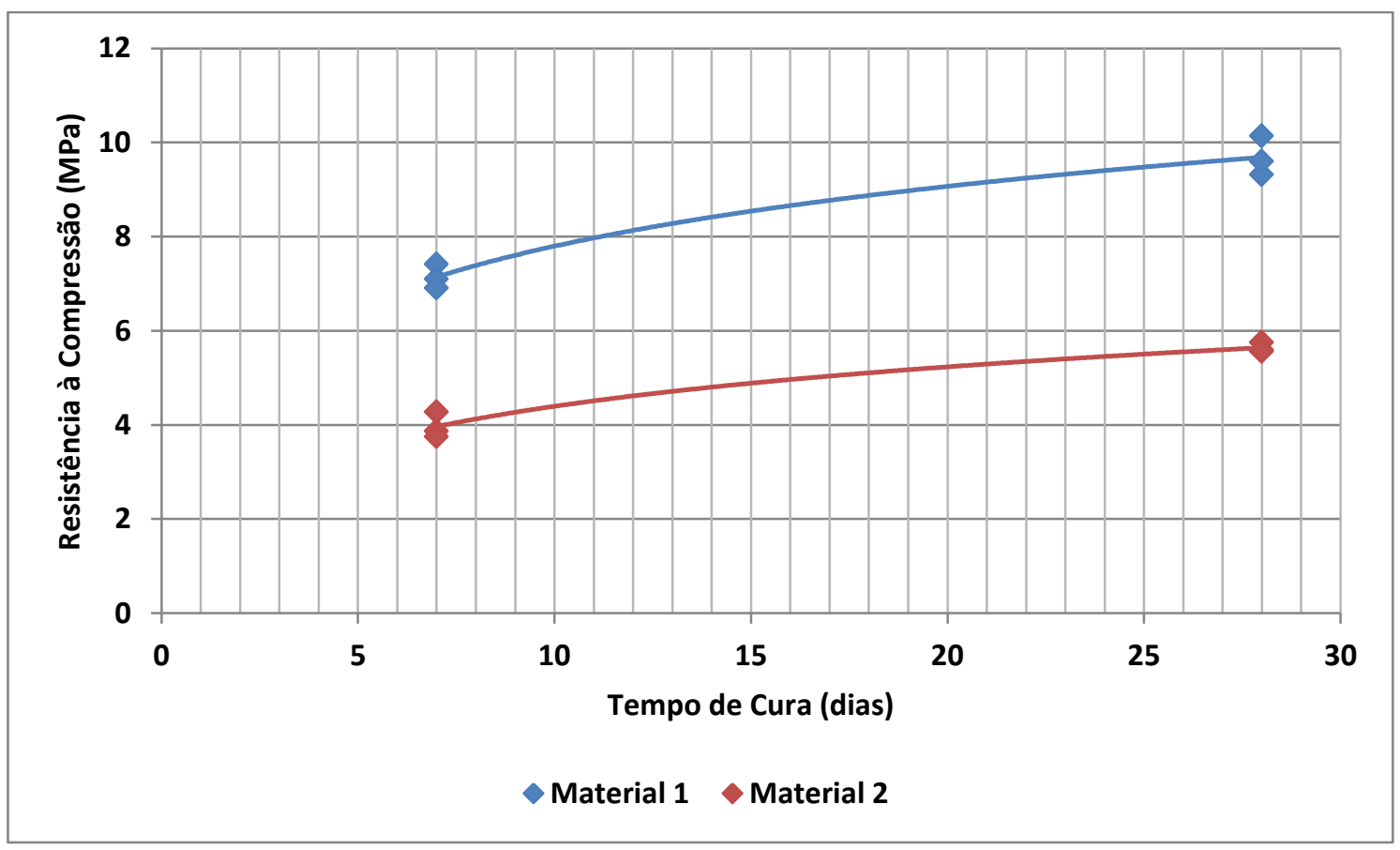

Figura 34 - Resultados de resistência à compressão - Variação de materiais

Assim como nos ensaios de resistência à tração, verificou-se a influência da cura na resistência à compressão dos dois materiais. O Material 1 manteve a superioridade nos resultados com tensões de ruptura da ordem de 9,5 MPa, enquanto o Material 2 apresentou tensões de ruptura da ordem de 5,5 MPa, em ambos os casos para 28 dias de cura.

De acordo com as especificações brasileiras, do DER/SP, os dois materiais apresentaram resistências à compressão superiores às mínimas estipuladas para CCR, BGTC e solo-cimento (5 MPa, $4 \mathrm{MPa}$ e $4 \mathrm{MPa}$, respectivamente).

Em seu estudo comparativo entre misturas de solo-cimento com um solo laterítico e outro não laterítico, Bechara et al. (2002) encontrou valores de resistência à compressão da ordem de 5,5 MPa em misturas com adição de 6\% de cimento. Valores esses compatíveis com os obtidos para o Material 2 reforçando a ideia de que a quantidade de material granular presente nessa mistura não é suficiente para 
garantir comportamento semelhante ao de misturas do tipo solo-brita-cimento, ou BGTC.

O Material 1, por sua vez, apresentou valores de resistência à compressão compatíveis, apesar de inferiores, aos obtidos para uma BGTC com 4\% de cimento estudada por Balbo (2002), indicando que, apesar de apresentar granulometria graúda, o Material 1 tem seus valores de resistência diminuídos pela presença de solo. Contudo, quando comparado às misturas solo-brita-cimento de material virgem com o mesmo teor de cimento (TOMEI, 2006), o Material 1 apresentou valores de resistência à compressão da ordem de 3 vezes superiores.

\subsubsection{Comparação entre Teores de Cimento}

Esse grupo de ensaios tem por objetivo testar a influência da variação do teor de cimento nas misturas. É esperado que o aumento da quantidade de cimento eleve os parâmetros de rigidez e de resistência das misturas cimentadas, contudo esse aumento varia em função de fatores como o tipo de solo presente na mistura e sua distribuição granulométrica.

Para a quantificação do ganho de rigidez e resistência resultantes do incremento do teor de cimento nas misturas recicladas, foram moldados corpos de prova em três grupos distintos, conforme apresentado na Tabela 7. Os corpos de prova foram submetidos aos ensaios de resistência à tração, resistência à compressão simples e módulo de resiliência para comparação dos resultados. Todos em três tempos de cura (3, 7 e 28 dias).

Tabela 7 - Características dos corpos de prova

\begin{tabular}{|c|c|c|c|}
\hline & Teor de Cimento & Teor de Umidade & $\begin{array}{c}\text { Energia de } \\
\text { Compactação }\end{array}$ \\
\hline Material 2 & $5 \%$ & Ótima $(6,5 \%)$ & Modificada \\
\hline Material 2 & $6 \%$ & Ótima $(6,5 \%)$ & Modificada \\
\hline Material 2 & $7 \%$ & Ótima $(7,5 \%)$ & Modificada \\
\hline
\end{tabular}




\section{a) Resistência à Tração}

Foram ensaiados três corpos de prova para cada tempo de cura de cada teor de cimento, totalizando vinte e sete corpos de prova. Os resultados (Figura 35) para os três períodos de cura testados mostraram o aumento dos valores de RT com o aumento dos teores de cimento. Nota-se que aos 3 dias de cura todos os corpos de prova apresentaram valores semelhantes de resistência à tração, não sendo possível diferenciar os teores de cimento dos três grupos e indicando que as reações de hidratação do cimento não haviam ocorrido de forma significativa.

Verifica-se que aos 28 dias de cura foi possível identificar os três patamares de resistência, referentes aos três teores de cimento avaliados. Pelos valores obtidos, verifica-se que enquanto o aumento de $5 \%$ para $6 \%$ de consumo de cimento resultou em um aumento médio de 0,2 $\mathrm{MPa}$ na tensão de ruptura das misturas, o aumento de $6 \%$ para $7 \%$ de consumo de cimento resultou em um aumento de 0,5 MPa.

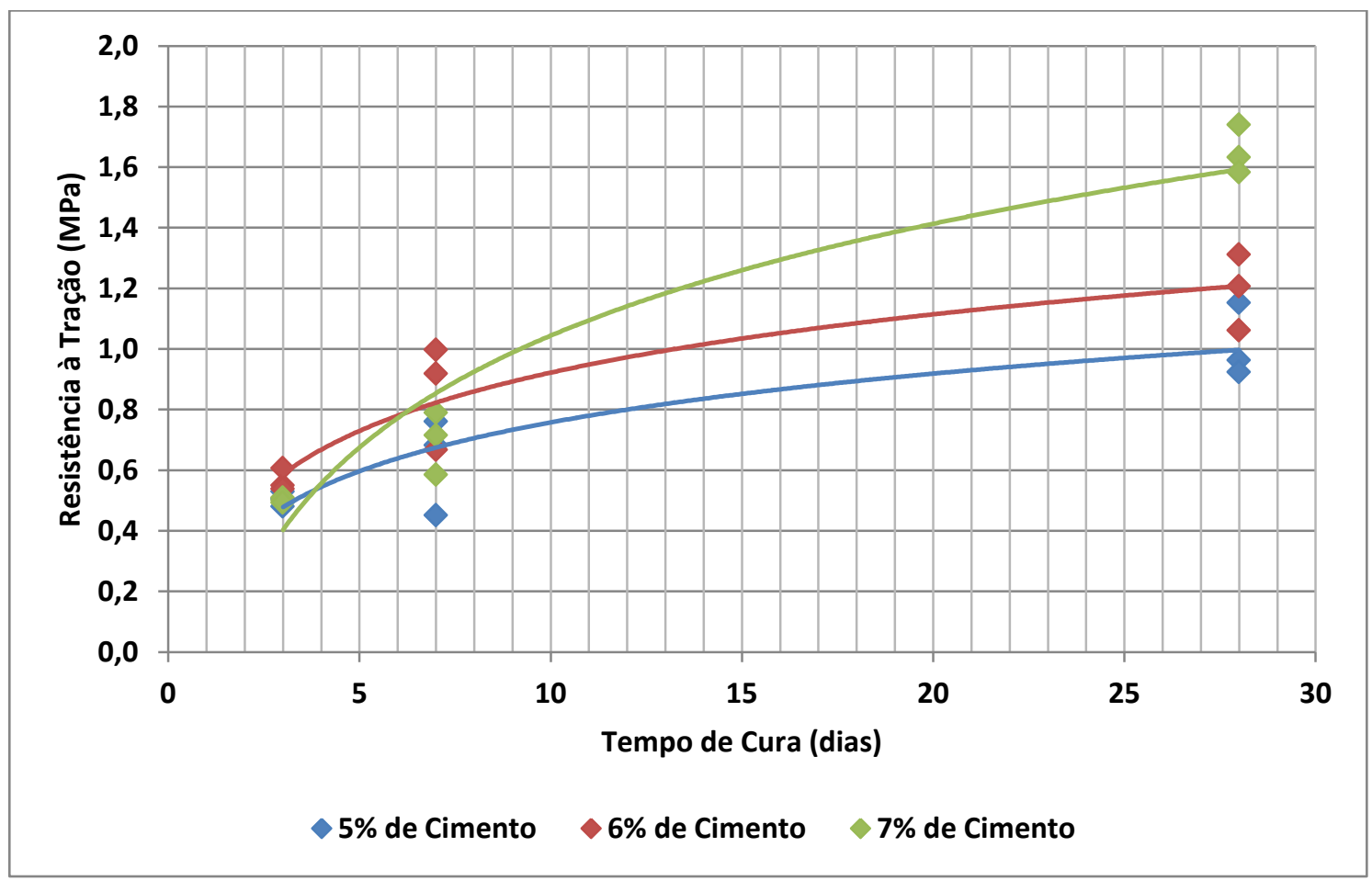

Figura 35 - Resultados de resistência à tração - Variação de teores de cimento 
Ao se testar estatisticamente as médias para os três teores de cimento e para os três tempos de cura verificou-se que para 3 e 7 dias de cura as médias de RT para os três teores de cimento podem ser consideradas iguais para um grau de $95 \%$ de confiabilidade no teste-t. Para os 28 dias de cura, são considerados iguais, pelo mesmo teste estatístico, as amostras com 5\% e $6 \%$ de cimento, sendo possível diferenciar apenas as amostras de $7 \%$ de cimento.

Em estudos relativos à tecnologia do concreto verifica-se que a relação água/cimento tem influência determinante nos valores de resistência (à tração e à compressão). Sabe-se que quanto maior essa relação, menores serão os valores de resistência apresentados pelo concreto, uma vez que quanto maior a quantidade de água presente na mistura maior será o volume de vazios da mesma (MEHTA; MONTEIRO, 2008). Dessa forma, foram calculadas as relações água/cimento das misturas testadas (Tabela 8). Verifica-se que além de ter o maior teor de cimento, a mistura com consumo de $7 \%$ de cimento apresenta a menor relação água/cimento, 0 que corrobora eu ganho mais acentuado de resistência.

Tabela 8 - Relação água/cimento das misturas ensaiadas

\begin{tabular}{|c|c|c|}
\hline Teor de Cimento (\%) & Teor de Umidade (\%) & Relação Água/cimento \\
\hline 5 & 6,5 & 1,30 \\
\hline 6 & 6,5 & 1,08 \\
\hline 7 & 7,5 & 1,07 \\
\hline
\end{tabular}

\section{b) Resistência à Compressão Simples}

Nesse grupo foram ensaiados, inicialmente, 2 corpos de prova para cada tempo de cura para cada teor de cimento, totalizando 12 corpos de prova. Os corpos de prova com $7 \%$ de cimento foram moldados em duas bateladas devido à inversão dos resultados verificada, resultando no dobro de corpos de prova para esse teor.

Os resultados obtidos nos ensaios de resistência à compressão simples, para 7 e 28 dias de cura e para os três teores de cimento, são apresentados no gráfico da Figura 36. Verifica-se que foi possível avaliar os efeitos da cura para os três teores de cimento. 


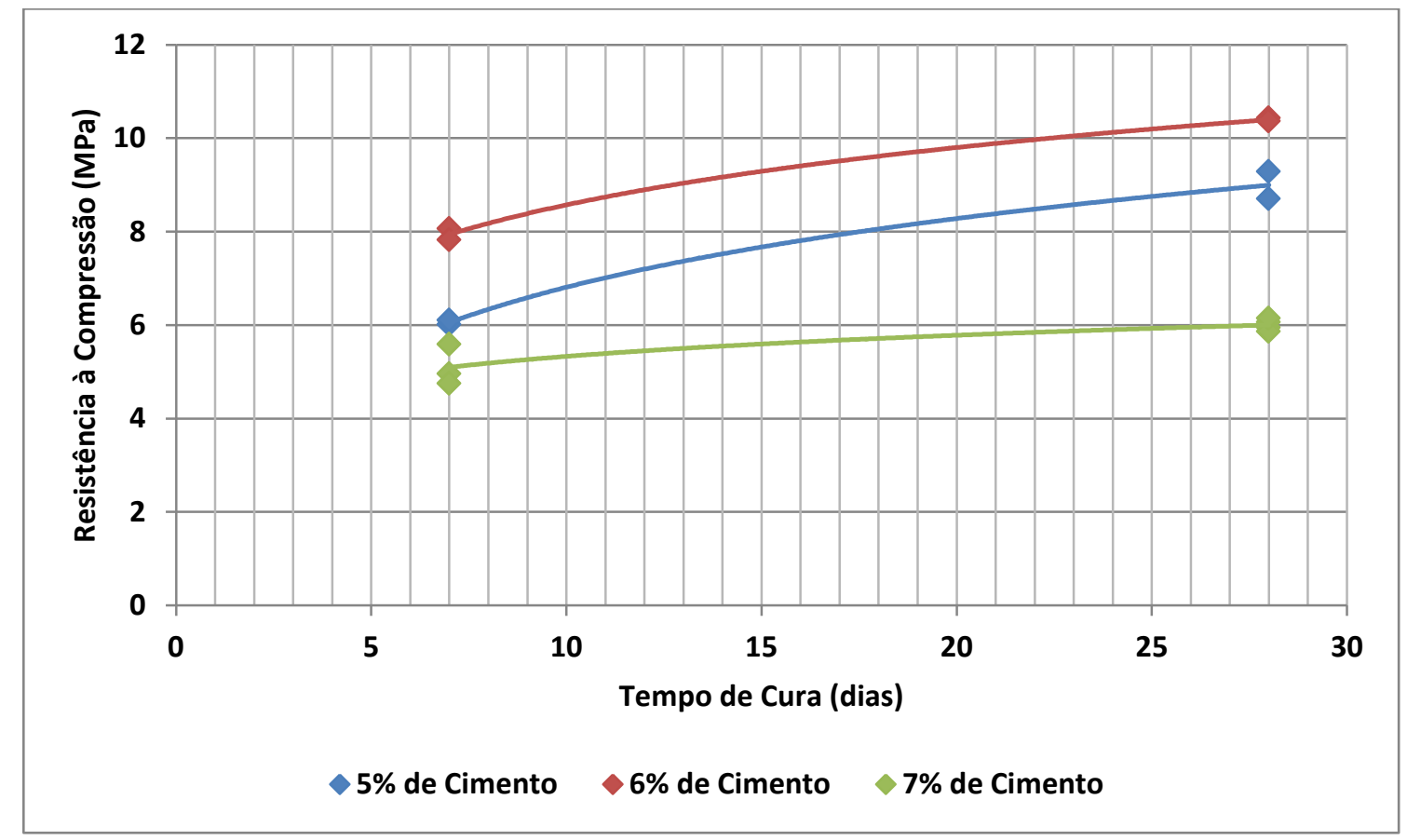

Figura 36 - Resultados de resistência à compressão - Variação de teores de cimento

Os ensaios das misturas com $5 \%$ e $6 \%$ de cimento apresentaram aumento de resistência com o aumento no teor de cimento, conforme esperado. Porém as misturas com $7 \%$ de cimento apresentaram valores significativamente inferiores aos demais, além de uma menor influência do tempo de cura.

A queda nos valores de RCS para $7 \%$ de cimento com relação aos demais percentuais avaliados pode estar relacionada à dosagem (definição da umidade ótima) dessas misturas, ou à problemas pontuais, ocorridos apenas nos corpos de prova de dimensões $10 \times 20 \mathrm{~cm}$ com teor de $7 \%$ de cimento.

Descartaram-se os problemas de dosagem, uma vez que os ensaios de resistência à tração não apresentaram a mesma queda. Dessa forma acredita-se que os problemas foram exclusivos desse grupo de corpos de prova. Um dos possíveis problemas apontados são as reações álcali-agregado, que ocorrem entre componentes do cimento e alguns tipos de material granular.

A reação álcali-agregado é um fenômeno que atinge compósitos que contém cimento, e se desenvolve quando há uma combinação de três fatores: álcalis do cimento, agregado reativo, ou potencialmente reativo, e a presença constante de 
umidade. Sua principal consequência é a redução brusca da resistência e a expansão dos materiais (MEHTA; MONTEIRO, 2008).

As evidências que apontam para essa causa são: (i) o fato das misturas com 7\% de cimento apresentarem maior concentração de cimento, o que facilita a ocorrência das reações químicas; (ii) o teor de umidade ser superior às demais misturas testadas, sendo esse um fator essencial para que as reações ocorram; e (iii) durante os ensaios observou-se uma pequena expansão dos corpos de prova, evidenciadas pela diferença entre o diâmetro do corpo de prova e o diâmetro da base da prensa.

Quando se descarta os resultados obtidos para os corpos de prova com $7 \%$ de cimento, verificam-se os efeitos do ganho de resistência causados pelo aumento do teor de cimento e a redução da relação água/cimento, conforme discutido na seção sobre resistência à tração nesse mesmo item.

\section{c) Módulo de Resiliência}

Conforme mencionado anteriormente, os ensaios de módulo de resiliência triaxial foram realizados nos mesmos corpos de prova que passaram em seguida aos ensaios de resistência à compressão simples, totalizando assim, 16 corpos de prova. Os resultados médios obtidos para uma tensão de confinamento de $0,1 \mathrm{MPa}$ são apresentados no gráfico da Figura 37. 


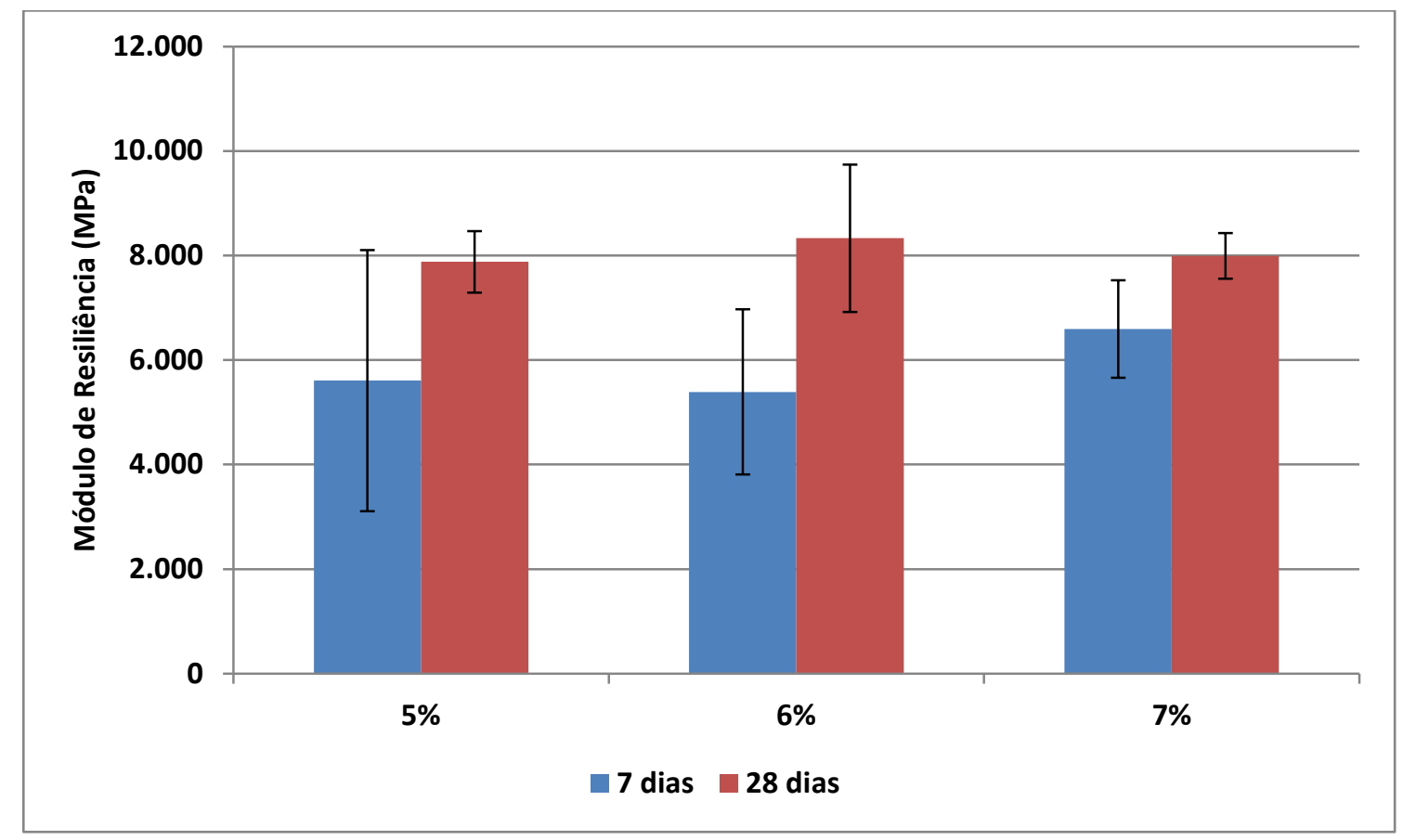

Figura 37 - Resultados de módulo de resiliência - Variação de teores de cimento

Como é possível se observar, os resultados obtidos apresentaram grande variabilidade, não sendo possível ranquear as misturas e nem os tempos de cura, devido aos elevados desvios padrão obtidos. Verifica-se, porém, que houve uma tendência de influência da cura na rigidez obtida para os três teores de cimento testados.

Para os três teores de cimento testados, o valor médio de módulo de resiliência obtido para os 28 dias de cura foi de $8000 \mathrm{MPa}$, condizente com o obtido por Balbo para um CCR com um consumo de cimento da ordem $3 \%$ em massa (BALBO, 2002). Quando comparado com misturas que contém solo em sua formulação, o material reciclado com cimento apresenta rigidez semelhante ao solo-cimento (10\% em massa) apresentado por Balbo (2002).

Ressalta-se que misturas que contém solo apresentam grande variabilidade na rigidez a depender do solo utilizado e da granulometria da mistura. Ceratti (1991) obteve variações de 13000 a 20000 MPa para um solo-cimento com teor de $6 \%$ de cimento e uma variação de 7500 e 11800 MPa para um solo-cimento distinto e com adição de $10 \%$ de cimento, em ambos os casos o solo obteve a mesma classificação MCT de não laterítico. 
O gráfico apresentado na Figura 37 não ilustra o efeito do confinamento nas misturas avaliadas. Dessa forma, os resultados completos do ensaio de módulo de resiliência, para cada teor de cimento e para os dois tempos de cura, são apresentados nos gráficos a seguir (Figura 38, Figura 39 e Figura 40).

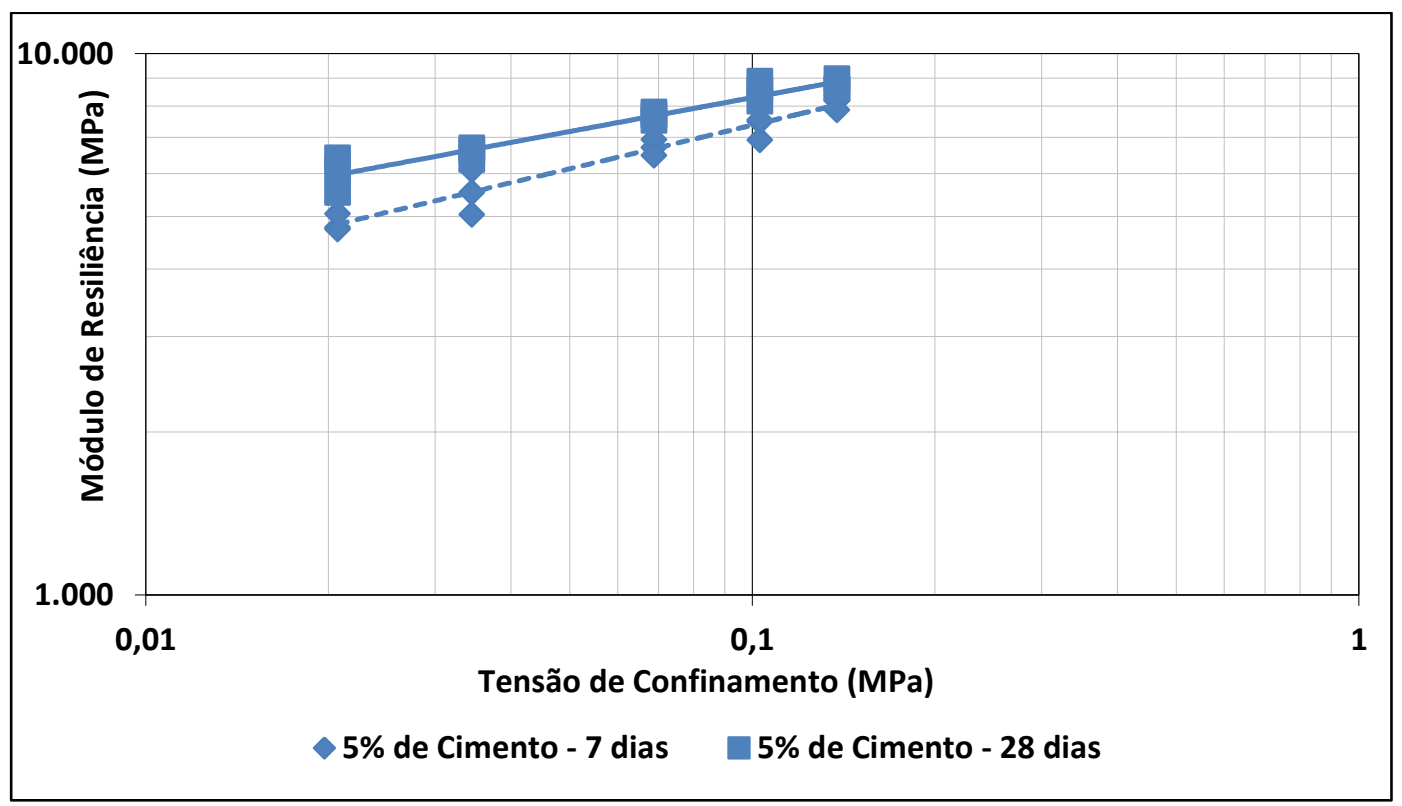

Figura 38 - Resultados de módulo de resiliência - 5\% de Cimento - Aos 7 e 28 dias de cura

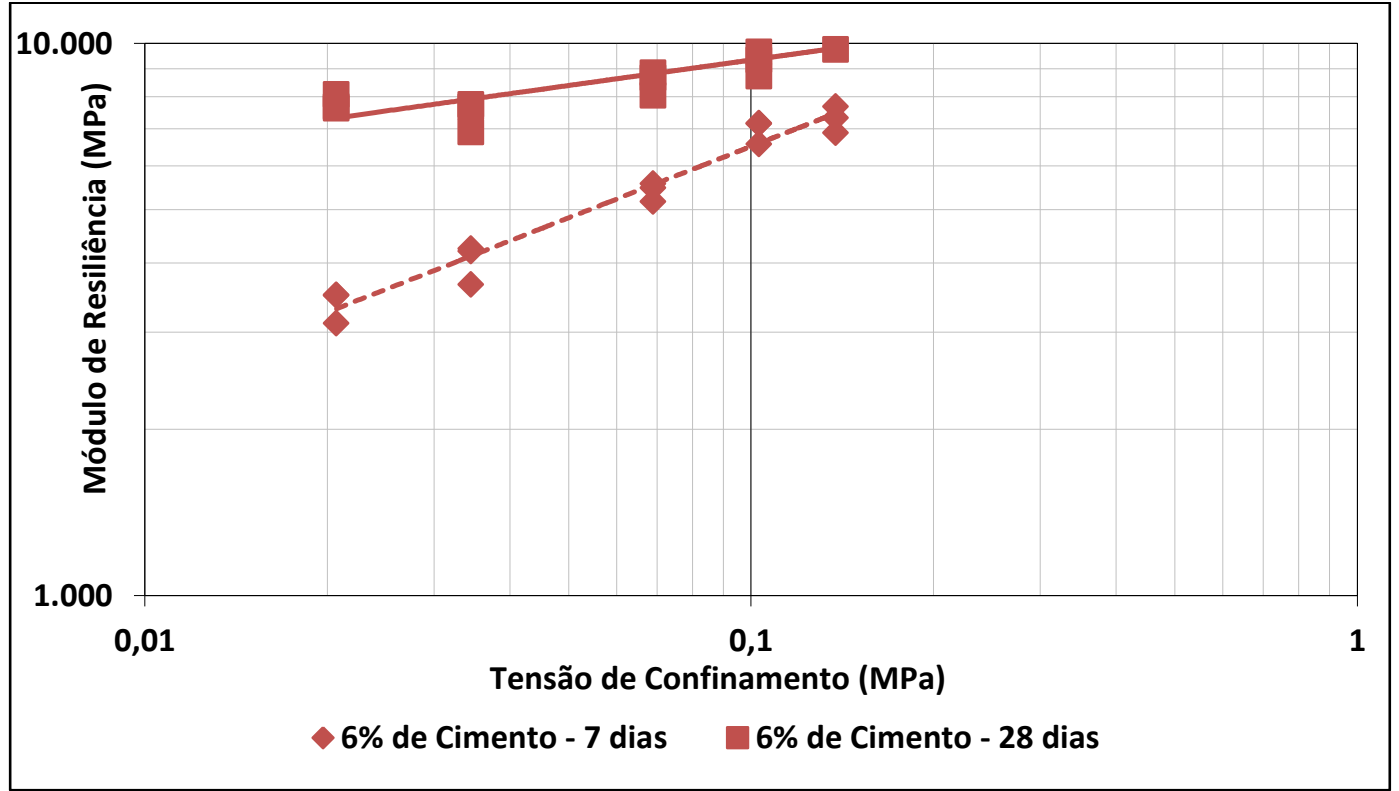

Figura 39 - Resultados de módulo de resiliência - $6 \%$ de Cimento - Aos 7 e 28 dias de cura 


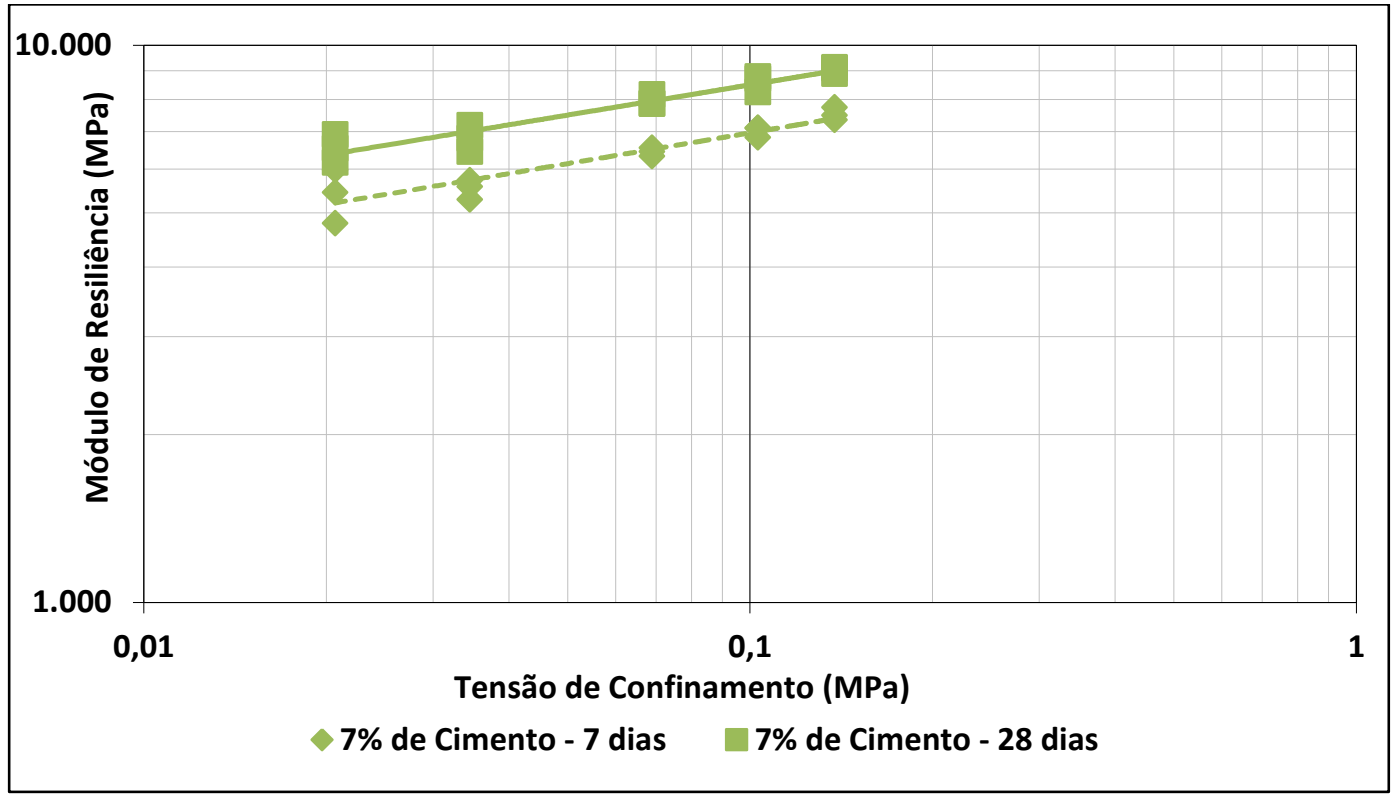

Figura 40 - Resultados de módulo de resiliência - 7\% de Cimento - Aos 7 e 28 dias de cura

Para os três casos apresentados foi possível se verificar a influência da tensão de confinamento no valor de módulo de resiliência dos materiais, sendo que essa influência diminui aos 28 dias, quando o material já apresentou o enrijecimento devido à hidratação do cimento. O gráfico da Figura 41 representa uma curva de cada mistura, todas ensaiadas aos 28 dias de cura para melhor visualização das diferenças. Esse gráfico ilustra também a menor influência da tensão de confinamento para as três misturas ao fim do período de cura, indicando que o material passou a ter um comportamento de material coesivo e não granular, como ocorre em suas primeiras idades.

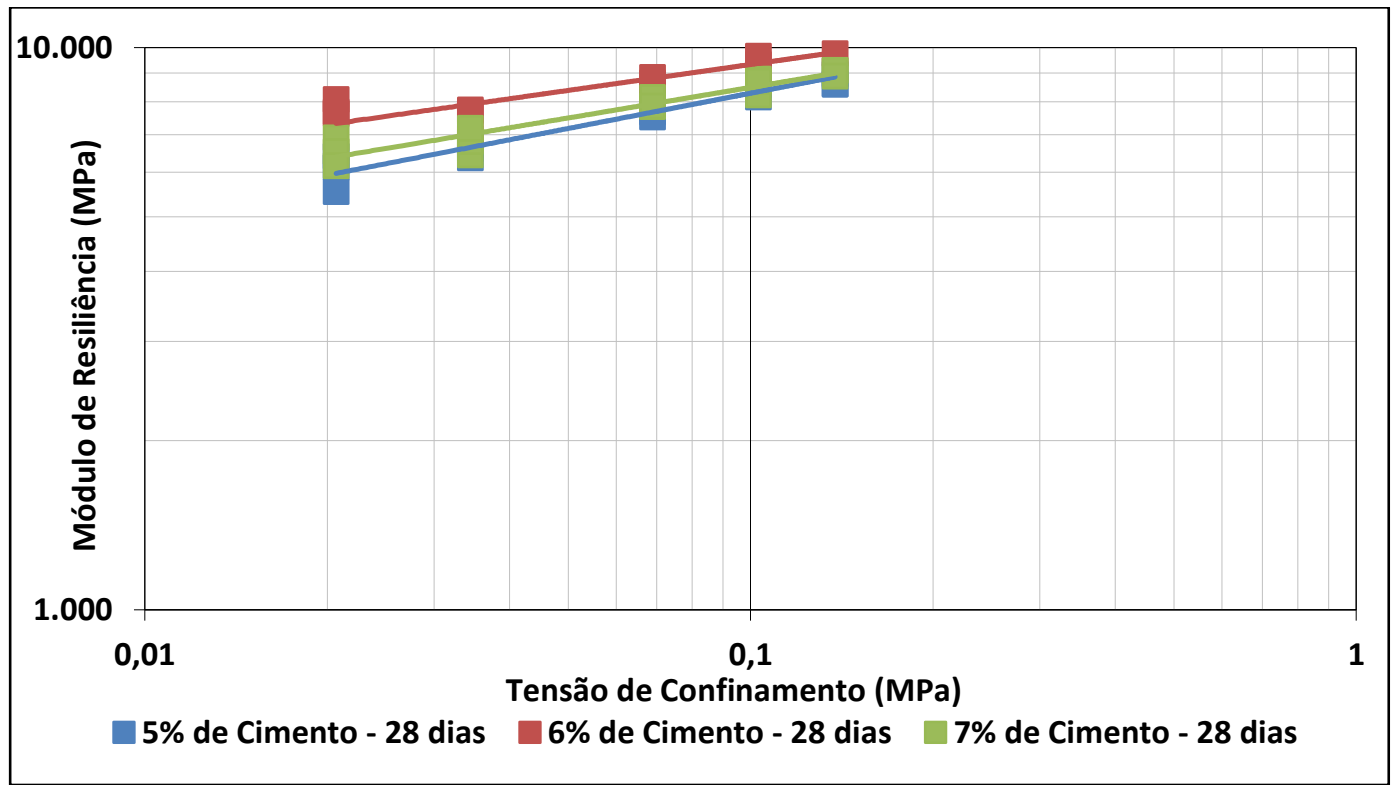

Figura 41 - Resultados de módulo de resiliência - Aos 28 dias de cura 


\subsubsection{Comparação entre Energias de Compactação}

As normas brasileiras definem a energia intermediária de compactação para misturas de solo-brita-cimento ou solo-cimento. Contudo, é sabido que na Europa e nos Estados Unidos todo o controle da compactação do campo é feito com base na energia modificada (BALBO, 2002). Somado a isso, sabe-se que a normatização internacional não prevê uma energia intermediária de compactação, sendo utilizadas apenas a energia normal, ou a modificada.

A aplicação da energia modificada deve garantir uma compactação mais eficiente e um teor ótimo de umidade menor com relação a energias de compactação menos severas. A fim de se identificar e quantificar os benefícios da maior energia de compactação, o Material 2 reciclado com 5\% de cimento foi testado em termos de resistência à tração, e resistência à compressão simples para as energias intermediária e modificada. As características das amostras testadas são apresentadas na Tabela 9.

Tabela 9 - Características dos corpos de prova

\begin{tabular}{|c|c|c|}
\hline Teor de Cimento & Teor de Umidade & Energia de Compactação \\
\hline $5 \%$ & Ótima $(7,5 \%)$ & Intermediária \\
\hline $5 \%$ & Ótima $(6,5 \%)$ & Modificada \\
\hline
\end{tabular}

\section{a) Resistência à Tração}

Nesse grupo foram ensaiados três corpos de prova para cada tempo de cura, em cada energia de compactação, num total de dezoito amostras. A diferença observada para as duas energias de compactação ficaram dentro da variabilidade do próprio ensaio (Figura 42).

Ao se testar os resultados dos três tempos de cura pelo do teste-t, com grau de confiança de $95 \%$ não foi possível se diferenciar as médias para diferentes energias de compactação. Acredita-se que não foi possível verificar o efeito da energia da compactação nesse ensaio devido ao plano de aplicação de carga nesse ensaio ser oposto ao plano de compactação do corpo de prova. 


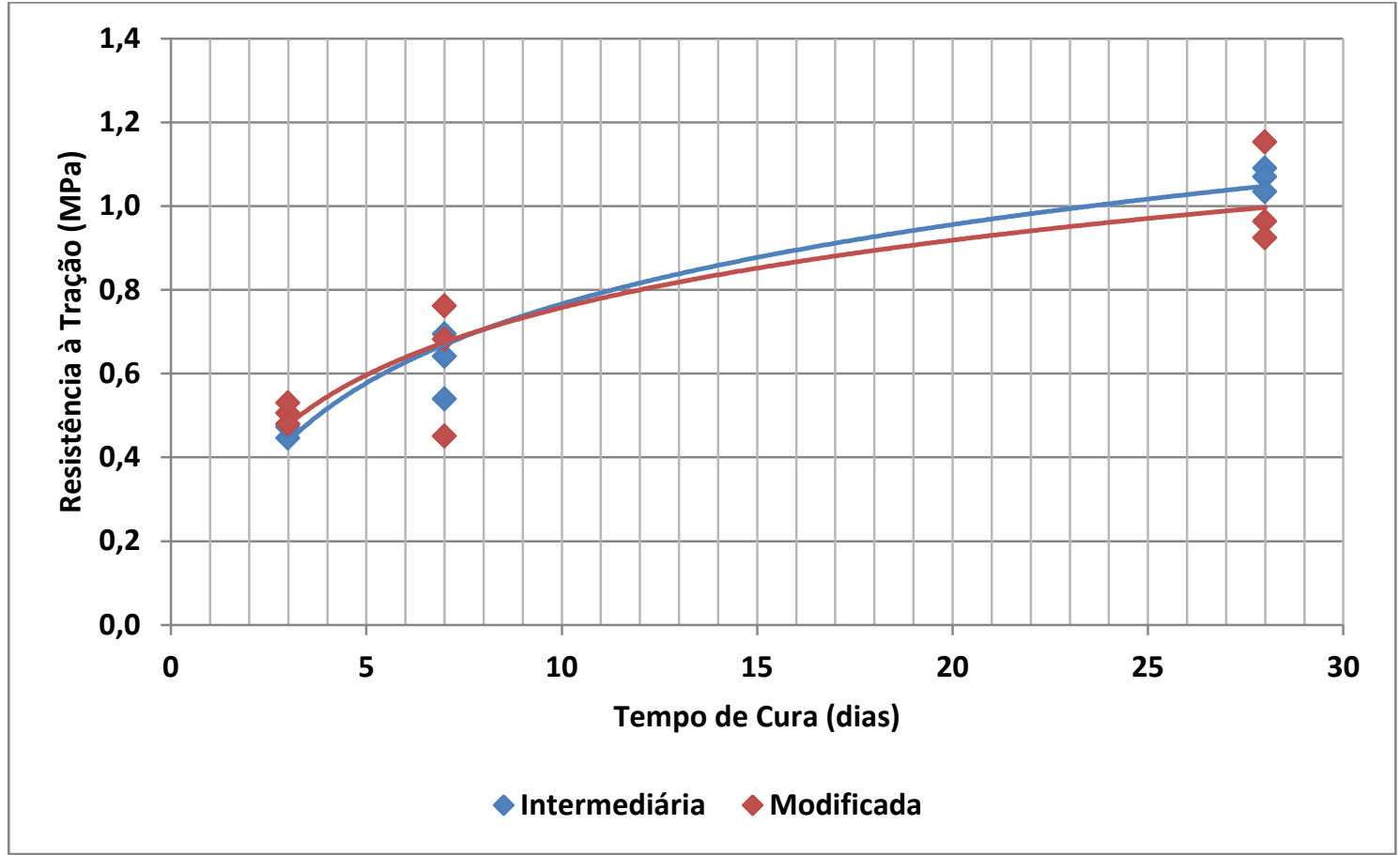

Figura 42 - Resultados de resistência à tração - Variação da energia de compactação

\section{b) Resistência à Compressão}

Através dos ensaios de resistência à compressão simples, apresentados na Figura 43, foi possível verificar a influência da variação na compactação das amostras. Os corpos de prova compactados na energia modificada apresentaram valores de resistência superiores desde os 7 dias de cura. 


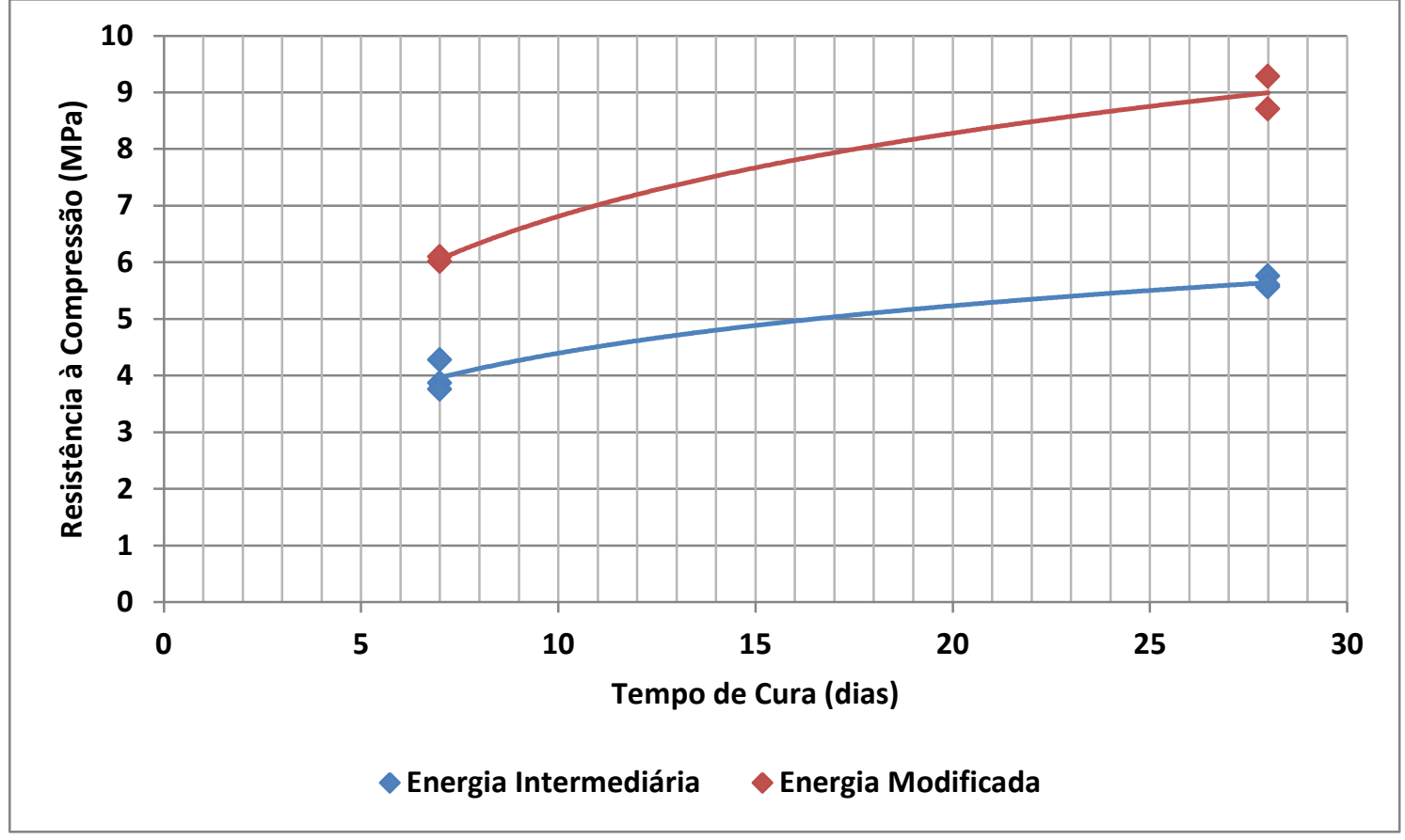

Figura 43 - Resultados de resistência à compressão - Variação da energia de compactação

Atribuiu-se o fato da energia de compactação não ter influenciado nos ensaios de resistência à tração a coesão que o cimento proporciona à mistura no plano de solicitação do ensaio (tração indireta). Em contrapartida, o ensaio à compressão causa o cisalhamento entre as partículas que apresenta mais resistência a esse esforço quando as amostras estão mais compactadas, havendo maior contato entre os grãos. Outra causa que pode ter levado a essa diferença no efeito da compactação entre a resistência da amostra a tração e a compressão, seria a direção do plano de compactação, com relação ao plano de ensaio, conforme ilustrado na Figura 44 abaixo. 


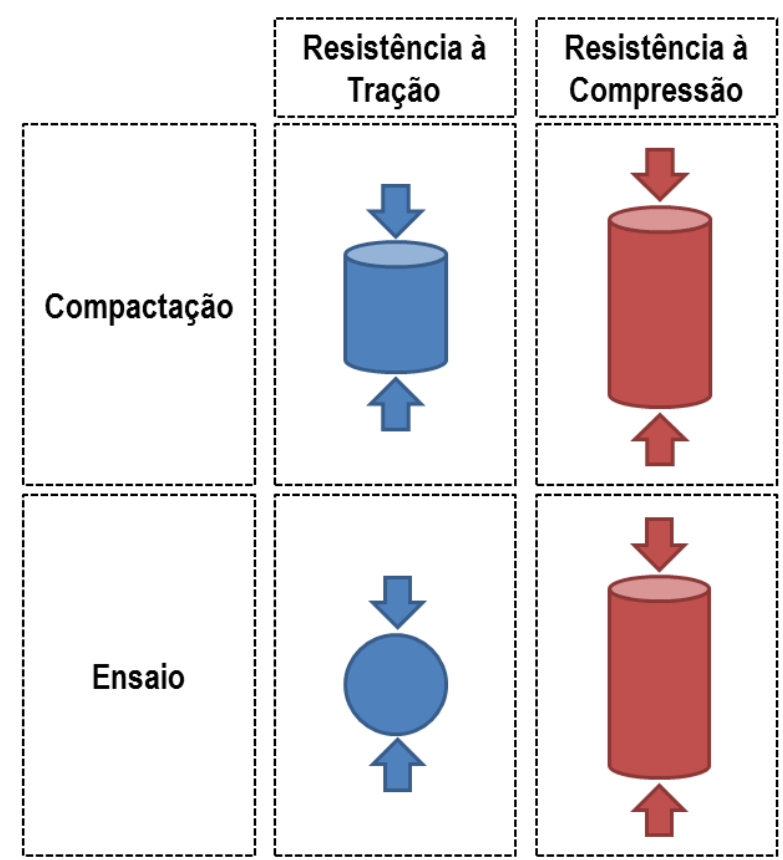

Figura 44 - llustração do plano de compactação e do plano de ensaio no RT e na RCS

\subsubsection{Avaliação do Tempo de Cura}

As propriedades mecânicas de misturas que contém cimento variam em função da cura do material por causa do processo de hidratação do cimento. Nas misturas estudadas, essa variação é influenciada pelas características do solo e granulometria do material, sendo seu estudo importante para a compreensão do comportamento dos materiais ao longo do tempo.

Obras rodoviárias buscam o menor tempo possível de abertura para o tráfego, tornando o conhecimento dos parâmetros de resistência do material nas primeiras idades extremamente importante. Foram realizados ensaios de resistência à tração em corpos de prova com seis idades de cura distintas, variando-se de 1 dia de cura até 28 dias, nas condições de moldagem apresentadas na Tabela 10.

Tabela 10 - Características dos corpos de prova

\begin{tabular}{|c|c|c|c|}
\hline & Teor de Cimento & Teor de Umidade & Energia de Compactação \\
\hline Material 2 & $5 \%$ & Ótima $(7,5 \%)$ & Intermediária \\
\hline
\end{tabular}


Através dos ensaios foi possível identificar que o crescimento da resistência à tração com o tempo não ocorre de maneira linear. Verifica-se que após 14 dias de cura o acréscimo de resistência é muito inferior ao que ocorre até os 14 dias indicando que as reações de hidratação do cimento são muito mais intensas nesse período e vão diminuindo gradativamente até estabilizarem, o que ocorre, teoricamente, aos 28 dias (Figura 45).

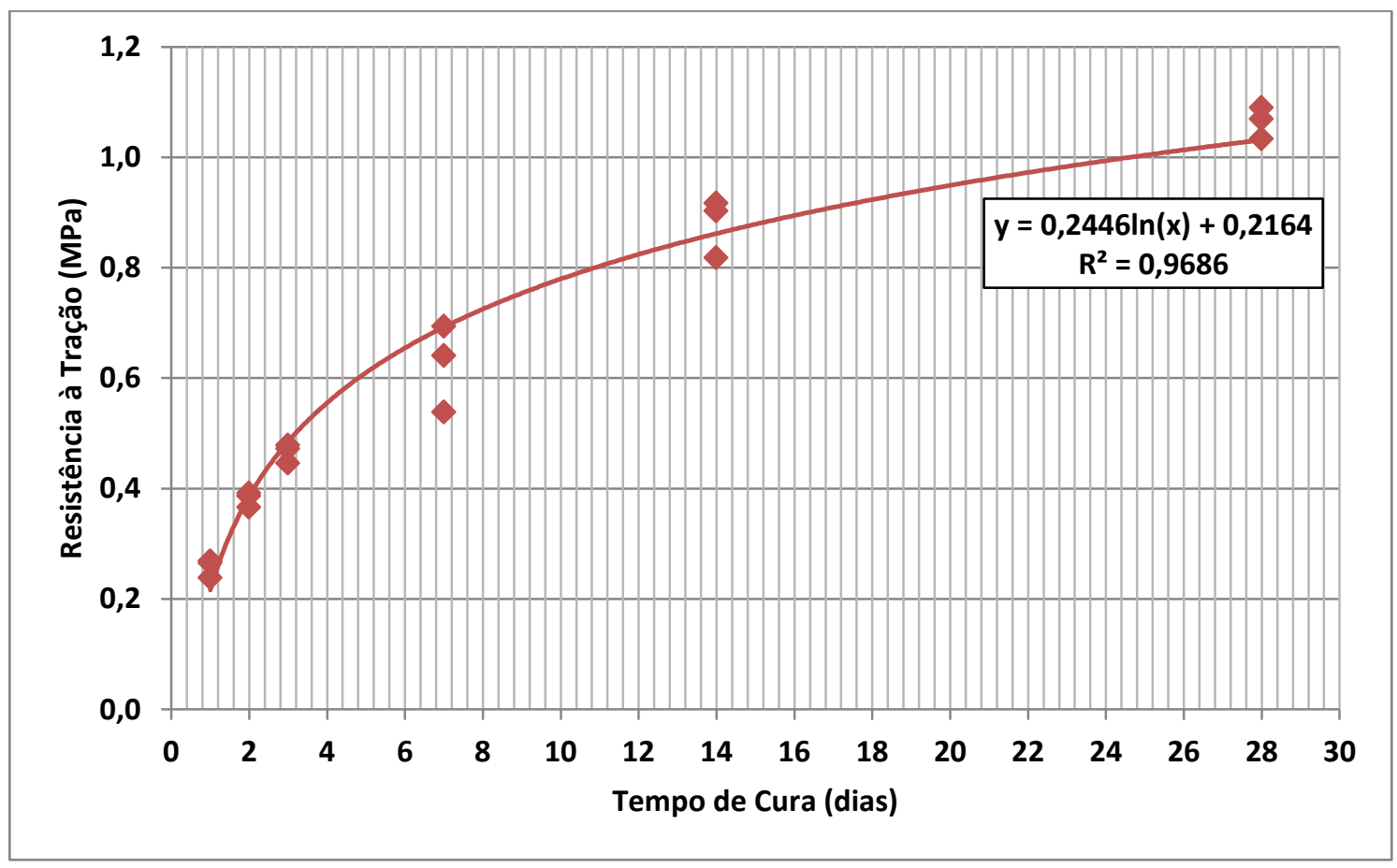

Figura 45 - Avaliação da cura do material cimentado

A evolução na cura de materiais cimentados em pavimentação geralmente é avaliada através de modelos lineares com menos pontos de observação. Contudo estudos mostram que o ganho de resistência não ocorre linearmente. Aio et al. (2004) testou quatro misturas de solo-cimento para seis tempos de cura que variavam de 3 a 120 dias. Verificou a tendência não linear de ganho de resistência e a influência da relação água/cimento no formato dessa curva.

O IBRACON (Instituto Brasileiro de Concreto) define tempos mínimos de cura do concreto com base nessa relação água/cimento. Quanto maior a relação menor será a velocidade do ganho de resistência (IBRACON, 2005), sendo que ao se dobrar a relação a/c o tempo mínimo de cura para o concreto passa de 3 para 10 dias. Para 
uma mistura solo-cimento com relação a/c de 2, Morais (2002) verificou ganhos de resistência até os 240 dias de cura.

A velocidade do ganho de resistência nas misturas cimentadas também é dependente do cimento utilizado. Cada tipo de cimento atende a objetivos específicos e tem o tempo de hidratação distinto (IBRACON, 2005). Assim, verificase que a forma da curva da cura do material é específica para cada mistura e dependente da granulometria, dosagem e do cimento utilizado. 


\section{TRECHO EXPERIMENTAL}

Dentro do escopo da pesquisa houve também a construção de um trecho experimental para avaliação do desempenho da mistura reciclada com cimento em campo. O trecho experimental está localizado entre os quilômetros 641,5 e 642,3 da Rodovia Fernão Dias (Figura 46), trecho que liga São Paulo a Belo Horizonte, sentido São Paulo. A rodovia foi construída na década de 1950, tendo passado por obras de duplicação em meados da década de 1990, onde seu traçado original procurou ser mantido.

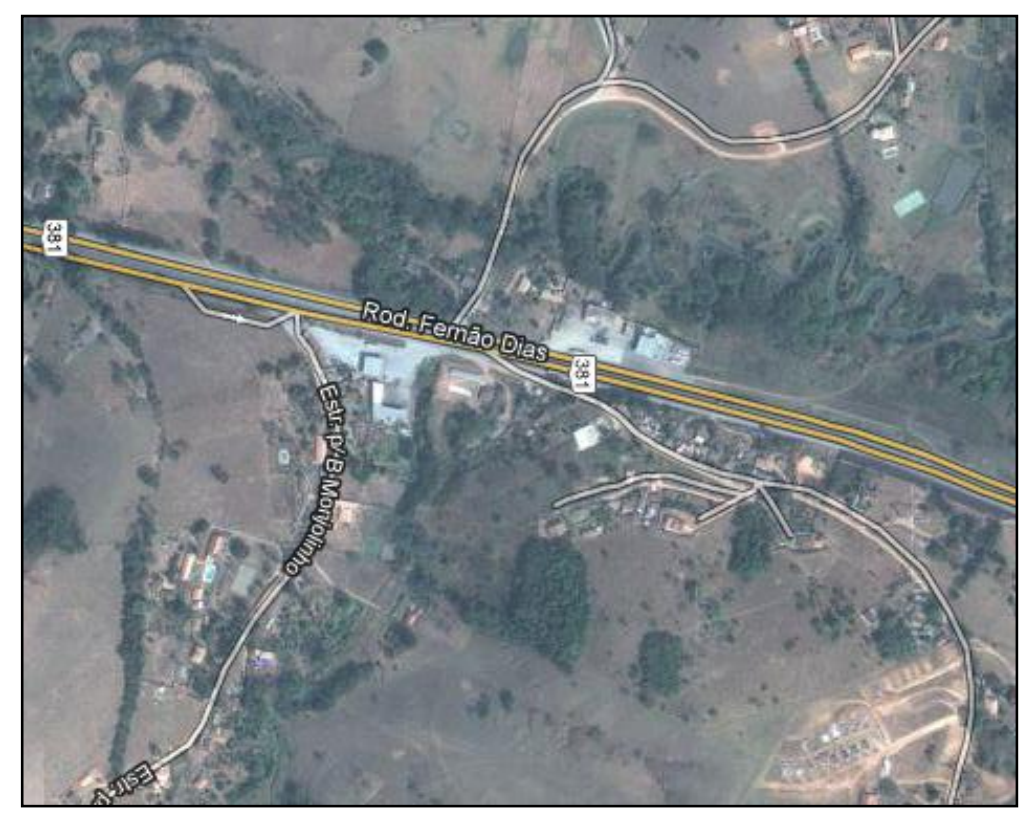

Figura 46 - Localização do trecho experimental

O pavimento passou a apresentar problemas estruturais, consequentes das condições de sua base e seu subleito. Muitos problemas de subleito são advindos do período de sua construção devido a deficiências e variações nos materiais disponíveis para compor as camadas de base, ao longo de toda a extensão da rodovia. Foram realizadas algumas sondagens antes da execução do trecho experimental, onde se observou uma série de variações no tipo do material, além das espessuras encontradas nas camadas de base ao longo da rodovia. Os materiais encontrados são apresentados na Tabela 11. 
Tabela 11 - Materiais encontrados na rodovia Fernão Dias

\begin{tabular}{|c|c|c|}
\hline $\begin{array}{c}\text { Reforço do } \\
\text { Subleito/Subleito }\end{array}$ & Sub-base & Base \\
\hline Escória & Escória & Canga de Minério + Escória \\
\hline Argila & Escória + Argila & Canga de Minério \\
\hline Canga de Minério & Saibro & Canga de Minério + Cal \\
\hline Rachão & Canga de Minério & Brita + Solos \\
\hline Quartzo & Quartzo & Brita Graduada \\
\hline & Saibro + Brita & \\
\hline & Rachão & \\
\hline & Brita + Solos & \\
& $\begin{array}{c}\text { Canga de Minério + } \\
\text { Escória }\end{array}$ \\
\hline
\end{tabular}

A região de escolha do trecho experimental está situada onde o revestimento é de concreto asfáltico, a base de solo brita e o reforço de subleito em canga de minério, sendo esses materiais os utilizados nos processos de reciclagem e reconstrução do pavimento. A estrutura antiga do pavimento é apresentada na Figura 47.

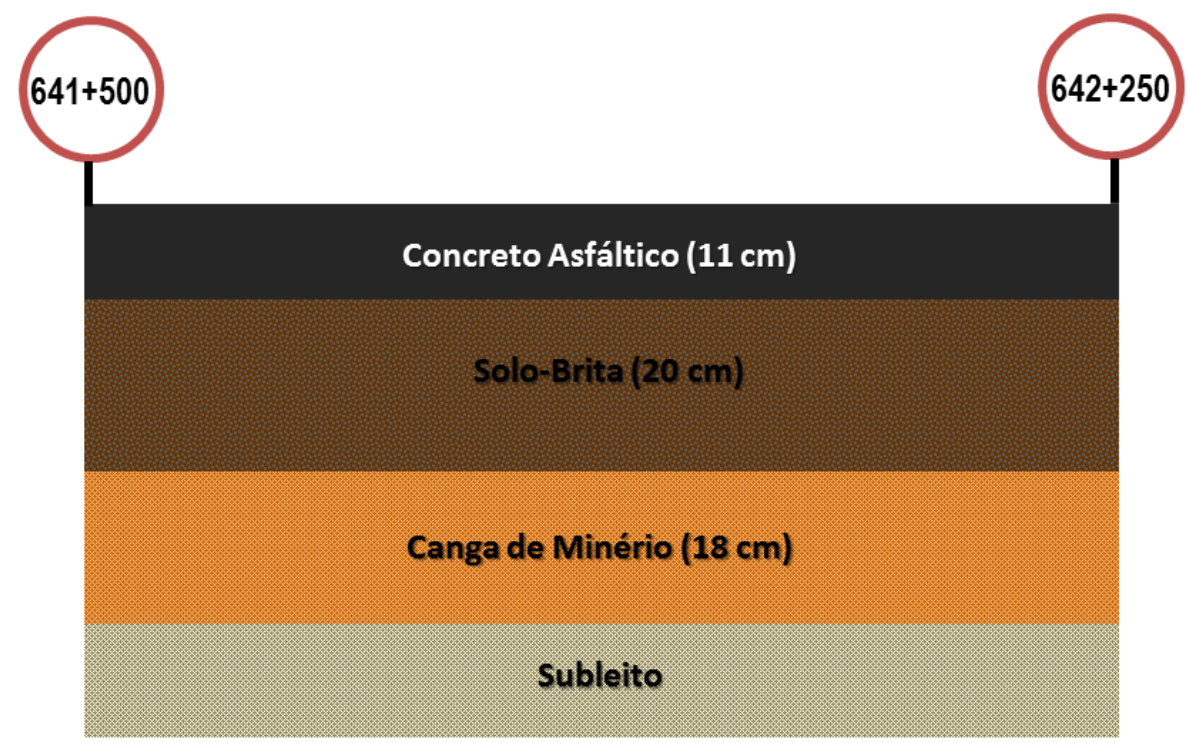

Figura 47 - Estrutura do pavimento deteriorado

O projeto para a reconstrução da rodovia, no segmento onde se encontra o trecho experimental, prevê um pavimento semirrígido, com sub-base de material reciclado cimentado, base de mistura reciclada com emulsão e capa de mistura com concreto asfáltico novo. 
A fim de se avaliar a influência da camada cimentada na estrutura do pavimento, o projeto contemplou a variação da espessura dessa camada, sendo o trecho composto de três segmentos de 250 metros de comprimento. A variação nas espessuras da camada reciclada com cimento resulta na variação de materiais na composição da mistura, visto que o segmento com $20 \mathrm{~cm}$ de espessura de camada de material reciclado com cimento não contém canga de minério, diferentemente dos demais segmentos. A estrutura final do trecho experimental é apresentada na Figura 48.

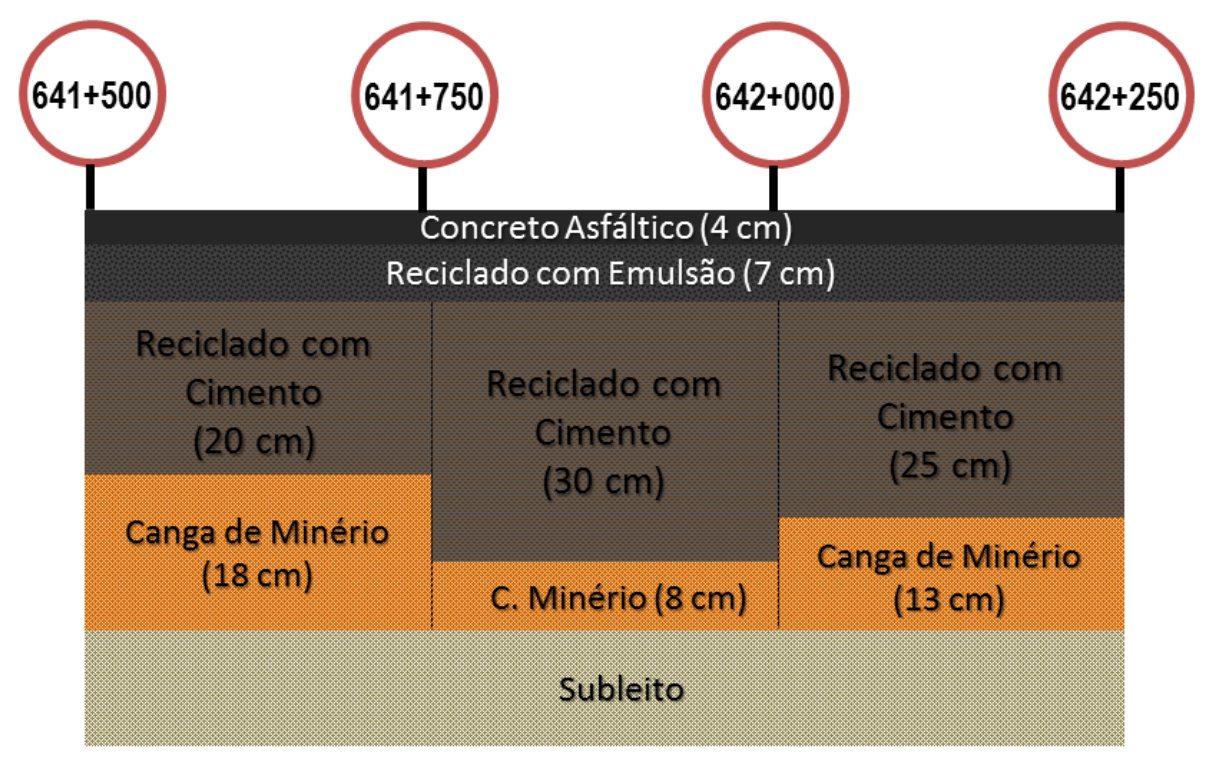

Figura 48 - Variação estrutural no trecho experimental

Dessa forma, o pavimento restaurado contempla duas camadas compostas por material reciclado. A camada denominada reciclado com emulsão é composta pelo material resultante da fresagem da camada de rolamento (RAP) com adição de emulsão asfáltica e $1 \%$ de cimento. A camada denominada reciclado com cimento é composta da antiga base de solo-brita com adição de $5 \%$ de cimento.

A variação de espessuras da camada cimentada proposta em projeto tem o objetivo de analisar sua influência no comportamento estrutural do pavimento em termos de redução das deflexões máximas, que são consequência do estado de tensões, rigidez e integridade de cada camada. 
O material que compõe a mistura reciclada com cimento no trecho de estudo é a mistura de solo-brita (Material 1) abordada no Capitulo 4, salvo variações de granulometria decorrentes do processo de reciclagem. Não existe um processo de dosagem consagrado para as misturas cimentadas. Os teores cimento são geralmente definidos por análise mecanicista, de modo que se obtenham valores de resistência à tração e compressão suficientes para o projeto estrutural do pavimento. Dessa maneira, foi estabelecido um consumo de cimento de $5 \%$ em massa da mistura para a construção do trecho experimental.

A variação de espessuras da camada cimentada proposta em projeto tem o objetivo de analisar suas influências no comportamento estrutural do pavimento em termos de redução das deflexões máximas, que são consequência do estado de tensões, rigidez e integridade de cada camada.

O material que compõe a mistura reciclada com cimento no trecho de estudo é a mistura de solo-brita citada anteriormente. Não existe um processo de dosagem para as misturas cimentadas, os teores cimento são definidos por análise mecanicista de modo que se obtenham valores de resistência à tração e compressão suficientes para o projeto estrutural do pavimento, dessa maneira foi estabelecido um consumo de cimento de 5\% em massa da mistura para a construção do trecho experimental.

\subsection{CONSTRUÇÃO DO TRECHO EXPERIMENTAL}

O processo de construção do trecho experimental se estendeu por um período de sete dias no mês de agosto de 2011. A restauração iniciou-se com a extração da camada de revestimento em concreto asfáltico deteriorado na espessura total de $11 \mathrm{~cm}$ da camada - Figura 49 e Figura 50. A fresagem, realizada a frio, fraturou 0 revestimento existente, reduzindo em partes menores que foram posteriormente tratadas de modo a compor a camada reciclada com emulsão. 


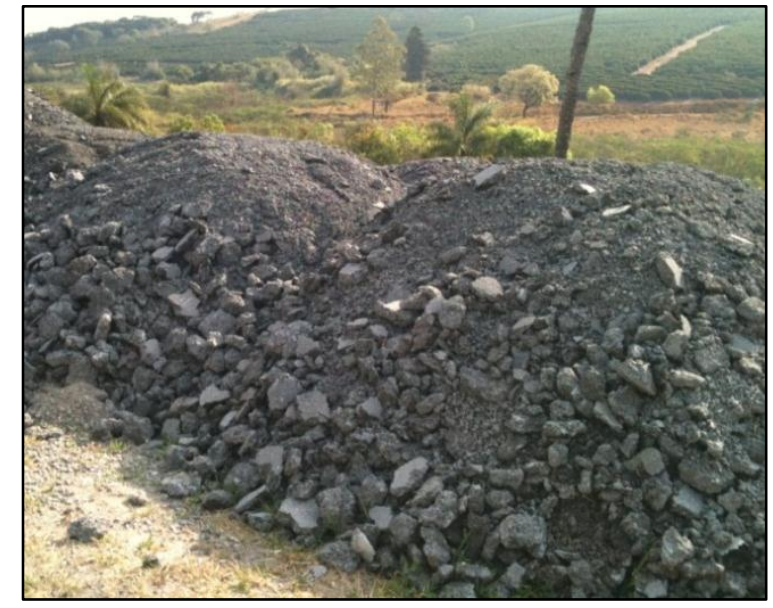

Figura 49 - Material proveniente da fresagem (RAP)

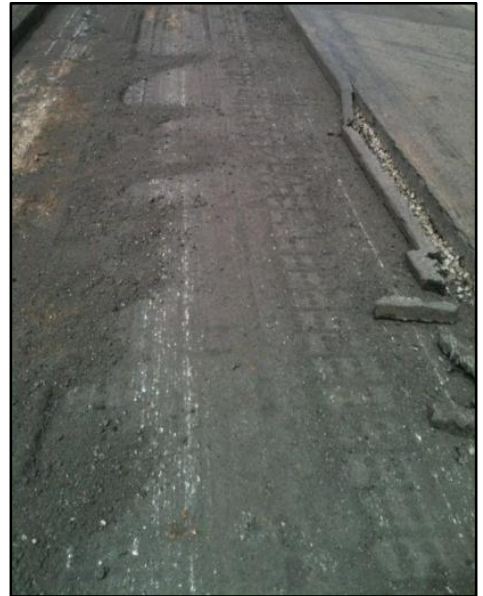

Figura 50 - Trecho após fresagem

Após a retirada do material fresado, denominado RAP - Reclaimed Asphalt Pavement, a camada de base existente em solo-brita ficou exposta. Este material recebeu estabilização química com cimento para a constituição da camada reciclada de sub-base, denomida nesse trabalho de reciclagem com cimento.

Para a execução da camanda reciclada com cimento, o cimento foi distribuído com auxílio de caminhão-cilo, no teor de $5 \%$ em massa definido em projeto, conforme apresentado na

Figura 51. É possível realizar a distribuição do cimento por um processo manual de espalhamento de sacos de cimentos, na proporção necessária, contudo o processo com o apoio do caminhão apresenta maior precisão no teor de cimento e garante espalhamento adequado por toda a largura da pista - Figura 52.

Além disso, como o projeto de restauração contempla variação da espessura da camada cimentada a quantidade de cimento que deve ser distribuída ao longo da pista é variável, sendo possível fazer esse controle quando se utiliza o caminhãocilo. 


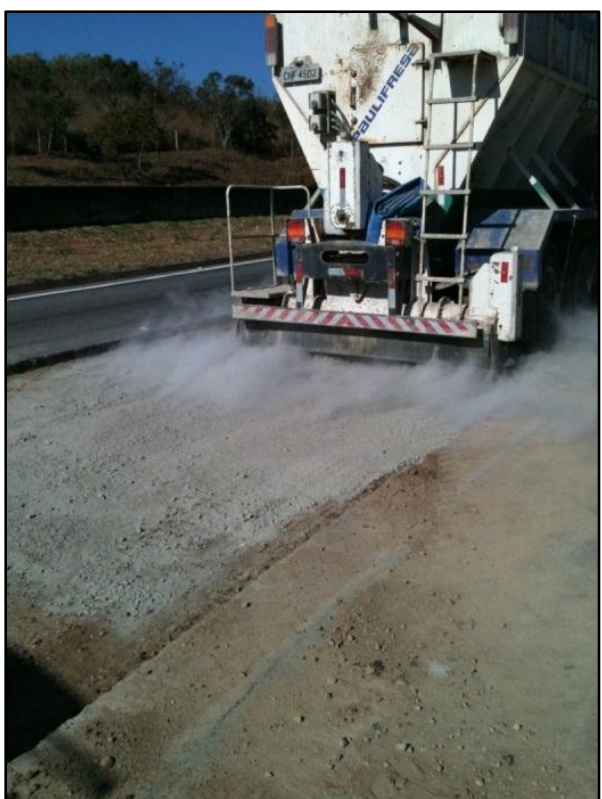

Figura 51 - Distribuição do cimento no trecho experimental

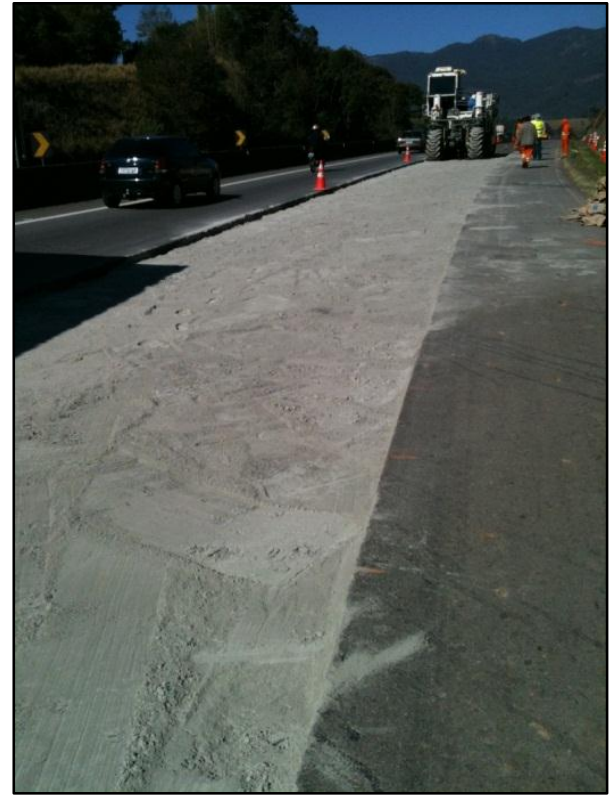

Figura 52 - Trecho após a distribuição do cimento

A adição de água foi realizada pelo equipamento reciclador. O caminhão tanque, é acoplado por meio de mangueira ao equipamento reciclador, de modo que o próprio equipamento controla eletronicamente o teor de água lançado na mistura - Figura 53 e Figura 54. O caminhão não interfere na velocidade de reciclagem, sendo empurrado pelo reciclador por meio de ligação por mangote.

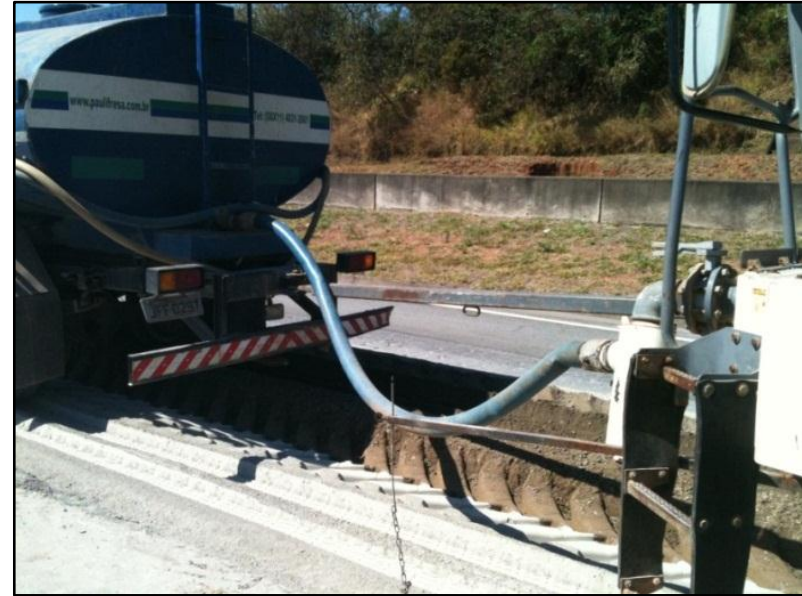

Figura 53 - Distribuição da água pelo equipamento reciclador

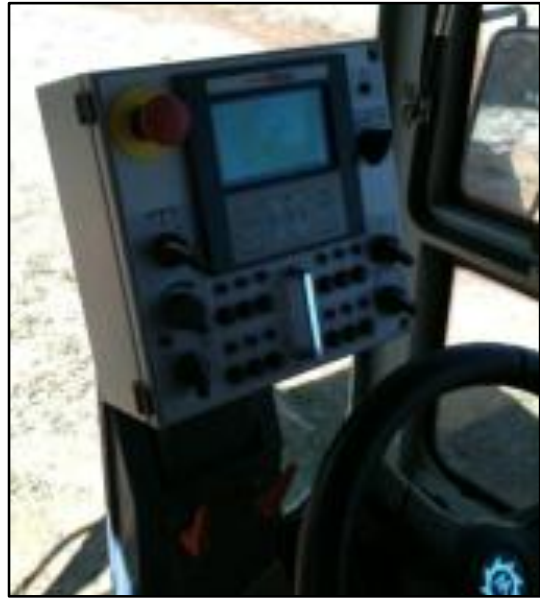

Figura 54 - Painel de controle do equipamento reciclador

O equipamento reciclador é controlado eletronicamente com a definição de espessura necessária, e garantindo por um processo contínuo de rotação do cilindro 
misturador, de homogenização do material existente de base (solo-brita), do cimento e da água (Figura 55).

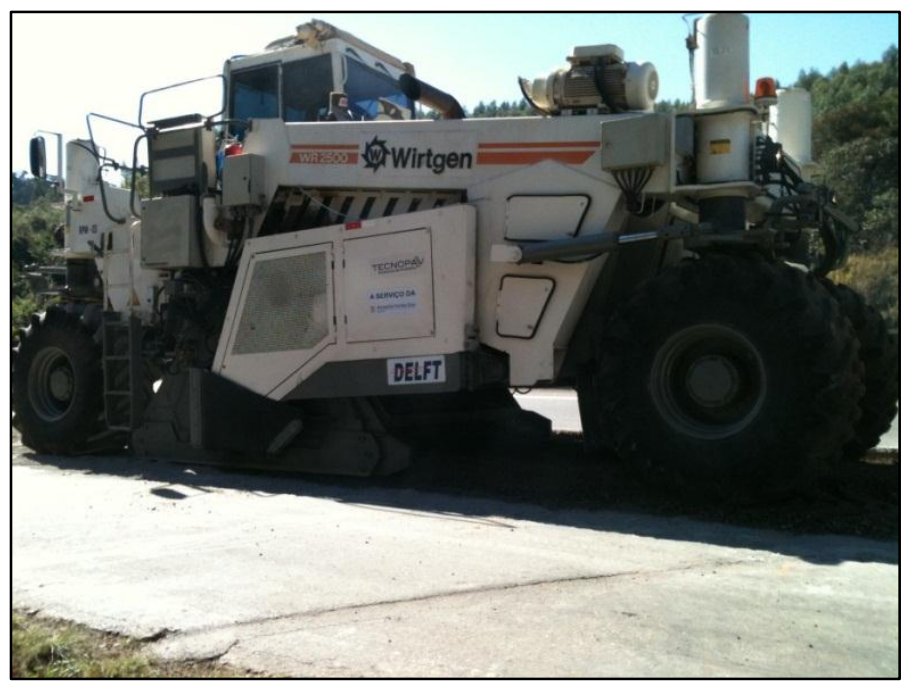

Figura 55 - Equipamento reciclador

No caso do trecho experimental onde há a variação da espesura da camada reciclada cimentada, o equipamento foi ajustado para respeitar o projeto, contemplando tais espessuras - Figura 56. Um rolo vibratório corrugado seguiu a recicladora para realizar a compactação da camada - Figura 57.

De acordo com a especificação de DER/SP para misturas de solo-brita-cimento, o processo de execução da camada deve respeitar o prazo máximo de 3 horas após o lançamento da água na mistura (DER/SP, 2006). Esse prazo deve ser respeitado uma vez que o fim da pega do cimento ocorre dentro desse período, não sendo possível proceder com o processo de compactação após essa fase (MEHTA; MONTEIRO, 2008).

O acabamento final da camada é realizado com auxilio de uma moto-niveladora Figura 57. A camada executada recebeu uma pintura ligação com emulsão asfáltica, a fim de evitar a perda de umidade para o ambiente, além de promover a ligação necessária com a camada seguinte (mistura reciclada com emulsão). 


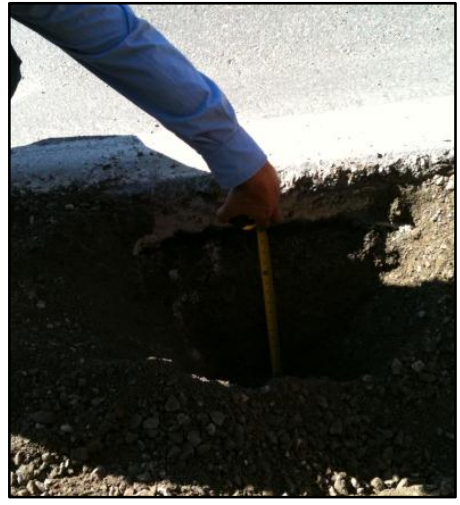

Figura 56 - Medição da profundidade da camada

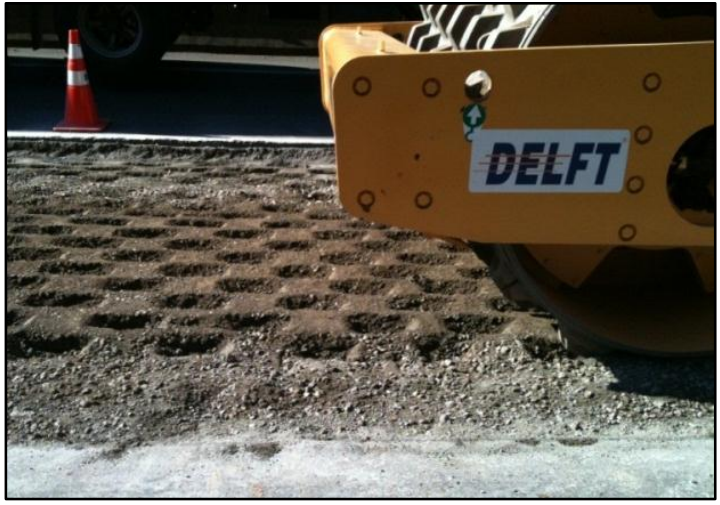

Figura 57 - Compactação da camada reciclada com cimento

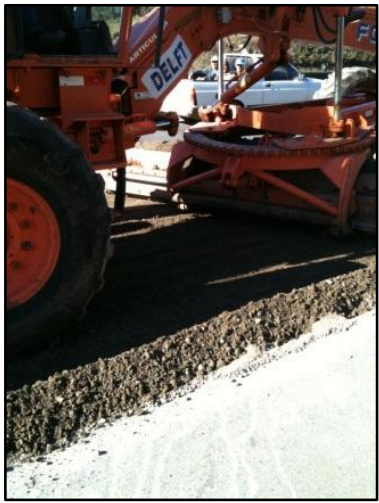

Figura 58 -

Finalização da camada reciclada com cimento

O processo de cura das misturas cimentadas é consideravelmente longo, entendese que o processo de hidratação do cimento é concluído em um período de 28 dias, no entanto, após os primeiros dias, é considerado que a mistura já apresenta rigidez suficiente para resistir aos novos esforços, como o de compactação de sobrecamadas e do tráfego. A execução da camada reciclada com emulsão do trecho experimental aqui descrito ocorreu após 72 horas da execução da camada reciclada com cimento. Períodos mais longos de espera são dificultados por problemas operacionais na via, devido ao elevado volume de tráfego.

O controle de execução consistiu da medição da profundidade da camada após a execução e da verificação da umidade da mistura, através da determinação do teor de umidade em campo e da compactação de corpos de prova (Figura 59).
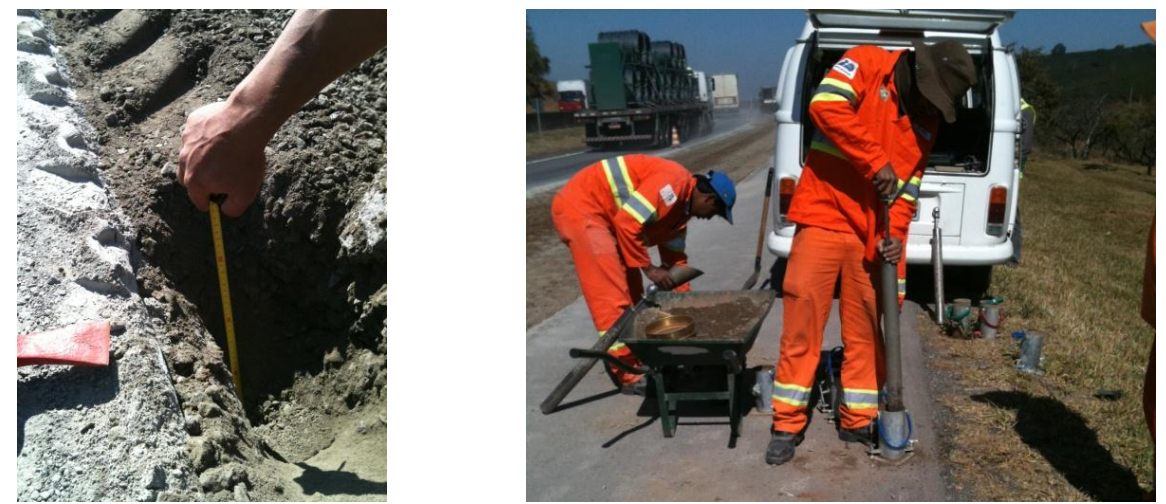

Figura 59 - Controle de execução da obra 


\subsection{MONITORAMENTO DO TRECHO EXPERIMENTAL}

A condição estrutural dos pavimentos é medida através de ensaios não destrutivos, onde são medidos os deslocamentos verticais na superfície do pavimento quando da aplicação de uma carga conhecida. Quanto menores os deslocamentos, mais rígida é a estrutura de camadas avaliada.

No trecho experimental foi utilizado o FWD - Falling Weight Deflectometer, para as medidas de deflexão. Nesse ensaio uma carga circular padrão é aplicada no pavimento enquanto sensores medem o deslocamento vertical sofrido na superfície. Os deslocamentos recuperáveis gerados na superfície do pavimento são computados por sete geofones instalados na placa de carga e ao longo de uma barra metálica. Costuma-se empregar os seguintes espaçamentos para os geofones: 0, 200, 300, 450, 650, 900 e 1200 mm. Através das sete leituras é possível obter a bacia de deflexões, que é uma medida da resposta da estrutura do pavimento à solicitação do ensaio.

Foram realizados dois levantamentos de deflexões no trecho experimental sendo o primeiro realizado um mês após sua construção (setembro de 2011) e o segundo realizado após um ano de abertura ao tráfego (setembro de 2012).

\subsubsection{Primeiro Levantamento Deflectométrico}

No primeiro levantamento foram levantadas bacias de deflexão em seis pontos para cada um dos segmento de $250 \mathrm{~m}$ do trecho experimental. As bacias de deflexões levantadas para cada segmento são apresentadas nos gráficos que seguem. Verifica-se na Figura 60 que o trecho de camada cimentada de $20 \mathrm{~cm}$ de espessura apresentou uma elevada dispersão de leituras, além de maiores deflexões máximas, quando comparado com os resultados apresentados na Figura 61 e na Figura 62, para o segmento com 25 e $30 \mathrm{~cm}$ de camada cimentada, respectivamente. 


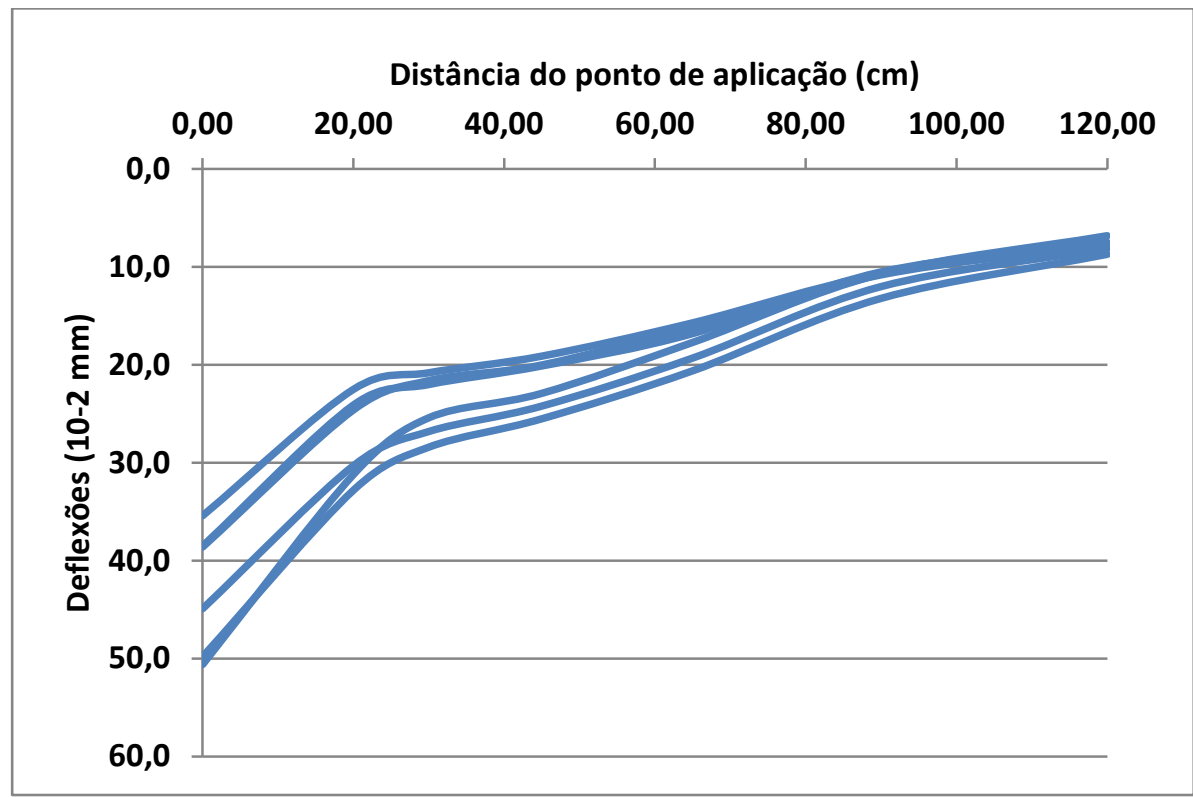

Figura 60 - Primeiro levantamento deflectométrico - Segmento de $20 \mathrm{~cm}$ de camada reciclada com cimento

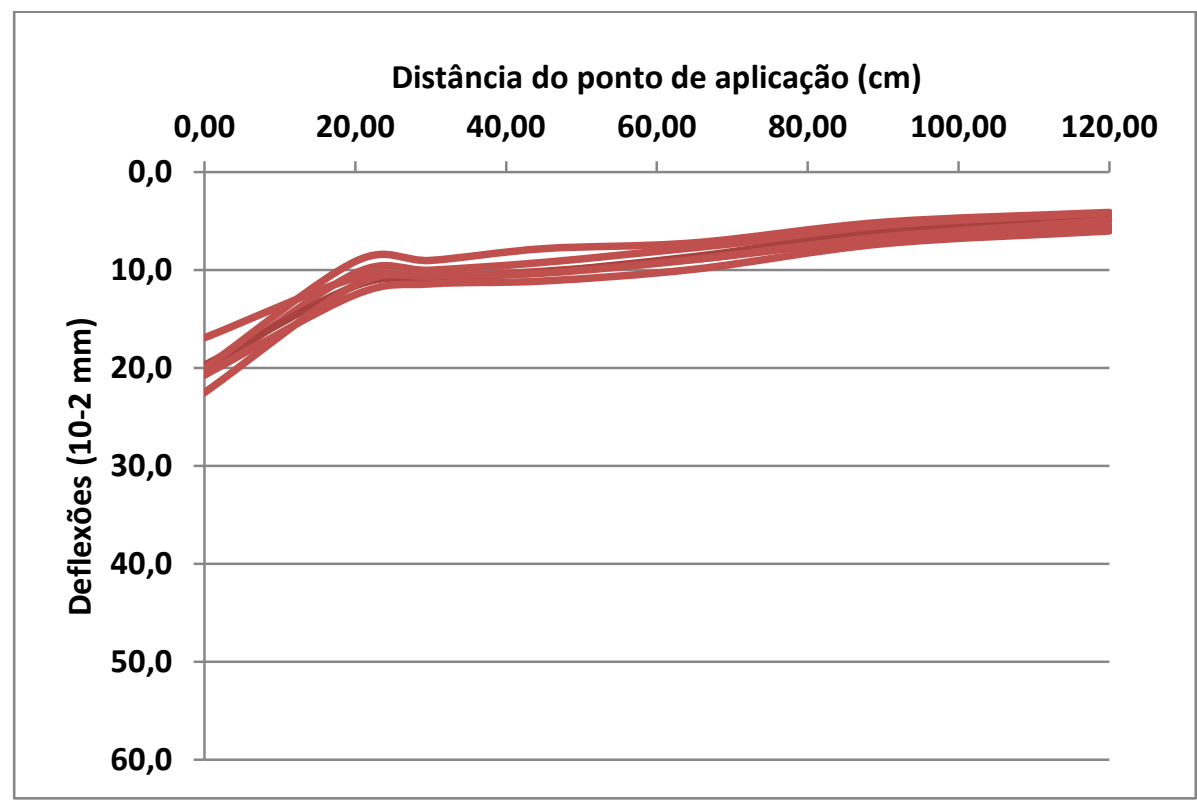

Figura 61 - Primeiro levantamento deflectométrico - Segmento de $25 \mathrm{~cm}$ de camada reciclada com cimento 


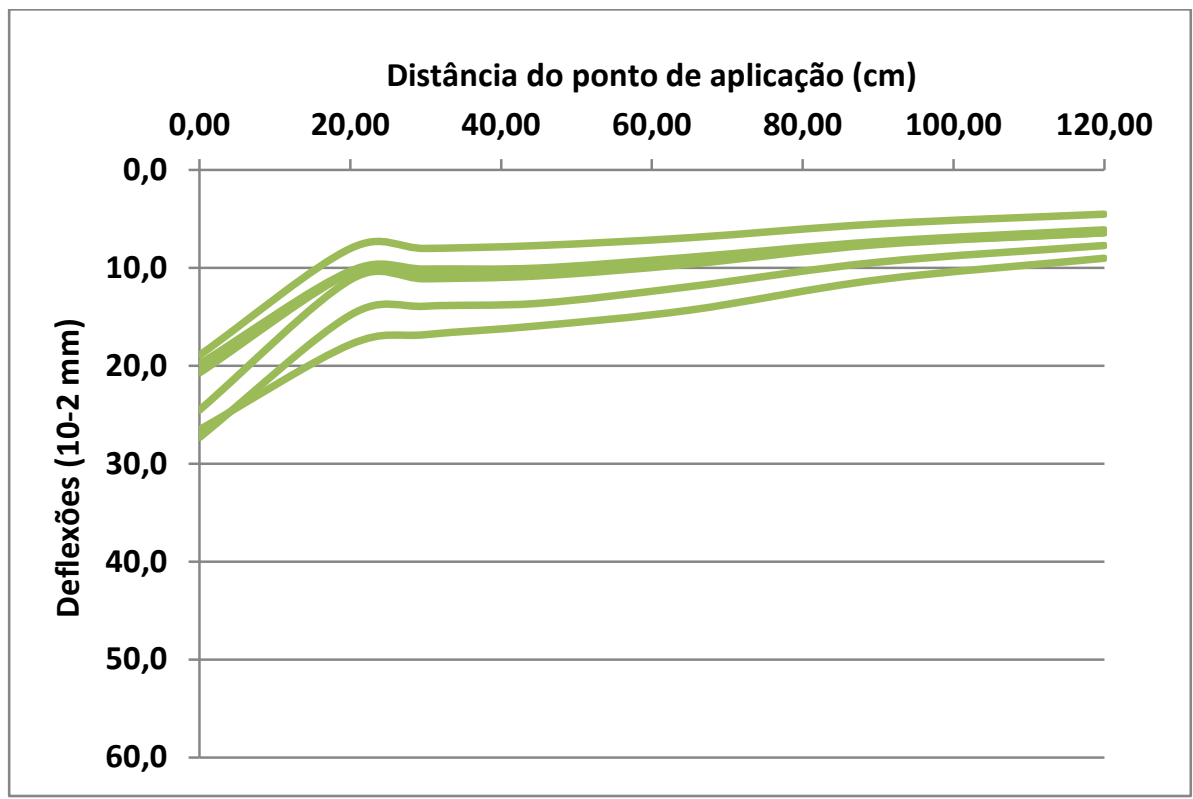

Figura 62 - Primeiro levantamento deflectométrico - Segmento de $30 \mathrm{~cm}$ de camada reciclada com cimento

Acredita-se que o segmento com $20 \mathrm{~cm}$ de espessura de camada cimentada apresentou deflexões mais elevadas, decorrentes da condição da infraestrutura remanescente. As leituras do FWD nesse segmento apresentaram desvio padrão no ponto de máxima deflexão igual $6,4 \times 10^{-2} \mathrm{~mm}$, superior aos segmentos de $25 \mathrm{~cm}$ e $30 \mathrm{~cm}$ de base cimentada, que apresentaram desvio padrão de $1,8 \times 10^{-2} \mathrm{~mm} e$ $3,6 \times 10^{-2} \mathrm{~mm}$, respectivamente.

A elevada dispersão de resultados e as deflexões máximas de até $50 \times 10^{-2} \mathrm{~mm}$ são o primeiro indicativo de possíveis problemas estruturais no segmento de $20 \mathrm{~cm}$ de camada cimentada reciclada. Os resultados de retroanálise e ensaios laboratoriais com amostras de campo, apresentados nos itens a seguir irão reafirmar essa hipótese.

Para melhor visualização e comparação dos resultados obtidos para cada segmento do trecho experimental, foram calculadas bacias médias dos três segmentos de estudo. Para a obtenção dessas bacias médias foram eliminadas as leituras de FWD dos pontos de divisa entre segmentos com espessuras distintas de camada cimentda. O resumo dos levantamentos são apresentados no gráfico da Figura 63. 


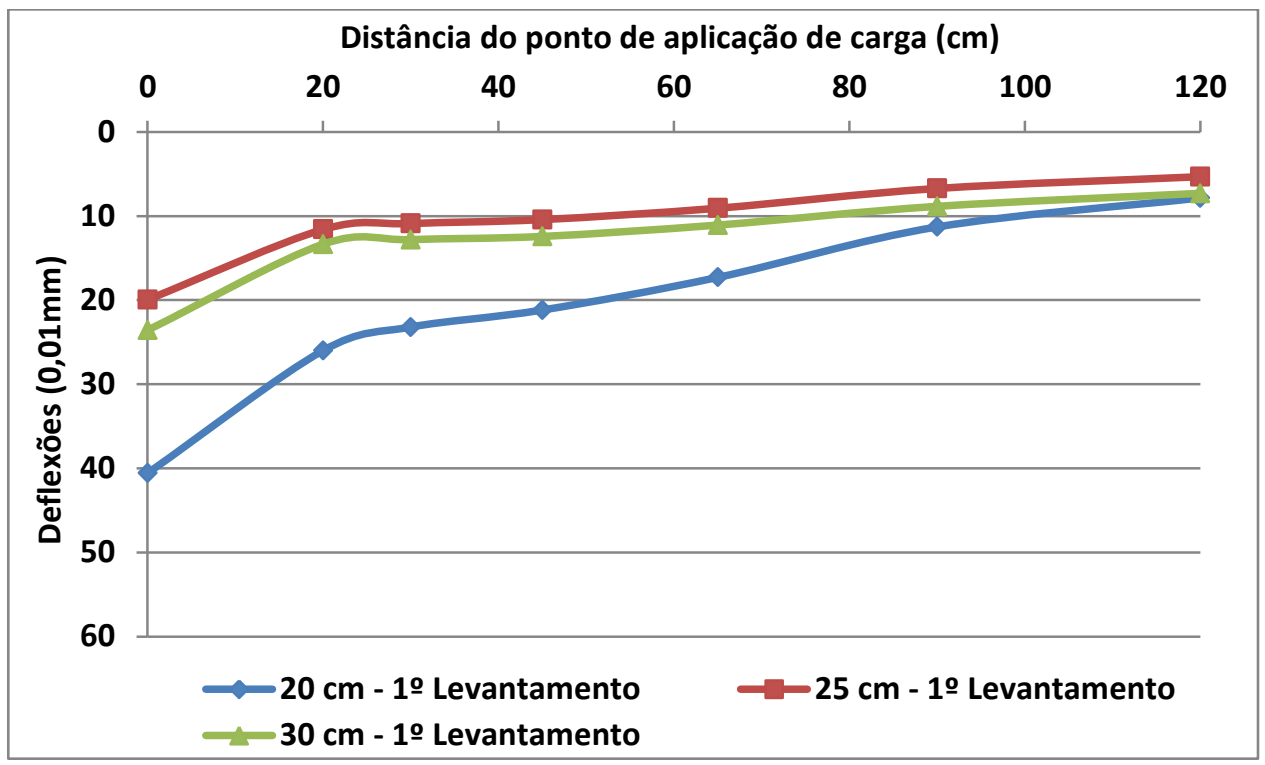

Figura 63 - Bacias de deflexão médias - Primeiro levantamento deflectométrico

A camada cimentada tem grande responsabilidade na rigidez do pavimento, portanto sua espessura influencia significativamente os resultados de deflexão.

Dos resultados apresentados na Figura 63, observa-se um comportamento semelhante entre a estrutrua com $25 \mathrm{~cm}$ de base reciclada e a estrutura com $30 \mathrm{~cm}$. Acredita-se que essa semelhança seja devido a uma ponderação de fatores como:

(i) variação na infraestrutura remanescente em cada um dos segmentos; e

(ii) possível variação de eficiência na compactação;

O primeiro levaria a melhores resultados para o segmento com $30 \mathrm{~cm}$, porém o segundo deixaria o trecho com $25 \mathrm{~cm}$ em melhores condições.

\subsubsection{Segundo Levantamento Deflectométrico}

No segundo levantamento deflectométrico foram levantadas 25 bacias para cada segmento de 250 metros do trecho experimental, proporcionando uma maior consistência nos dados e permitindo uma melhor análise dos resultados.

Verifica-se no gráfico apresentado na Figura 64 que o segmento com $20 \mathrm{~cm}$ de camada reciclada com cimento continua apresentado elevada dispersão nos 
resultados (desvio padrão de $10,0 \times 10^{-2} \mathrm{~mm}$ ), indicando elevada variação nas condições estruturais e corroborando os resultados obtidos no primeiro levantamento.

A tendência de resultados para os demais segmentos também se manteve. Os trechos de $25 \mathrm{~cm}$ (Figura 65) e de $30 \mathrm{~cm}$ de camada cimentada (Figura 66) apresentaram baixa dispersão de resultados, com desvios padrão nas deflexões máximas de $1,0 \times 10^{-2} \mathrm{~mm}$ e $1,5 \times 10^{-2} \mathrm{~mm}$, respectivamente. Além disso, suas deflexões máximas mantiveram-se semlhantes entre si e inferiores às do segmento de $20 \mathrm{~cm}$ de camada cimentada.

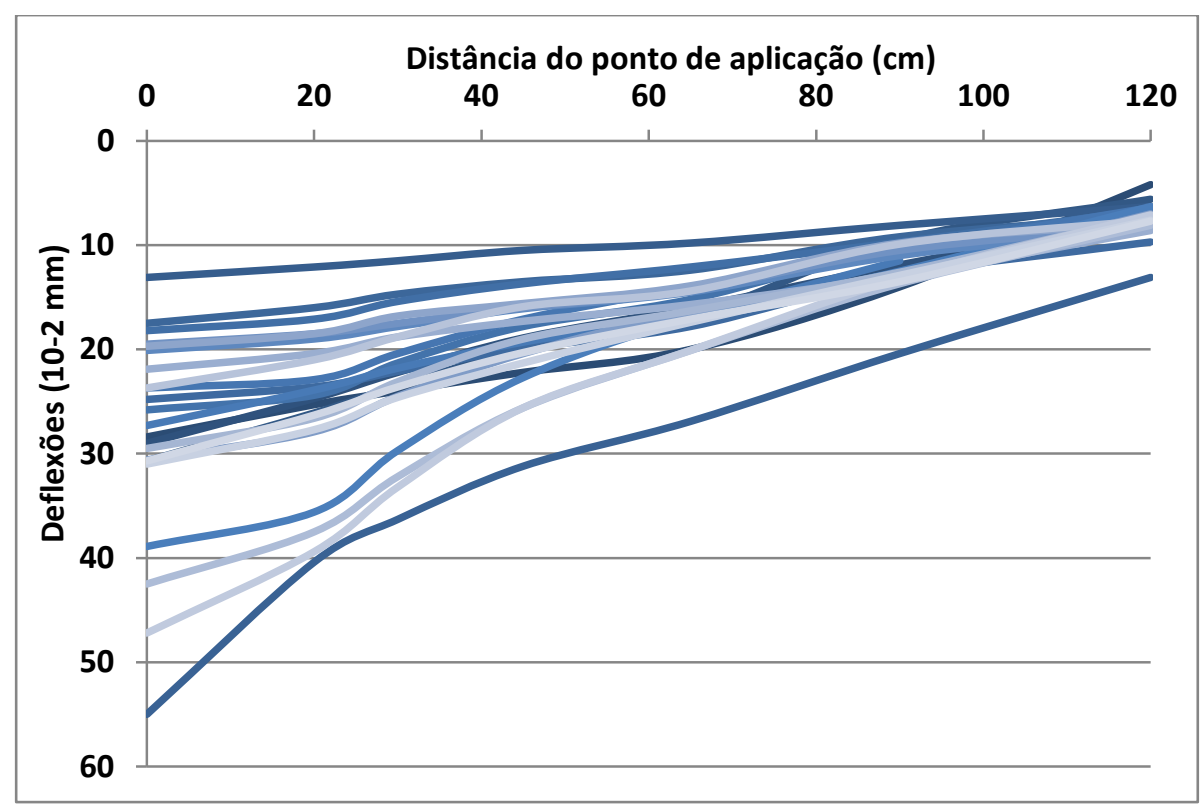

Figura 64 - Segundo levantamento deflectométrico -

Segmento de $20 \mathrm{~cm}$ de camada reciclada com cimento 


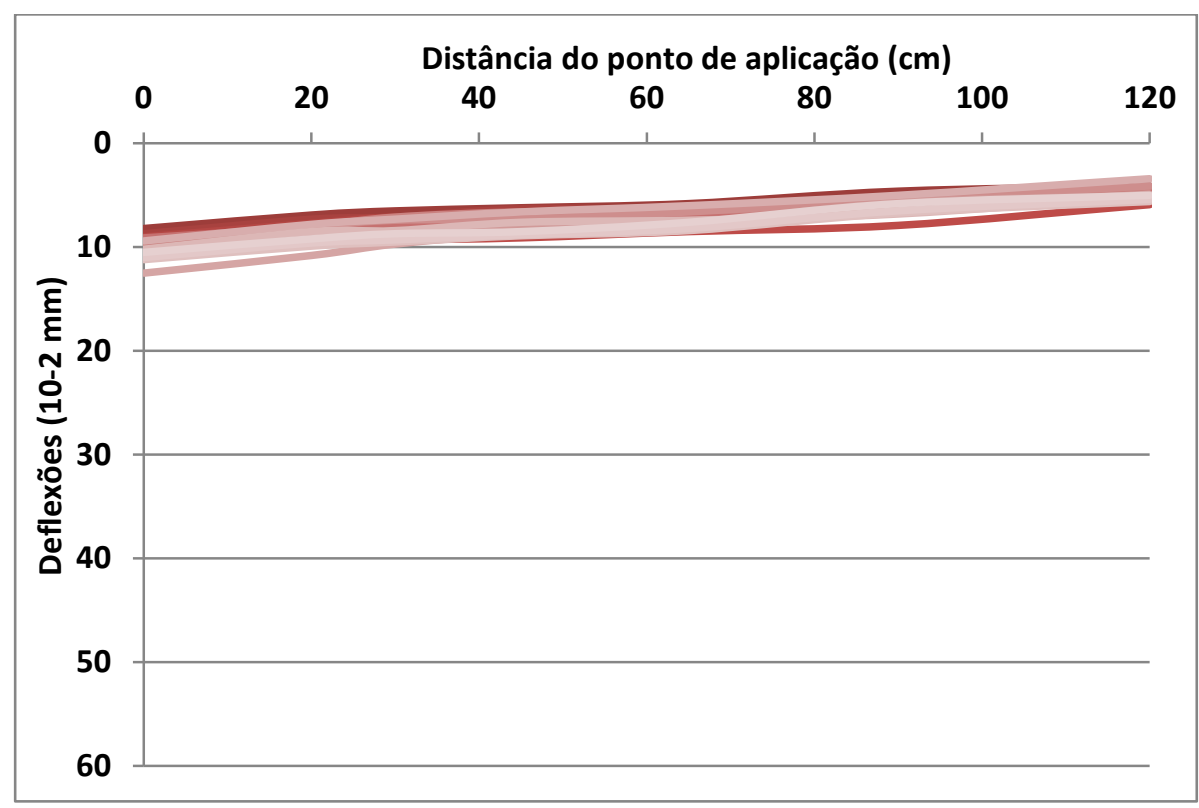

Figura 65 - Segundo levantamento deflectométrico - Segmento de $25 \mathrm{~cm}$ de camada reciclada com cimento

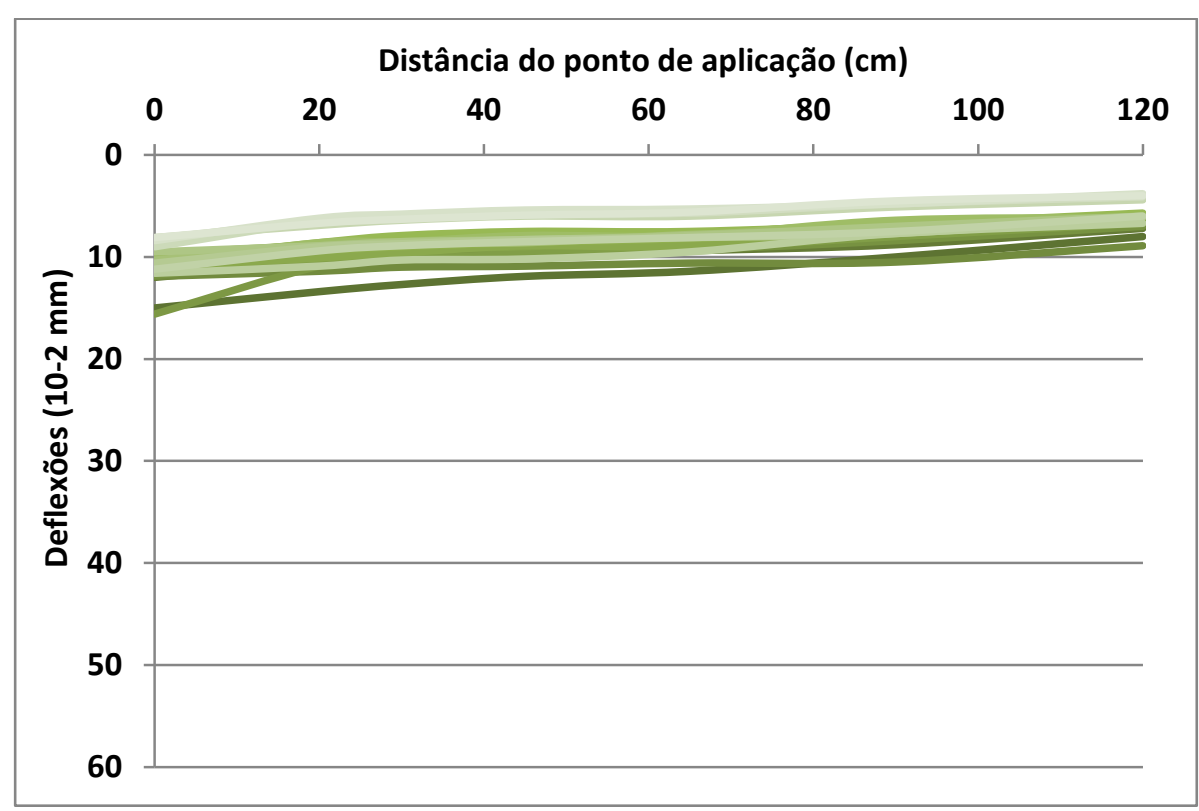

Figura 66 - Segundo levantamento deflectométrico - Segmento de $30 \mathrm{~cm}$ de camada reciclada com cimento

Para comparação entre os resultados obtidos dos dois levantamentos, os resultados médios são apresentados no gráfico da Figura 67. Verifica-se que em todos os casos houve diminuição das deflexões, indicando que o pavimento com um ano ainda não apresenta danos estruturais, principalmente na camada reciclada com 
cimento, já que ela é a principal responsável pela resposta estrutural desse pavimento.

A diminuição das deflexões pode ser explicada pelas condições de saturação do subleito e demais camadas. De acordo com dados do Instituto Nacional de Metereologia (INMET), o período do primeiro levantamento de deflexões (setembro de 2011) foi particularmente chuvoso naquela região, com médias de $10 \mathrm{~mm}$ de precepitação diária. Já durante o segundo levantamento de deflexões (setembro de 2012) a região se encontrava em período de seca com precipitações médias diárias de $0 \mathrm{~mm}$.

Outro fato a se ressaltar é a mudança no formato das bacias de deflexão. Nota-se que no primeiro levantamento havia um acúmulo de deformações na região do ponto de aplicação da carga, comportamento esse esperado de um pavimento flexível. No segundo levantamento, o formato da bacia é mais semelhante ao formato esperado para um pavimento rígido, podendo ser um indicativo do enrijecimento da estrutura do pavimento devido à consolidação dos materiais e condições climáticas favoráveis.

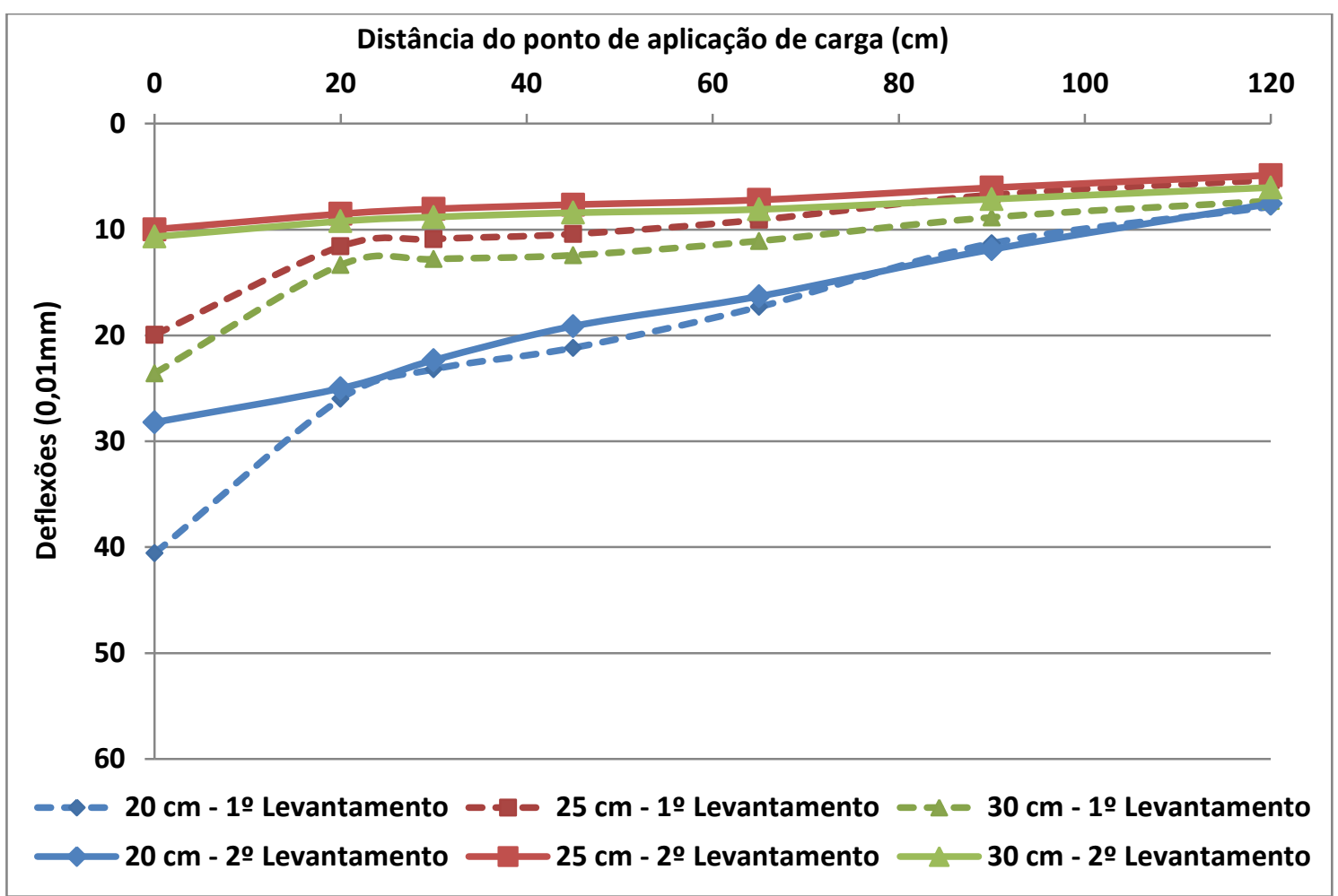

Figura 67 - Bacias de deflexão médias - Todos os levantamentos 


\subsubsection{Retroanálise}

A retroanálise avalia as deflexões na superfície da estrutura analisada, associadas aos módulos e espessuras das camadas, através de uma análise mecanicista. Para esta análise, pressupõe-se que as camadas sejam homogêneas, elásticas lineares e isotrópicas (para a maior parte dos softwares de análise).

Com base nos resultados das bacias de deflexão para os três segmentos do trecho experimental, nos dois levantamentos deflectométricos, foram obtidos os módulos de resiliência de cada camada do pavimento através do software para retroanálise BACKFAA.

Cada segmento, com variação da espessura da camada cimentada, foi definido como homogêneo, sendo as bacias características adotadas como a média das leituras realizadas, apresentadas na Figura 67.

\section{a) Camada Cimentada de $20 \mathrm{~cm}$}

Como consequência da diminuição das deflexões medidas nos segundo levantamento, os módulos de resiliência apresentados na Tabela 12 obtidos por retroanálise aumentaram, exceto na camada reciclada com cimento. Conforme comentado anteriormente, o segmento com $20 \mathrm{~cm}$ de camada cimentada apresentou problemas desde a execução, como evidenciado pelas deflexões medidas e, agora, pela retroanálise. Verifica-se que os valores de módulo de resiliência obtidos para essa camada não são comparáveis aos resultados de módulos de resiliência obtidos nos ensaios de corpos de prova de laboratório, apresentados no Capítulo 4.

Os resultados obtidos por retroanálise indicam que o problema estrutural detectado nesse segmento do trecho experimental é decorrente de falhas na camada reciclada com cimento. 
Tabela 12 - Resultados de MR por retroanálise $(20 \mathrm{~cm})$

\begin{tabular}{|c|c|c|c|}
\hline \multirow{2}{*}{ Camada } & \multirow{2}{*}{ Espessura } & \multicolumn{2}{|c|}{ MR (MPa) } \\
\cline { 3 - 4 } & & $\mathbf{1}$ Levantamento & $\mathbf{2}$ o Levantamento \\
\hline CBUQ & $4 \mathrm{~cm}$ & 3.000 & 3.590 \\
\hline REC. EMULSÃO & $7 \mathrm{~cm}$ & 270 & 1.060 \\
\hline REC. CIMENTO & $20 \mathrm{~cm}$ & 2.730 & 2.840 \\
\hline CANGA & $18 \mathrm{~cm}$ & 150 & 90 \\
\hline SUBLEITO & - & 100 & 110 \\
\hline
\end{tabular}

Os gráficos apresentados na Figura 68 e na Figura 69 mostram as aproximações das bacias de deflexões obtidas para os dois levantamentos com a utilização do software BAKFAA. Os limites definidos para aceitação dos resultados foram definidos como o desvio padrão dos resultados para o segmento homogêneo. Verifica-se que houve boa correlação entre as bacias medidas e as calculadas pelo software.

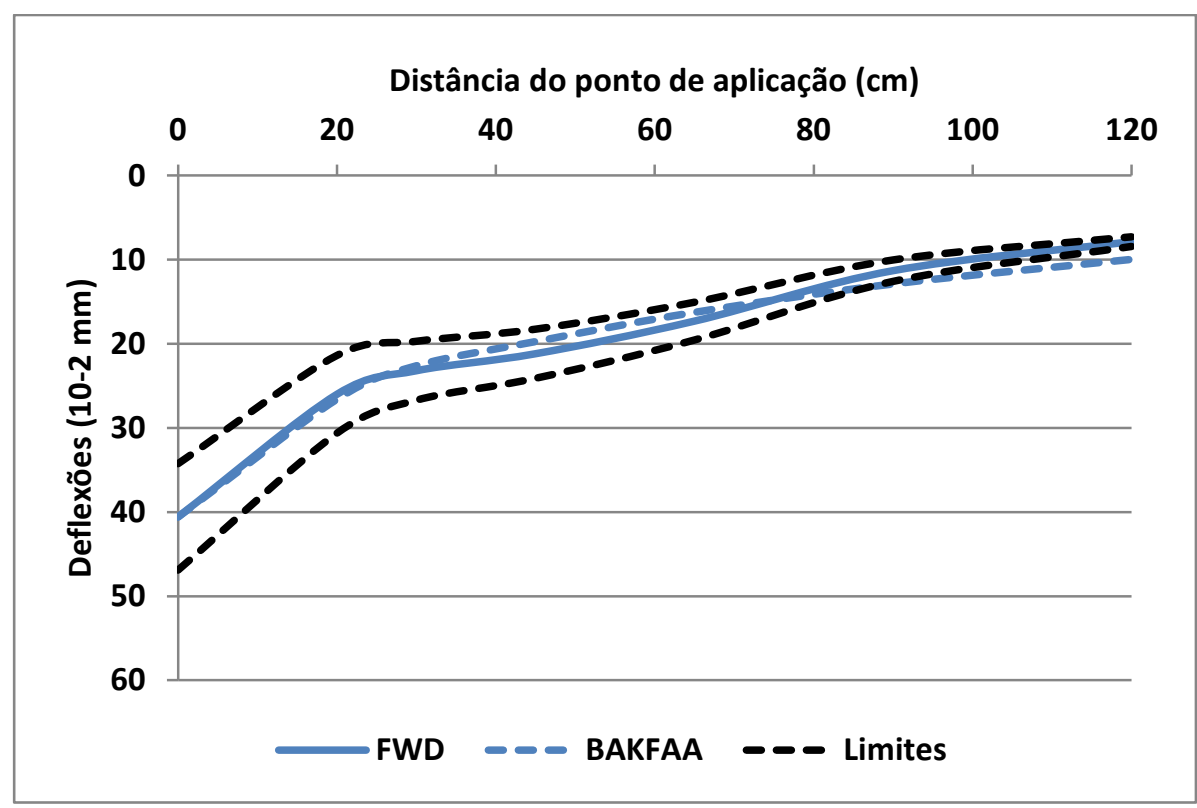

Figura 68 - Retroanálise da bacia média - 1 Levantamento - Segmento de $20 \mathrm{~cm}$ de camada reciclada com cimento 


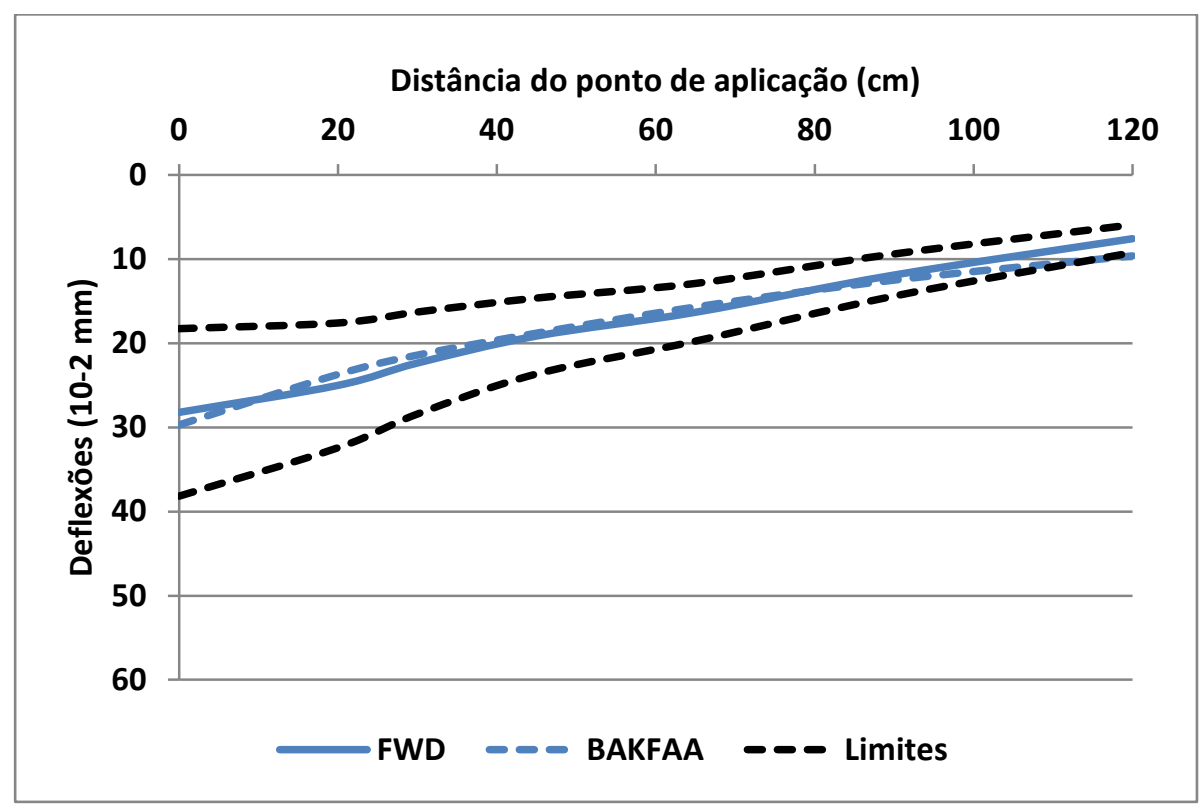

Figura 69 - Retroanálise da bacia média - 2o Levantamento - Segmento de $20 \mathrm{~cm}$ de camada reciclada com cimento

\section{b) Camada Cimentada de $25 \mathrm{~cm}$}

Os resultados de módulos de resiliência calculados por retroanálise são apresentados na Tabela 13. Nesse segmento também houve o aumento dos módulos de resiliência retroanalisados, decorrente da diminuição das deflexões. A camada cimentada apresentou novamente ganho de rigidez entre um levantamento e outro, indicando possível continuidade no processo de cura e consolidação nessa camada devido ao tráfego.

Tabela 13 - Resultados de MR por retroanálise $(25 \mathrm{~cm})$

\begin{tabular}{|c|c|c|c|}
\hline \multirow{2}{*}{ Camada } & \multirow{2}{*}{ Espessura } & \multicolumn{2}{|c|}{ MR (MPa) } \\
\cline { 3 - 4 } & & $\mathbf{1}$ Levantamento & 20 Levantamento \\
\hline CBUQ & $4 \mathrm{~cm}$ & 3.030 & 7.950 \\
\hline REC EMULSÃO & $7 \mathrm{~cm}$ & 520 & 3.610 \\
\hline REC CIMENTO & $25 \mathrm{~cm}$ & 7.720 & 18.730 \\
\hline CANGA & $13 \mathrm{~cm}$ & 160 & 400 \\
\hline SUBLEITO & - & 190 & 190 \\
\hline
\end{tabular}

Os gráficos apresentados na Figura 70 e na Figura 71 mostram as aproximações das bacias de deflexões obtidas para os dois levantamentos. Os limites definidos para aceitação dos resultados foram os mesmos utilizados no segmento de $20 \mathrm{~cm}$ 
de camada cimentada. Como as leituras para o segmento de $25 \mathrm{~cm}$ de camada cimentada apresentaram menor dispersão, os limites de aceitação foram muito inferiores, contudo ainda verificou-se boa correlação entre as bacias medidas e as calculadas pelo software.

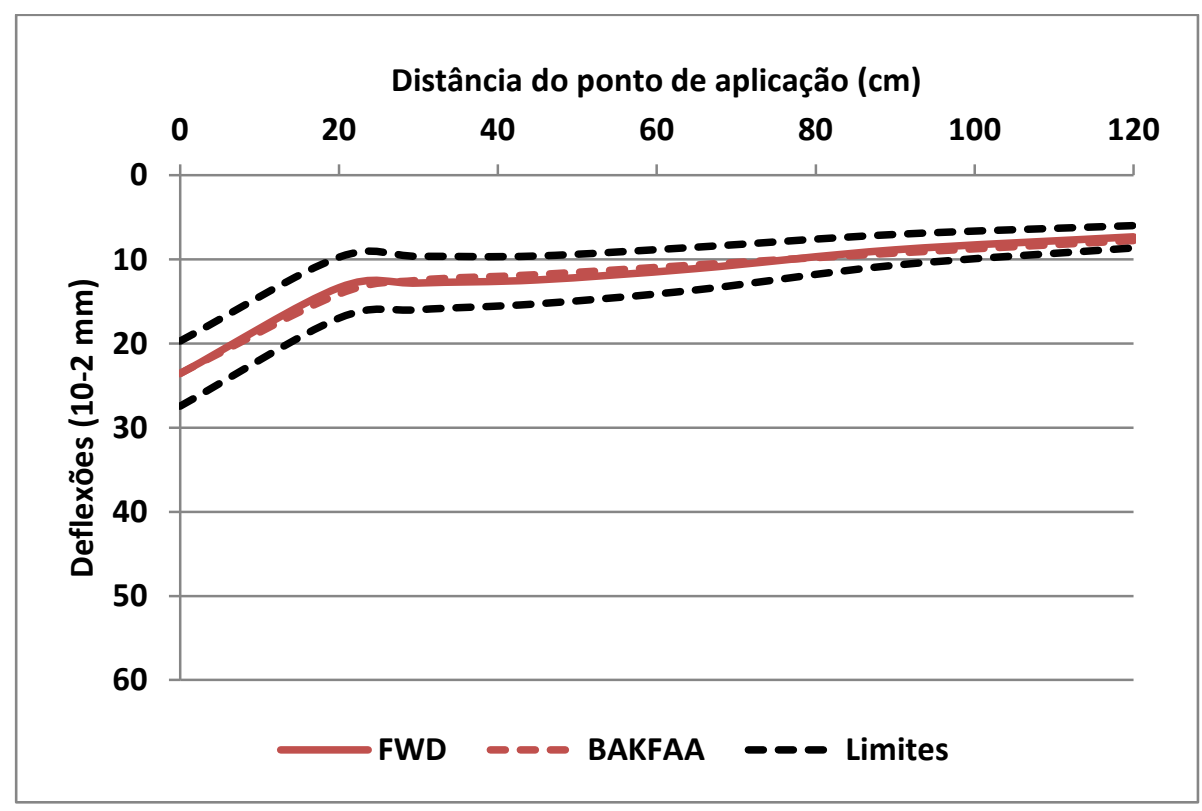

Figura 70 - Retroanálise da bacia média - 1 Levantamento - Segmento de $25 \mathrm{~cm}$ de camada reciclada com cimento

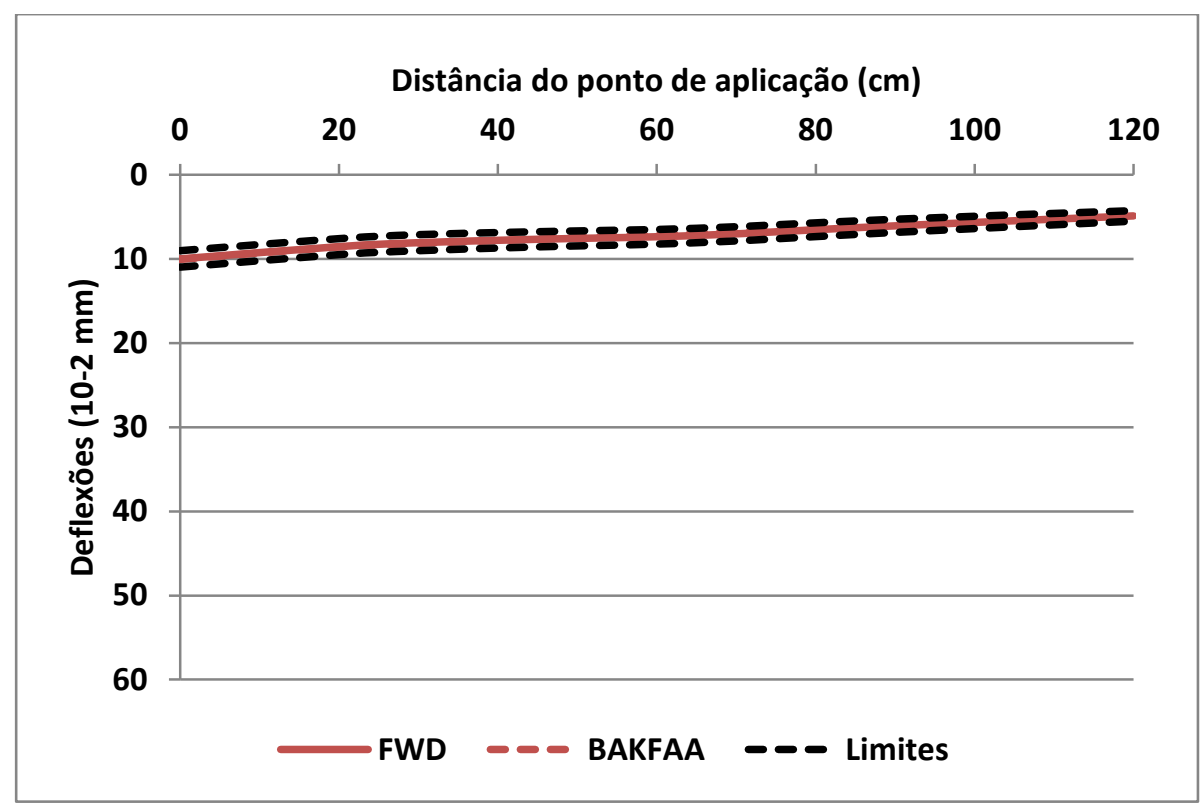

Figura 71 - Retroanálise da bacia média - 2o Levantamento - Segmento de $25 \mathrm{~cm}$ de camada reciclada com cimento 


\section{c) Camada Cimentada de $30 \mathrm{~cm}$}

Os resultados de módulos de resiliência calculados por retroanálise para o segmento com $30 \mathrm{~cm}$ de reciclagem com cimento são apresentados na Tabela 14. Como nos segmentos anteriores, esse segmento também apresentou aumento dos módulos de resiliência para um período de ano. A camada cimentada apresentou ganho de rigidez entre um levantamento e outro da mesma forma que o comentado para o segmento com $25 \mathrm{~cm}$ de camada cimentada.

Tabela 14 - Resultados de MR por retroanálise $(30 \mathrm{~cm})$

\begin{tabular}{|c|c|c|c|}
\hline \multirow{2}{*}{ Camada } & \multirow{2}{*}{ Espessura } & \multicolumn{2}{|c|}{ MR (MPa) } \\
\cline { 3 - 4 } & & $\mathbf{1}$ Levantamento & $\mathbf{2}$ Levantamento \\
\hline CBUQ & $4 \mathrm{~cm}$ & 2.560 & 8.450 \\
\hline REC EMULSÃO & $7 \mathrm{~cm}$ & 350 & 3.710 \\
\hline REC CIMENTO & $30 \mathrm{~cm}$ & 9.120 & 17.400 \\
\hline CANGA & $8 \mathrm{~cm}$ & 160 & 430 \\
\hline SUBLEITO & - & 130 & 140 \\
\hline
\end{tabular}

Os gráficos apresentados na Figura 72 e na Figura 73 mostram as aproximações das bacias de deflexões obtidas para os dois levantamentos. Os limites definidos para aceitação dos resultados foram os mesmos utilizados nos segmentos anteriores. Mais uma vez verificou-se boa correlação entre as bacias medidas e as calculadas pelo software. 


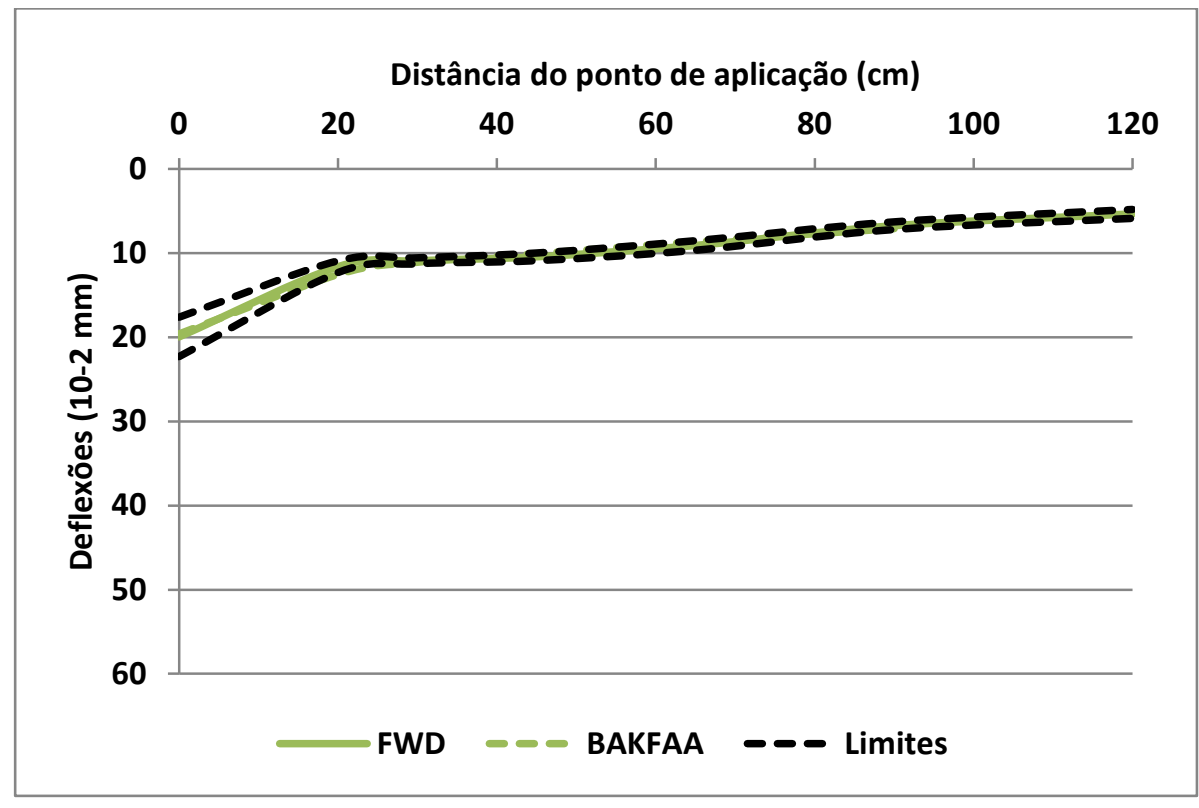

Figura 72 - Retroanálise da bacia média - 1 Levantamento - Segmento de $30 \mathrm{~cm}$ de camada reciclada com cimento

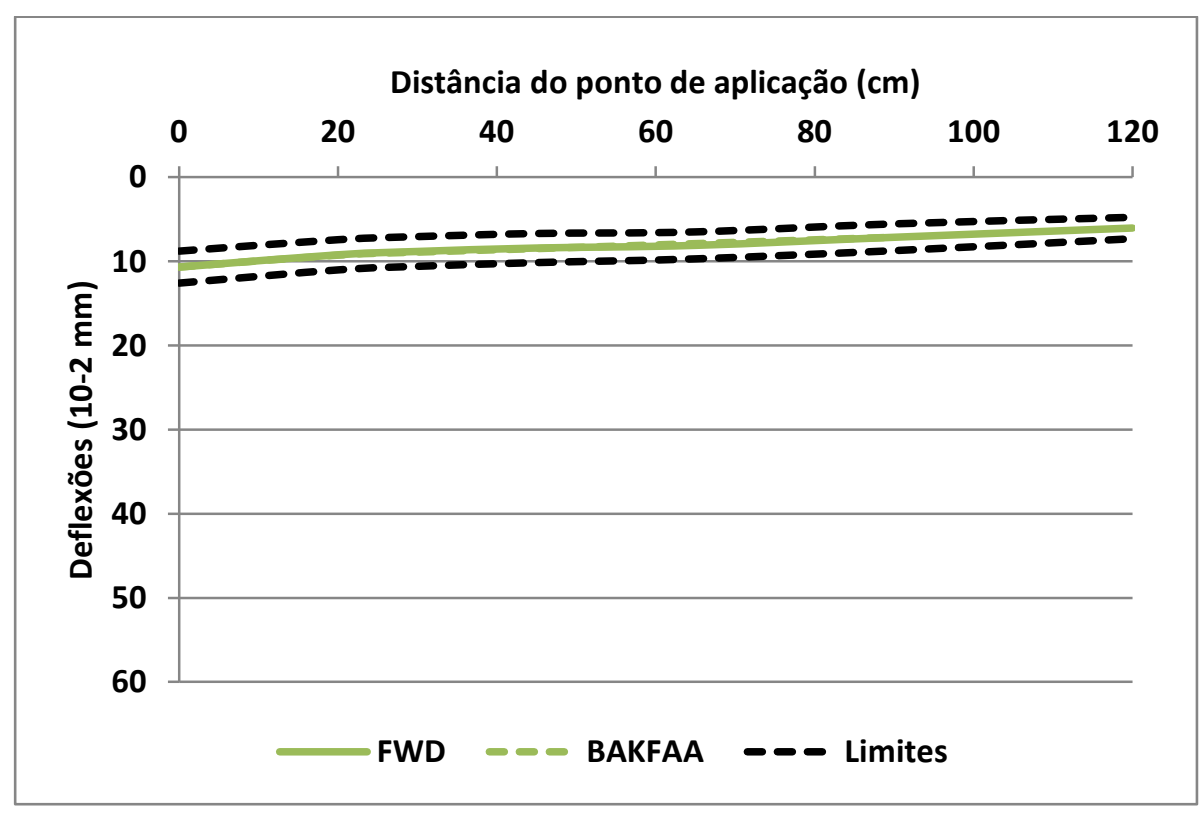

Figura 73 - Retroanálise da bacia média - 2o Levantamento - Segmento de $30 \mathrm{~cm}$ de camada reciclada com cimento 


\subsection{Estudo Laboratorial}

Com a modernização de equipamentos de campo acredita-se que seja possível obter uma compactação mais eficiente das camadas durante a execução, possibilitando a adoção de camadas mais espessas. Com os ensaios de laboratório tentou-se identificar se a execução de camadas mais espessas consegue atingir um grau de compactação suficiente. De forma geral, pretendeu-se detectar se essas camadas apresentam uma rigidez satisfatória e homogênea, mesmo quando compactadas em espessuras mais robustas, além de verificar se existe diferença no comportamento mecânico em função da espessura compactada.

Trinta corpos de prova foram extraídos de campo, sendo dez de cada segmento e cinco do eixo e cinco da trilha externa. Eles foram levados ao laboratório para a verificação das características de rigidez e resistência. A extração ocorreu em duas etapas 7 e 8 meses após a execução do trecho experimental, portanto acredita-se que sua cura já havia sido completa. A proximidade dos dois levantamentos deveuse a alguns problemas executivos encontrados durante a extração do primeiro grupo (7 meses), onde alguns corpos de prova não puderam ser ensaiados. Dessa forma, realizou-se a segunda campanha de extração aos 8 meses.

Para a retirada dos corpos de prova do material reciclado com cimento, a camada de concreto asfáltico usinado à quente e a camada de material reciclado com emulsão precisaram ser removidas, a fim de expor a camada subjacente. Em seguida os corpos de prova foram broqueados com uma extratora que cortou a camada de pavimento até a profundidade de interesse. Após a retirada dos corpos de prova, a janela aberta foi fechada e as camadas dos corpos de prova separadas e conduzidas ao laboratório. A Figura 74 ilustra algumas etapas desse processo. 

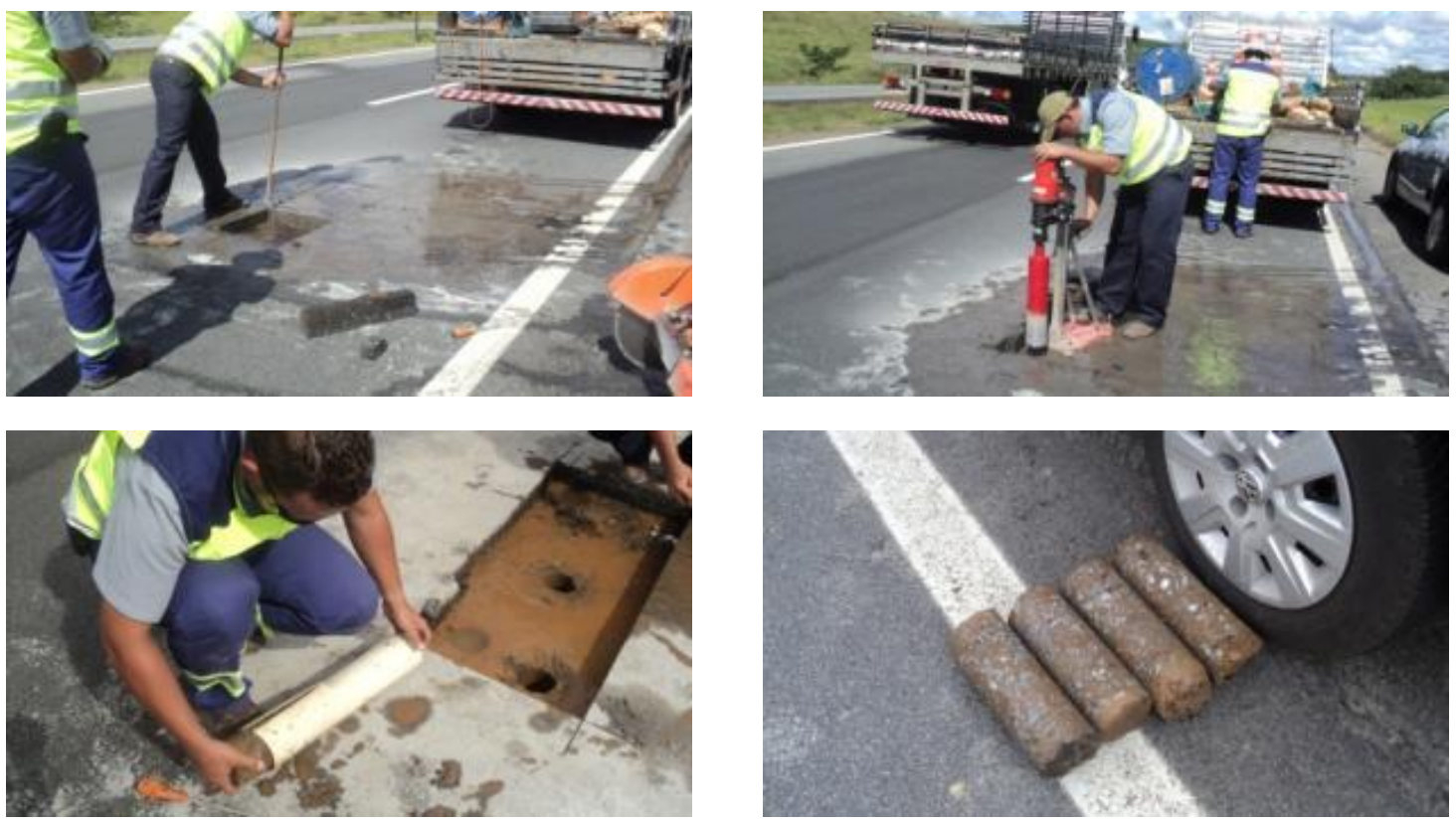

Figura 74 - Extração de corpos de prova em campo

Os corpos de prova das três camadas recicladas com cimento, variando as espessuras $(20 \mathrm{~cm}, 25 \mathrm{~cm}, 30 \mathrm{~cm})$, foram faceadados de forma a obter corpos de prova de $20 \mathrm{~cm}$ de altura (atendendo aos padrões dos equipamentos para realização dos ensaios mecânicos em laboratório). Os corpos de prova com espessura superior a $20 \mathrm{~cm}$ foram cortados, selecionando-se para os ensaios a parte inferior da camada, com o objetivo de ensaiar a região da camada onde poderiam ser identificados problemas de compactação.

Os corpos de prova da camada com $20 \mathrm{~cm}$ de reciclagem com cimento apresentaram problemas por não ter altura sufuciente para a realização dos ensaios e/ou segregação dos agregados conforme ilustrado na Figura 75. Por esse motivo poucos ensaios foram realizados com corpos de prova dessa camada.

Os corpos de prova de pista foram submetidos a três ensaios distintos para verificação de parâmetros de rigidez:

(i) Ensaio de Ultrassom

(ii) Ensaio de Módulo de Resiliência

(iii) Ensaio de Módulo de Elasticidade 
Optou-se por determinar o módulo de resliência e o módulo de elasticidade pelas razões apresentadas no mesmo comparativo realizado na etapa de laboratório (Capitulo 4).

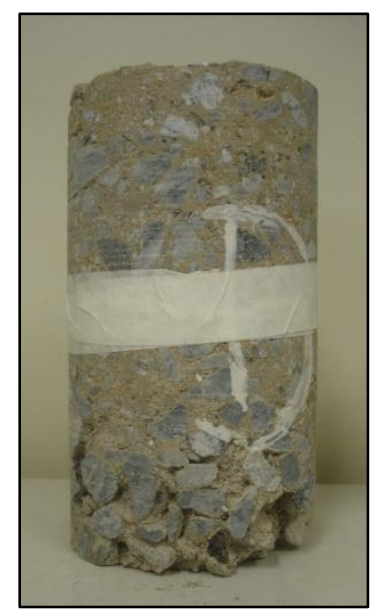

Figura 75 - Corpo de prova com altura insuficente e segregado

\subsubsection{Ultrassom}

Esse ensaio tem o objetivo de testar a integride de amostras através da medida da velocidade de propagação de uma onda de ultrassom. O equipamento é amplamente utilizado em estruturas e corpos de prova de concreto onde, após anos de testes, já se pode correlacionar a velocidade de propagação da onda com o módulo de elasticidade do concreto. Para o material reciclado em estudo, ainda não existem tais correlações, contudo é sabido que quanto maior a rigidez do material (que também pode estar associada a um menor volume de vazios), maior será a velocidade de propagação da onda de ultrassom. A Figura 76 ilustra algumas etapas de execução do ensaio.
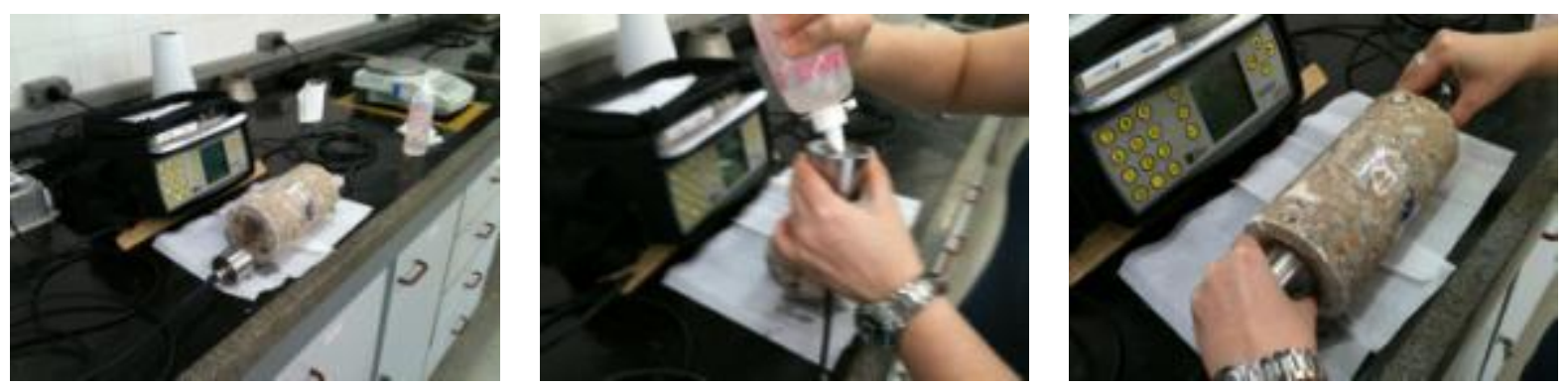

Figura 76 - Ilustração do ensaio de ultrassom 
As amostras de material de base reciclada com cimento extraídas de campo foram testadas no equipamento de ultrassom a fim de se obter um comparativo de rigidez dentre o grupo de amostras extraídas dos diferentes segmentos. Os resultados médios (Tabela 15) apresentam baixa variabilidade em função da espessura da camada, ou posição de extração do corpo de prova. Dessa forma, não foi possível observar diferença significatica entre a rigidez para as diferentes espessuras de camada cimentada, já que a velocidade de propagação das ondas não apresentou variação significativa.

Tabela 15 - Resultados dos ensaios de ultrassom

\begin{tabular}{|c|c|c|c|c|}
\hline $\begin{array}{c}\text { Espessura da } \\
\text { Camada }\end{array}$ & Posição & $\begin{array}{c}\text { Idade das } \\
\text { Amostras }\end{array}$ & $\begin{array}{c}\text { Velocidade } \\
\text { Média } \mathbf{( k m / s )}\end{array}$ & $\begin{array}{c}\text { Desvio Padrão } \\
\mathbf{( k m / s )}\end{array}$ \\
\hline \multirow{2}{*}{$20 \mathrm{~cm}$} & Eixo & 7 meses & 2,9 & 0,1 \\
\cline { 2 - 5 } & Trilha Externa & 8 meses & - & - \\
\hline \multirow{2}{*}{$25 \mathrm{~cm}$} & Eixo & 8 meses & 2,7 & 0,2 \\
\cline { 2 - 5 } & Trilha Externa & 8 meses & 3,4 & 0,3 \\
\hline \multirow{2}{*}{$30 \mathrm{~cm}$} & Eixo & 7 meses & 3,1 & 0,3 \\
\cline { 2 - 5 } & Trilha Externa & 8 meses & 3,0 & 0,2 \\
\hline
\end{tabular}

\subsubsection{Módulo de Resiliência Triaxial}

Assim como nos corpos de prova moldados em laboratório, os corpos de prova extraídos de campo foram submetidos ao ensaio de módulo de resiliência triaxial (Figura 77) com o objetivo de determinar essa grandeza para o material efetivamente aplicado em campo. Vale salientar que entre os corpos de prova extraídos de campo nenhum é exatamente o mesmo, peculiaridade de materiais reciclados, especialmente in situ. 

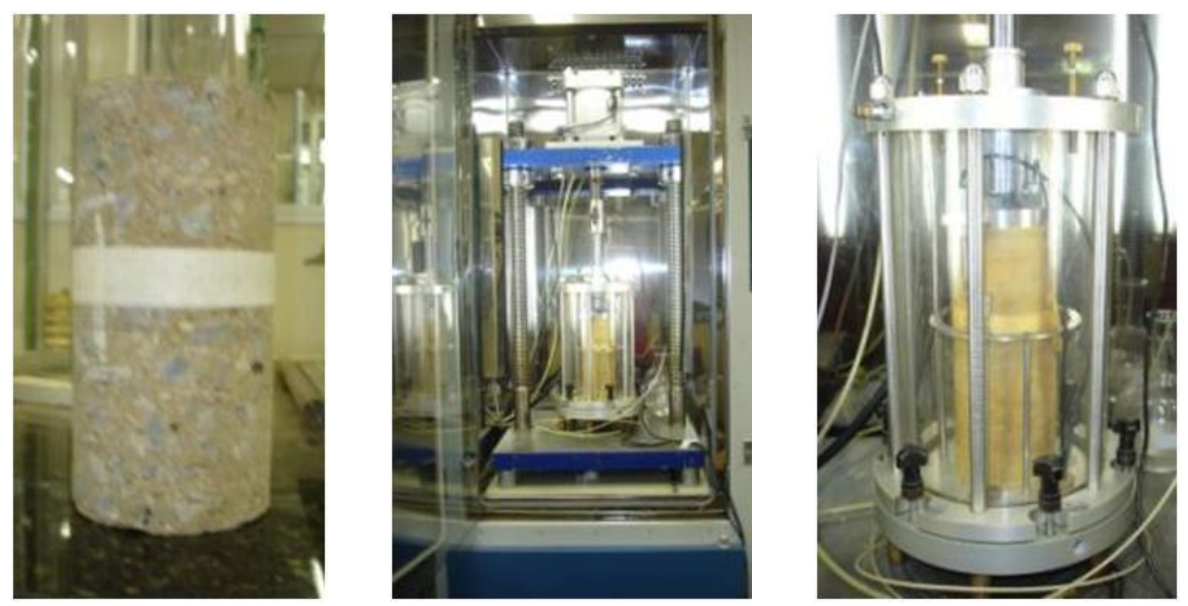

Figura 77 - llustração do ensaio de módulo de resiliência triaxial

Conforme citado, foram extraídos dez corpos de prova de cada espessura de camada cimentada, contudo nem todos os corpos de prova possuiam características para o ensaio, sendo elas altura suficiente e verticalidade da amostra. Como a instrumentação do ensaio de módulo de resiliência é muito dependente dessas caracteríscas poucos resultados foram obtidos com sucesso.

Os resultados são apresentados na Tabela 16. Adota-se como valor característico de módulo de resiliência, em ensaios triaxiais, o valor obtido com $0,1 \mathrm{MPa}$ de tensão confinante.

Tabela 16 - Resultados de ensaio de módulo de resiliência triaxial

\begin{tabular}{|c|c|}
\hline Espessura da Camada & MR (MPa) \\
\hline \multirow{2}{*}{$25 \mathrm{~cm}$} & 7761 \\
\cline { 2 - 2 } & 5708 \\
\hline \multirow{2}{*}{$30 \mathrm{~cm}$} & 8194 \\
\cline { 2 - 2 } & 6628 \\
\hline
\end{tabular}

Comparando-se os resultados verifica-se que não houve grande variação em resultados de módulo de resiliência para as camadas compactadas com 25 e $30 \mathrm{~cm}$, sugerindo que a compactação da camada mais espessa foi eficiente.

Os gráficos a seguir (Figura 78 e Figura 79) ilustram a influência da tensão de confinamento nos valores de módulo de resiliência. Verifica-se que os corpos de prova foram pouco dependentes da tensão de confinamento indicando comportamento diferente do comportamento observado em materiais granulares, 
esperado para misturas cimentadas. Ressalta-se que os resultados apresentados são de corpos de prova extraídos da trilha externa onde, teoricamente, houve maior consolidação pelo tráfego.

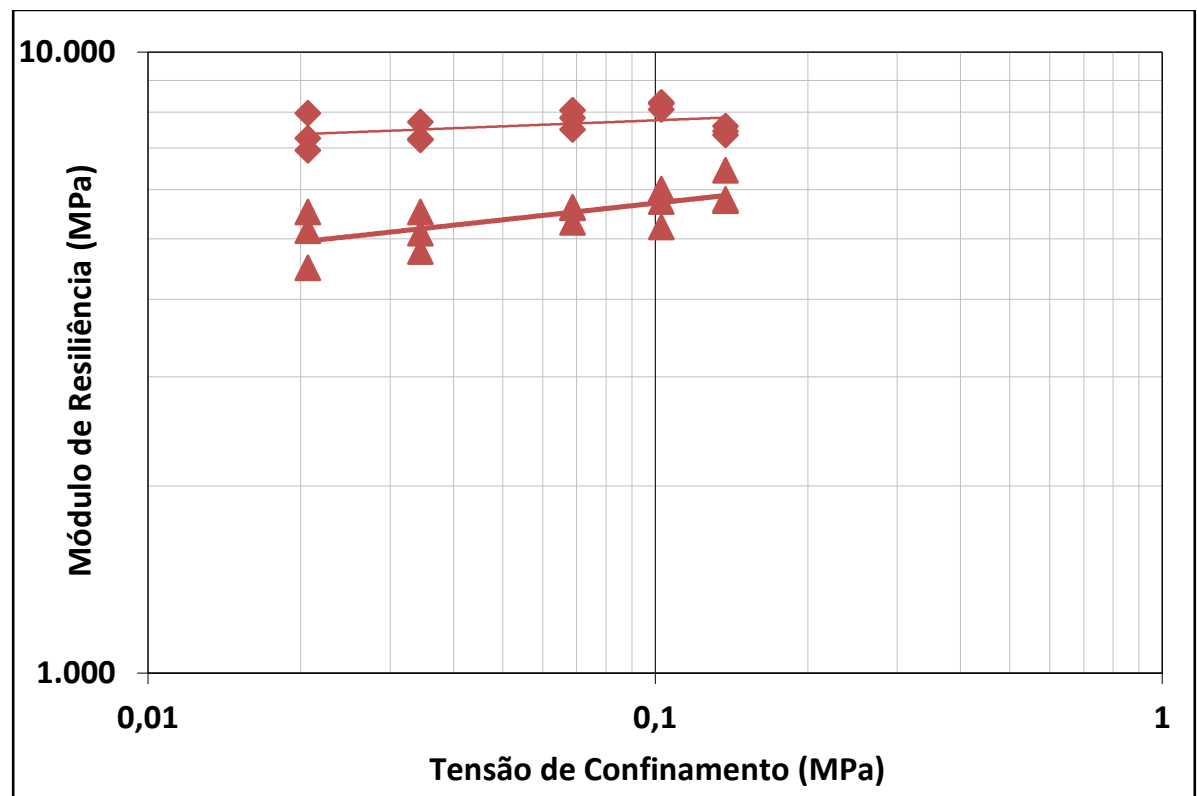

Figura 78 - Resultado de ensaio de MR triaxial - Camada de $25 \mathrm{~cm}$ de camada reciclada com cimento

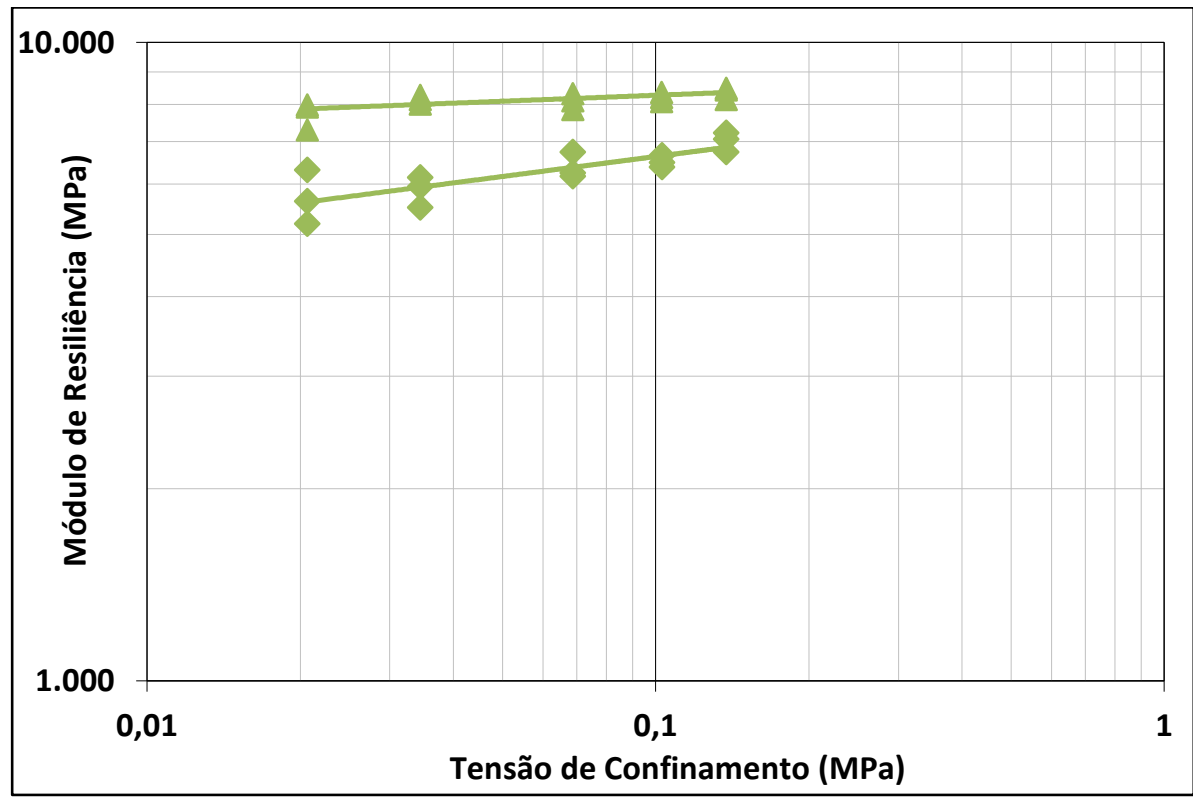

Figura 79 - Resultado de ensaio de MR triaxial - Camada de $30 \mathrm{~cm}$ de camada reciclada com cimento 


\subsubsection{Módulo de Elasticidade}

O ensaio de módulo de elasticidade (Figura 80 ) apresenta instrumentação mais simplificada que o ensaio de módulo de resiliência, tornando possível a determinação de tal parâmetro em um maior número de corpos de prova.
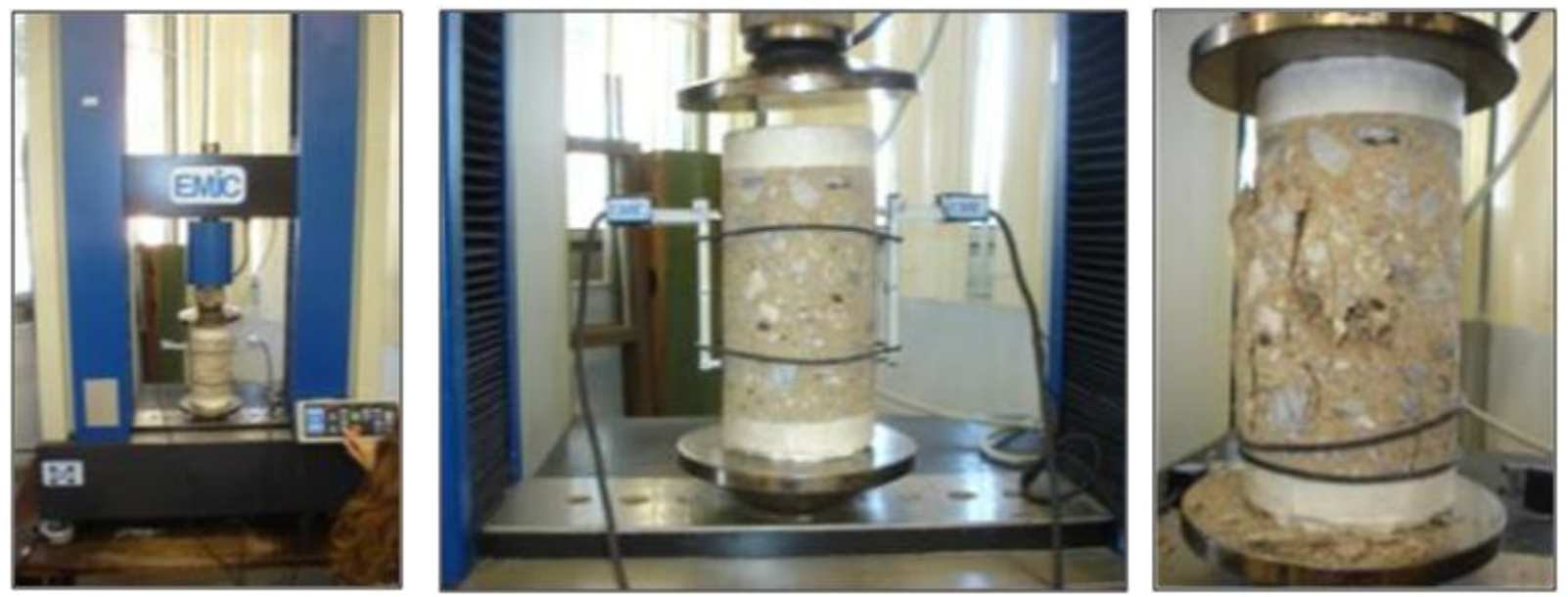

Figura 80 - llustração do ensaio de módulo de elasticidade

Os resultados obtidos são apresentados na Tabela 17. Não se observaram variações significativas entre os resultados de módulo de elasticidade para as camadas com diferentes espessuras quando os corpos de prova foram extraídos do eixo. Os valores obtidos para esse grupo de corpos de prova foi compatível aos obtidos para o módulo de elasticidade de corpos de prova moldados em laboratório (9000 MPa, aproximadamente).

Quando se compara os corpos de prova extaídos da trilha externa, verifica-se que a camada de $25 \mathrm{~cm}$ de espessura apresentou módulos de elasticidade bastante elevados em relação à camada com $30 \mathrm{~cm}$ de espessura, portanto o ensaio de módulo de elasticidade conseguiu diferenciar as camadas com diferentes espessuras de compactação.

Baseando-se nesses resultados pode-se inferir que houve consolidação da camada cimentada pelo tráfego e que essa consolidação ocorreu mais pronunciadamente na camada menos espessa. Esses resultados são sustentados pelos obtidos por retroanálise. 
Tabela 17 - Resultados de ensaio de módulo de elasticidade

\begin{tabular}{|c|c|c|c|c|}
\hline $\begin{array}{c}\text { Espessura } \\
\text { da Camada }\end{array}$ & Posição & $\begin{array}{c}\text { Número de } \\
\text { Amostras }\end{array}$ & ME (MPa) & $\begin{array}{c}\text { Desvio } \\
\text { Padrão (MPa) }\end{array}$ \\
\hline \multirow{2}{*}{$20 \mathrm{~cm}$} & Eixo & 1 & 8028 & - \\
\cline { 2 - 5 } & Trilha Externa & - & - & - \\
\hline \multirow{2}{*}{$25 \mathrm{~cm}$} & Eixo & 3 & 7996 & 992 \\
\cline { 2 - 5 } & Trilha Externa & 3 & 17083 & 2497 \\
\hline \multirow{2}{*}{$30 \mathrm{~cm}$} & Eixo & 5 & 9124 & 2418 \\
\cline { 2 - 5 } & Trilha Externa & 2 & 10416 & 2237 \\
\hline
\end{tabular}

\subsubsection{Módulo de Resiliência versus Módulo de Elasticidade}

O gráfico da Figura 81 ilustra os valores médios obtidos para módulo de resiliência e módulo de elasticidade nas amostras de pista. Comparando-se esses dois parâmetros de rigidez, conforme foi feito para corpos de prova moldados em laboratório, verifica-se que os valores obtidos para módulo de elasticidade são superiores aos obtidos para módulo de resiliência, como já discutido no Capítulo 4.

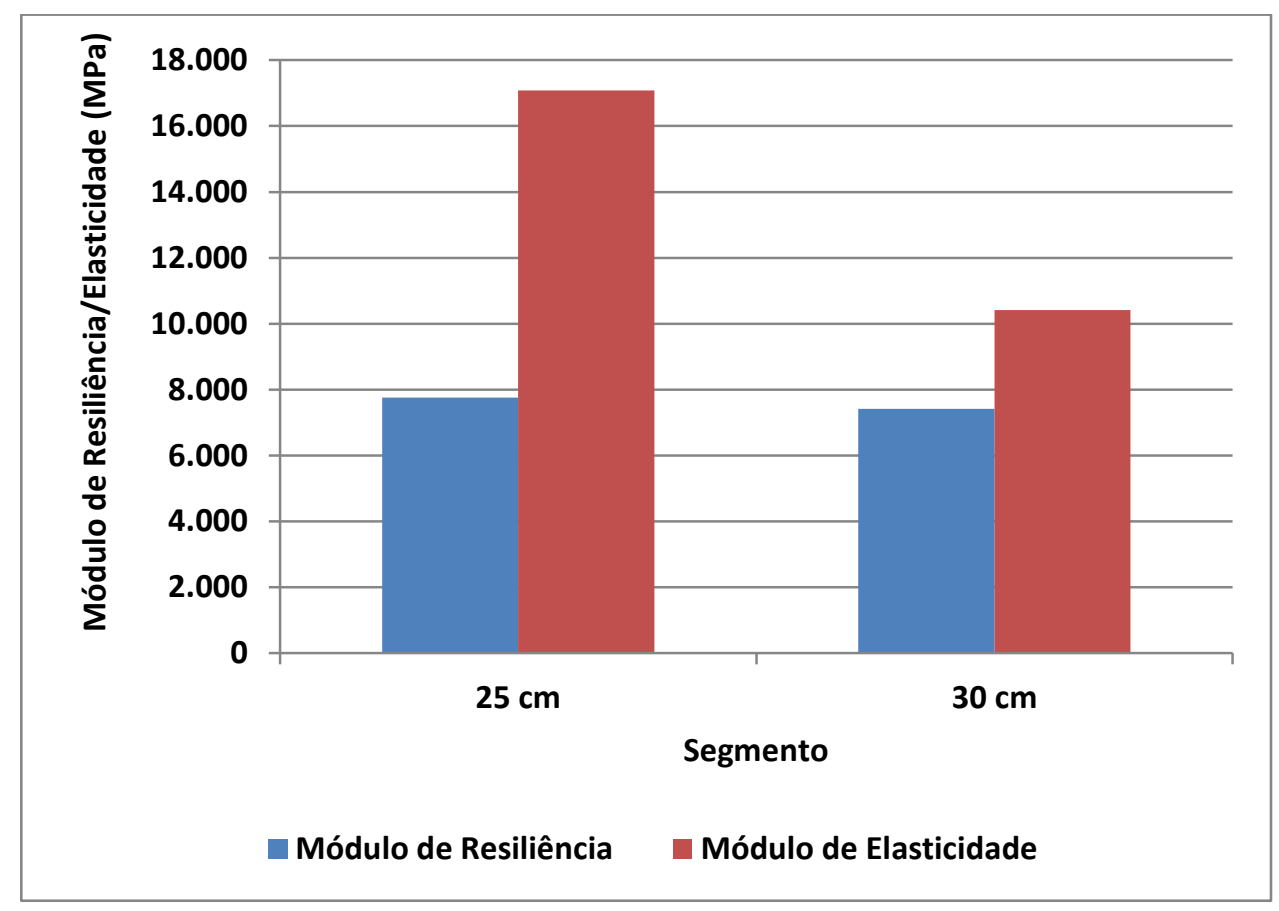

Figura 81 - Módulo de resiliência vs. módulo de elasticidade

Verifica-se que a variação dos módulos foi mais pronunciada nos corpos de prova da camada de $25 \mathrm{~cm}$. Conforme comentado, os módulos de elasticidade nessa camada 
foram mais elevados que os da camada de $30 \mathrm{~cm}$. O equipamento de módulo de resiliência apresenta uma limitação de medidas para materiais muito rígidos comprometendo suas medidas. Segundo o fabricante, o módulo de resiliência máximo que pode ser medido é de $12000 \mathrm{MPa}$, sendo esse valor inferior ao módulo de elasticidade de 17000 para a camada de $25 \mathrm{~cm}$ o equipamento pode não ter sido capaz de realizar as leituras de forma correta.

\subsubsection{Resistência à Compressão Simples}

Com o objetivo de melhor compreender os efeitos da eficiência de compactação, foram analisadas às tensões de ruptura à compressão obtidas no ensaio de módulo de elasticidade das amostras de campo. Os resultados obtidos são apresentados na Tabela 18.

Tabela 18 - Resultados de ensaio de resistência à compressão

\begin{tabular}{|c|c|c|c|c|}
\hline $\begin{array}{c}\text { Espessura da } \\
\text { Camada }\end{array}$ & Posição & $\begin{array}{c}\text { Número de } \\
\text { Amostras }\end{array}$ & $\mathbf{R C}$ (MPa) & $\begin{array}{c}\text { Desvio } \\
\text { Padrão (MPa) }\end{array}$ \\
\hline \multirow{2}{*}{$20 \mathrm{~cm}$} & Eixo & 1 & 7,71 & - \\
\cline { 2 - 5 } & Trilha Externa & - & - & - \\
\hline \multirow{2}{*}{$25 \mathrm{~cm}$} & Eixo & 3 & 8,79 & 0,76 \\
\cline { 2 - 5 } & Trilha Externa & 3 & 18,79 & 2,75 \\
\hline \multirow{2}{*}{$30 \mathrm{~cm}$} & Eixo & 5 & 7,96 & 2,22 \\
\cline { 2 - 5 } & Trilha Externa & 2 & 10,28 & 0,57 \\
\hline
\end{tabular}

Assim como os resultados de módulo de elasticidade, foi possível identificar melhores resultados para a camada compactada com $25 \mathrm{~cm}$ de espessura tanto para amostras do eixo quanto para amostras da trilha externa, indicando que essa camada está melhor compactada. Foi possível identificar, também, os efeitos da consolidação das camadas cimentadas, onde os resultados obtidos para amostras da trilha externa são maiores que os obtidos para amostras do eixo. 


\section{CONSIDERAÇÕES FINAIS}

\subsection{CONCLUSÕES}

Diante dos dados obtidos para os ensaios realizados em laboratório, algumas conclusões podem ser tecidas, conforme abordado nos parágrafos a seguir:

- Os resultados de resistência à tração e resistência à compressão apresentaram sensibilidade ao método de ensaio utilizado. Verificou-se que os ensaios com aplicação de carga lenta levam a menores valores de resistência à tração e à compressão e menores deformações. Além disso, as diferenças na deformação foram mais pronunciadas em amostras com 7 dias de cura. Os ensaios de módulo de resiliência e módulo de elasticidade apresentaram valores distintos, devido principalmente às características pertinentes a cada um dos métodos de ensaio, como forma e amplitude de carregamento. A instrumentação do ensaio de módulo de resiliência não apresentou sensibilidade compatível com a elevada rigidez do material, comprometendo tais resultados.

- Verificaram-se diferenças entre o comportamento mecânico de materiais cimentados quando variados a distribuição granulométrica e o tipo de solo presentes na mistura. O Material 1, composto por $60 \%$ de brita e $5 \%$ de cimento, apresentou valores de resistência superiores ao Material 2, composto por $40 \%$ de brita e $6 \%$ de cimento, mantidas as demais condições.

- Observou-se um ganho de resistência à tração com o aumento no teor de cimento das misturas recicladas. Esse ganho está relacionado não só ao teor de cimento, mas também à diminuição da relação água/cimento e a redução do volume de vazios que ela acarreta. Os resultados de resistência à compressão, porém, apresentaram uma queda para o teor de 7\% de cimento (nos dois tempos de cura avaliados). Acredita-se que reações álcali-agregado possam ter causado essa redução. $O$ ensaio de módulo de resiliência não apresentou sensibilidade à variação do teor de cimento, devido à elevada variabilidade dos resultados. 
- A variação da energia de compactação em laboratório não se mostrou significativa em termos de ganho de resistência à tração, porém se mostrou significativa em termos de resistência à compressão. Esses resultados podem ser explicados pela diferença de planos de aplicação de carga durante o ensaio em relação ao plano de compactação da amostra. No ensaio de resistência à compressão a aplicação de carga se dá no mesmo plano que a compactação, aumentando a influência da energia de compactação.

- Em relação ao tempo de cura do material reciclado com cimento, verificou-se que a avaliação dos parâmetros mecânicos em apenas três datas não define a forma detalhada da curva de ganho de resistência, principalmente nas primeiras idades do material. O formato dessa curva é dependente do tipo de material, de sua granulometria, do tipo de cimento utilizado e da relação água/cimento.

O trecho experimental foi acompanhado desde sua construção e suas condições estruturais foram avaliadas durante o período da pesquisa por aproximadamente um ano. $O$ estudo das condições estruturais foi realizado através de levantamentos não destrutivos em campo e de ensaios mecânicos realizados em amostras extraídas de pista. A seguir estão algumas conclusões obtidas desta análise:

- O primeiro levantamento deflectométrico, realizado após a execução da obra, apontou melhores resultados (menores deflexões) no trecho com camada cimentada de $25 \mathrm{~cm}$ de espessura, apesar da semelhança na bacia de deflexão média obtida para o segmento com $30 \mathrm{~cm}$ de base reciclada. $O$ segundo levantamento deflectométrico, realizado um ano após a abertura ao tráfego, apresentou melhoria na condição estrutural das camadas devido às condições climáticas favoráveis (período de estiagem) e à consolidação das camadas decorrente do tráfego. Além das baixas deflexões, o formato das bacias foi também um indicativo da elevada rigidez da estrutrura. Observou-se uma grande influência da infraestrutura remanescente na resposta estrutural do pavimento.

- Os resultados de módulo de resiliência e ultrassom dos corpos de prova de campo apresentaram baixa variabilidade entre os trechos com 25 e $30 \mathrm{~cm}$ de espessura de compactação (as amostras de $20 \mathrm{~cm}$ não puderam ser 
comparadas por limitação em suas dimensões). Os ensaios de módulo de elasticidade, porém, indicaram maior rigidez da camada compactada com $25 \mathrm{~cm}$ de espessura com relação à camada de $30 \mathrm{~cm}$. Essa tendência foi também observada para os ensaios de resistência à compressão simples dos corpos de prova (extraídos do eixo e do bordo da pista), bem como nos resultados de módulo retroanalisados.

\subsection{SUGESTÕES PARA PESQUISAS FUTURAS}

Buscando aprofundar os conhecimentos sobre as misturas que contém solo-brita recicladas e cimento, além de aprimorar métodos de ensaio, faz-se as seguintes sugestões:

- Aprofundar o estudo da relação água/cimento e sua influência nas propriedades mecânicas de misturas solo-brita-cimento, moldando corpos de prova em diferentes umidades de compactação.

- Estudar o ganho de resistência e rigidez em função do tempo para diferentes misturas de solo-brita-cimento, principalmente no que diz respeito à granulometria e à mineralogia do solo.

- Verificação da ocorrência de reações álcali-agregados para solos de diferentes mineralogias e diferentes percentuais e tipos de cimento.

- Analisar a influência da instrumentação nos ensaios de rigidez, principalmente no que diz respeito ao ensaio de módulo de resiliência triaxial com a utilização de LVDT's. 


\section{REFERÊNCIAS BIBLIOGRÁFICAS}

AASHTO. T 307 - Standard Method of Test for Determining the Resilient Modulus of Soils and Aggregate Materials. 2011.

ABNT. NBR 7182. Associação Brasileira de Normas Técnicas. Método de Ensaio. Solo: Ensaio de Compactação. 1986.

ABNT. NBR 15114. Associação Brasileira de Normas Técnicas. Resíduos sólidos da construção civil - Áreas de reciclagem - Diretrizes para projeto, implantação e operação. 2004.

ABNT. NBR 8522. Concreto - Determinação dos Módulos de Elasticidade e de Deformação e da Curva Tensão-Deformação. 2003.

AIO, D. A.; SILVA, J. P. N; MACHADO, A. F.; SEGANTINI, A. A. S. Estudo da Influência do Uso do Cimento ARI nas Propriedades do Solo-Cimento Auto Adensável. Workshop "Concreto: Durabilidade, Qualidade e Novas Tecnologias". 2004.

ARRA. Asphalt Reclaiming and Recycling Association - Basic Asphalt Recycling Manual. 2001.

ASTM. American Society for Testing and Materials.ASTM D2166 - Standard Test Method for Unconfined Compressive Strength of Cohesive Soil. 2006.

ASTM. American Society for Testing and Materials.ASTM D6931 - Standard Test Method for Indirect Tensile (IDT) Strength of Bituminous Mixtures. 2007.

ASTM. American Society for Testing and Materials.ASTM, C496/C496M - 11 Standard Test Method for Splitting Tensile Strength of Cylindrical Concrete Specimens. 2011. 
ASTM. American Society for Testing and Materials. ASTM C39 - Standard Test Method for Compressive Strength of Cylindrical Concrete Specimens. 2012.

BALBO J.T. Estudo das Propriedades Mecânicas das Misturas de Brita e Cimento e sua Aplicação aos Pavimentos Semirrígidos. 1993.

BALBO J.T. Materiais Estabilizados com Aglomerantes Hidráulicos para Pavimentos de Concreto de Cimento Portland. Curso de Especialização para Projetista de Pavimento de Concreto - ABCP. 2002.

BALBO J.T. Britas graduadas tratadas com cimento: uma avaliação de sua durabilidade sob o enfoque de porosidade, tenacidade e fratura. Transportes. 2006.

BALBO J.T. Pavimentação Asfáltica: materiais, projeto e restauração. São Paulo: Oficina de Textos. 2007.

BEChARA, M.F., FURLAN, A. P., GIGANTE, A. C., FABBRI, G. T. P. Propriedades Mecânicas de Misturas Solos-Cimento com Solo Laterítico e Solo Não Laterítico. ANPET. 2010.

BERNUCCI, L. B.; MOTTA, L. M. G, CERATTI, J. A. P.; SOARES, J.B. Pavimentação Asfáltica: Formação básica para engenheiros. Rio de Janeiro. 2008.

BUCK, A D. Recycled Concrete as a source of aggregate. American Concrete Institute Journal. 1977.

CAMARGO, F., BENSON, C., EDIL, T. An Assessment of Resilient Modulus Testing: Internal and External Deflection Measurements. Geotechnical Testing Journal, Vol. 35, No. 6. 2012.

CASTRO, L. N. Reciclagem a frio "in situ" com espuma de asfalto. Dissertação de Mestrado, COPPE/ UFRJ, Rio de Janeiro. 2003. 
CERATTI, J. A. P. Estudo do Comportamento à Fadiga de Solos Estabilizados com Cimento para Utilização em Pavimentos. Tese (Doutorado), Universidade Federal do Rio de Janeiro, COPPE, Rio de Janeiro. 1991.

CERATTI, J. A. P.; CASANOVA. F. J.; Um método físico-químico para dosagem de solo-cimento. Simpósio sobre novos conceitos em ensaios de campo e laboratório em geotecnia. Anais. Rio de Janeiro. 1988.

CNT. Boletim Estatístico. 2006. Disponível em: < http://www.cnt.org.br/portal/img/arquivos/Boletim\%20Estatístico\%20CNT\%20\%202009.pdf >. Acesso em: 07/09/2009.

DAVICH, P., LABUZ, J., GUZINA, B., DRESCHER, A. Small strain and resilient modulus testing of granular soils. Report. Minnesota Department of Transportation. 2004.

DER/SP. Departamento de Estradas de Rodagem. DER/SP- ET-DE-P00/007A. Subbase ou base de solo-brita-cimento. 2006a.

DER/SP. Departamento de Estradas de Rodagem. DER/SP- ET-DE-P00/035A. Reciclagem de pavimento asfáltico in situ com cimento e brita. 2006b.

DNER. Departamento Nacional de Estradas de Rodagem. DNER-ME-196/98. Agregados - determinação do teor de umidade total, por secagem, em agregado graúdo.1998.

DNIT. Manual de Restauração de Pavimentos Asfálticos: Departamento Nacional de Infraestrutura de Transportes. 2006.

ENAMORADO, M., A. Estudo comparativo entre o método mecânico e o método físico-químico para dosagem de solo-cimento. Tese de Mestrado. COPPE/UFRJ. Rio de Janeiro. 1990. 
FIDELIS, R., Análise de dois solos modificados com cimento para dimensionamento de pavimentos. UFOP. Ouro Preto. 2011.

FRANÇA, F. C., Estabilização Química de solos para fins rodoviários: Estudo de caso com produto "RBI Grade 81". Dissertação de mestrado. Universidade Federal de Viçosa. Minas Gerais. 2003.

GODOY, H., Identificação e classificação geotécnica de latossolos do estado de São Paulo pelo método das pastilhas MCT. Tese de doutorado. Universidade Federal de São Paulo. 1997.

GREGÓRIO, J., Estabilização de um solo da formação Palermo com aditivo PZ Solution. (Trabalho de Conclusão de Curso). Universidade do Extremo Sul Catarinense - UNESC, Criciúma. 2010.

GUTHRIE W.S., SEBESTA S., SCULLION T. Selecting Optimum Cement Contents for Stabilizing Aggregate Base Materials. 2002.

IBRACON. Instituto Brasileiro de Concreto. Concreto: ensino, pesquisas e realizações. 2005.

JOHN, V. M., AGOPYAN, V. Reciclagem de resíduos da construção. Seminário Reciclagem de Resíduos Sólidos Domiciliares. 2000.

KANDHAL, P. S.; MALLICK, R.B. Aggregate tests for hot mix asphalt: state of the practice in North America. Proceedings, Canadian Technical Asphalt Association, Vol XLII. Novembro. 1997a.

KANDHAL, P. S.; MALLICK, R.B. Pavement Recycling Guidelines for State and Local Governments. FHWA. 1997b.

LIBERATORI, L. A.; CONSTANTINO, R. S.; JR., O. T. Cold in situ recycling - at SP147. A brand new experience. International symposium on Pavement recycling. São Paulo. 2005. 
MACEDO, M. M., Solos modificados com cimento - efeito no módulo de resiliência e no dimensionamento de pavimentos. Dissertação de mestrado. Universidade Federal de Pernambuco. Pernambuco. 2004.

MALLICK, R. B.; KANDHAL, P. S.; BRADBURY, R. L. Using Warm-Mix Asphalt Technology to Incorporate High Percentage of Reclaimed Asphalt Pavement Material in Asphalt Mixtures. Transportation Research Record, v. 2051. 2007.

MALLICK, R.B, BONNER, D. S. , BRADBURY, R. L., ANDREWS, J. O., KANDHAL, P.S., KEARNEY, E. J. Evaluation of Performance of Full-Depth Reclamation Mixes. Transportation Research Record, v. 1809. 2002.

MEHTA, P.K., MONTEIRO, P.J.M. Concreto: Microestrutura, Propriedades e Materiais. 3rd ed. São Paulo. 2008.

MERIGHI, J.V., FORTES, R.M. Estudo do aumento da resistência mecânica em função do tempo nas misturas de reciclagem com cimento Portland. IV Jornadas Luso-Brasileiras de Pavimentos. 2004.

MERIGHI, J.V., FORTES, R.M. Some aspects resistance's effect in the flexible pavements recycled with cement Portland. International symposium on pavement recycling. 2005.

MILLER H.J., AMATRUDO, M., KESTLER, M.A., GUTHRIE, W.S. Mechanistic Analysis of Reconstructed Roadways Incorporating Recycled Base Layers. TRB 2011 Annual Meeting. 2011.

MILLER, H.J., GUTHRIE W.S., CRANE R.A., SMITH, B. Evaluation of cementstabilized full-depth-recycled base materials for frost and early traffic conditions. 2009. 
MILLER, H.J., GUTHRIE W.S., KESTLER M.A., CARBO, C. Cement Treatment of Frost-Susceptible New England Base Materials Blended with Reclaimed Asphalt Pavement. Cold Regions Engineering 2006 - ASCE. 2006.

MORAIS, Á. S. Estudo das características de resistência do solo-cimento plástico e aplicação em estacas moldadas in loco. Dissertação de Mestrado, Universidade Estadual Paulista. Ilha Solteira. 2002.

MOURA, E., BERNUCCI, L. L. B. Estudo dos deslocamentos verticais e horizontais em corpos de prova marshall em ensaios de módulo de resiliência e de resistência à tração. XVII ANPET - Congresso de Pesquisa e Ensino em Transporte. 2004.

NOGAMI. J. S., VILLIBOR, D.F. Identificação Expedita dos Grupos de Classificação MCT Para Solos Tropicais. X COBRAMSEF, Foz do Iguaçu. Anais. ABMS, São Paulo. Vol 4, p.1293-1300. 1994.

OLIVEIRA, P. C. A. Contribuição ao estudo da técnica de reciclagem profunda na recuperação de pavimentos flexíveis. Dissertação de Mestrado, Universidade Estadual de Campinas, Campinas. 2003.

PARENTE, E. B.; PARREIRA, A. B.; SOARES, J.B. Avaliação do Comportamento Mecânico de um Solo Laterítico e de Outro Não Laterítico Estabilizados com Cimento. In: XVI ANPET - Congresso de Pesquisa e Ensino em Transportes, Panorama Nacional de Pesquisa em Transportes, v. 1. p. 95-107. 2002.

PCA. Full-Depth Reclamation with Cement. 2012. Disponível em: http://www.cement.org/pavements/pv_sc_fdr.asp. Acesso em 28/08/2012.

PESSOA, F. H. C., Análise dos solos urucus para fins de uso rodoviário. Dissertação de Mestrado, Departamento de Engenharia Civil e Ambiental, UnB, Brasília, DF. 2004.

PINTO, C. S., Curso Básico de Mecânica dos Solos. Oficina de Textos. 3" Edição. 2007. 
PMSP. Prefeitura Municipal de São Paulo - Lei n. 14.015 - Dispõe sobre o descarte e reciclagem de misturas asfálticas retiradas dos pavimentos urbanos municipais. 2005.

SALOMON, A. E NEWCOMB, D.E. Cold In-Place Recycling Literature Review and Preliminary Mixture Design Procedure. Minessota Department of Transportation, Relatório No. MN/RC-2000-21. 2000.

SANTOS, A. G. B. Bases Granulares de Agregados Reciclados. DISSERTAÇÃO DE MESTRADO. Universidade de Aveiro. Departamento de Engenharia Civil. 2009.

SCHIMMOLLER, V. E. , HOLTZ, K., EIGHMY, T. T., WILES, C. , SMITH, M., MALASHESKIE, G., ROHRBACH, G. J., SCHAFTLEIN, S., HELMS, G., CAMPBELL, R. D., VAN, C. H., DEUSEN, FORD, B. , ALMBORG, J. A (FHWA). Recycled Materials in European Highway Environments: Uses, Technologies, and Policies FHWA-PL-00-025. 2000.

SeVeri, A. A., BAlbo, J.T. ROdolfo, P.R., Sestini, V. M., PRieto, V. Verificação à Fadiga de Revestimentos Asfálticos e Bases Cimentadas "Programa Pavimentos Asfálticos v. 1.0". DER. 1999.

SILVA, J.J.R., ANDRADE, T., PIRES, T.A.C., DUARTE, D.C.L., RIOS, F., ROLIM, T.L., ALMEIDA, P.M. NETO, J.M.C., Possíveis fontes de incerteza associadas ao ensaio de resistência à compressão em corpos de prova cilíndricos de concreto. METROSUL IV - IV Congresso Latino-Americano de Metrologia, Foz do Iguaçu. 2004.

SPECHT L.P. Comportamento de Misturas de Solo-Cimento-Fibra Submetidas a Carregamentos Estáticos e Dinâmicos. Dissertação de Mestrado Universidade Federal do Rio Grande do Sul, Rio Grande do Sul. 2002. 
SUZUKI, C. Y., Contribuição ao estudo de pavimentos rodoviários com estrutura invertida (sub-base cimentada). Tese de Doutorado, Escola Politécnica da USP, São Paulo. 1992.

TRICHÊS, G., SANTOS, A. Avaliação do desempenho as reciclagem do pavimento da rodovia SC 303. CBR \& C BRASVIAS. Foz o Iguaçu. 2011

TUCHUMANTEL, JR. OSVALDO, Reciclagem de Pavimentos - Conceitos, Interpretações e Controle, Betunel Indústria e Comércio LTDA, pp. 7 a 10. 1999.

USAF. Air Force Manual № 32-1019. Soil Stabilization for Pavements. Unified Facilities Criteria (UFC). Department of the Army and the Air Force, Washington, DC. 1994.

VIEIRA, J. P., Interação Cimento Superplastificante: Avaliação da estabilidade do comportamento. Dissertação de mestrado. Universidade Técnica de Lisboa, Lisboa. 2010.

WANG, L., Cementitious Stabilization of soils in the presence of sulfate. Department of Civil \& Environmental Engineering (Thesis). Wuhan University of Technology. Louisiana. 2002.

WIRTGEN, Manual Wirtgen de Reciclagem a Frio - Windhagen, Alemanha. 1998.

YODER, E.; WITCZAK, M. Principles of pavement design. 2a. Edição: John Willey \& Sons, New York. 1975. 